\title{
AVALIAÇÃO DA DEGRADAÇÃO E TOXICIDADE DE FORMALDEÍDO EM REATOR ANAERÓBIO HORIZONTAL DE LEITO FIXO
}

Sonia Valle Walter Borges de Oliveira

Dissertação apresentada à Escola de Engenharia de São Carlos da Universidade de São Paulo, como parte dos requisitos para obtenção do título de Mestre em Hidráulica e Saneamento.

ORIENTADOR: Prof. Dr. Marcelo Zaiat 
"Disse também Deus:

As águas que estão debaixo do céu, ajuntem-se num mesmo lugar, e o elemento árido apareça. E assim se fez. E chamou Deus ao elemento árido, terra, e ao agregado das águas, mares”.

(Gênesis, 1: 9-10) 
Dedico este trabalho aos meus pais Wolfgang e Maria Luiza, aos meus sogros D.Norma e Sr.Borges, ao Marcio, meu eterno companheiro, e às minhas filhas Victória, Marília e Patrícia, por toda compreensão e incentivo. 


\section{AGRADECIMENTOS}

Ao Prof. Dr. Marcelo Zaiat pela orientação valiosa, sugestões e discussões imprescindíveis, disponibilidade e, antes de tudo, por ter acreditado neste trabalho.

À Profa. Elisabeth Moraes e à Quim.Maria Angela Tallarico Adorno pelo auxílio na execução experimental, sugestões, aulas de química, análises, importantes discussões sobre as rotas de degradação e acolhedora companhia.

À Bióloga Maria Bernadete Varesche pelas análises microbiológicas, bem como pelas orientações e discussões nessa área.

À grande amiga e colega Eng ${ }^{\mathrm{a}}$. Selma Cubas por toda a ajuda, sugestões, discussões e companhia.

Aos meus colegas e amigos Eng ${ }^{a}$. Kenia Mara da Rocha, Eng ${ }^{0}$.Rogers Ribeiro, Eng ${ }^{0}$.Valmir de Morais pela troca de experiências, sugestões e grande companheirismo.

Aos professores Wolfgang F. Walter, Maria Luiza V.Walter e Márcio M.B.de Oliveira, pelas discussões de química, matemática, informática e metodologia de pesquisa.

À Profa. Dra. Débora Terezia Balogh do Departamento de Física da EESC, por ter cedido o reagente para as análises de formaldeído.

À Faculdade de Medicina de Ribeirão Preto, em especial ao Departamento de Patologia , Laboratório Multidisciplinar e CEMEL, pela colaboração, fornecimento de dados e amostras.

À Prefeitura do Campus Administrativo de Ribeirão Preto pelo fornecimento de dados do Campus e ao Prefeito Prof. Dr. Moacyr Antonio Mestriner pelo grande incentivo.

Às Bibliotecas da EESC e do Campus de Ribeirão Preto pela colaboração incansável na busca de artigos.

Ao Laboratório de Resíduos Químicos do Campus de São Carlos pelo apoio da Dra. Leny Borghesan A. Alberguini e recolhimento dos resíduos gerados nesse trabalho.

A todos os professores, funcionários e demais colegas do SHS-EESC-USP que participaram, incentivaram e auxiliaram para que fosse possível a realização deste trabalho.

À CAPES pela bolsa de mestrado e à FAPESP pelo apoio financeiro. 


\section{SUMÁRIO}

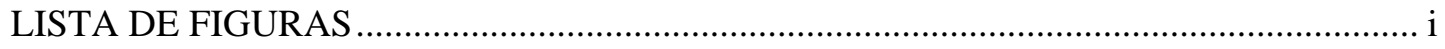

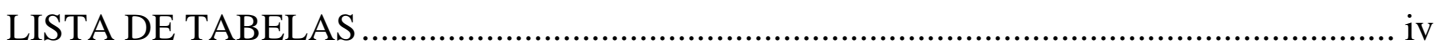

LISTA DE ABREVIATURAS E SIGLAS....................................................................... vi

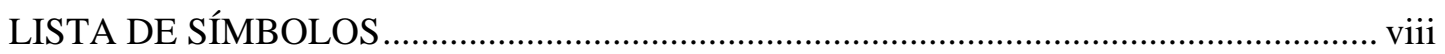

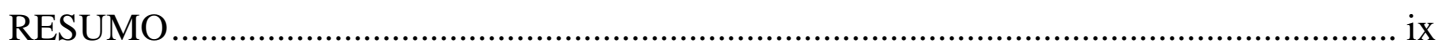

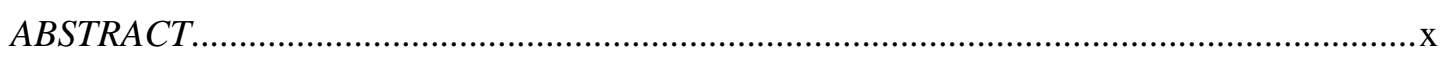

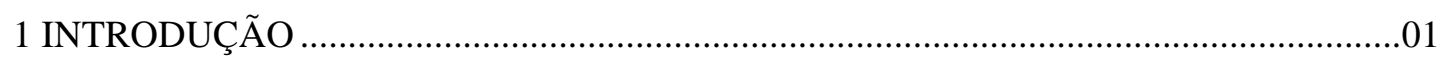

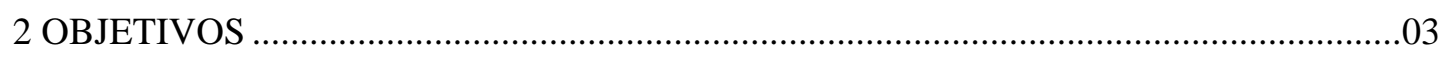

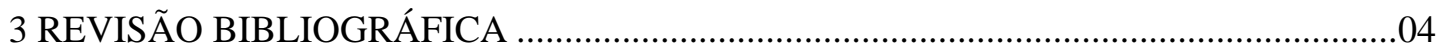

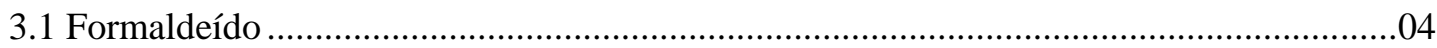

3.2 Tecnologias Anaeróbias para Degradação de Formaldeído ...............................................06

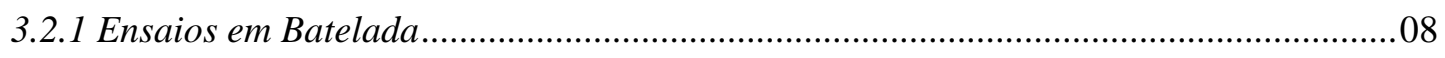

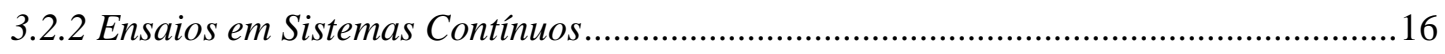

3.3 Reator Anaeróbio Horizontal de Leito Fixo …..............................................................21

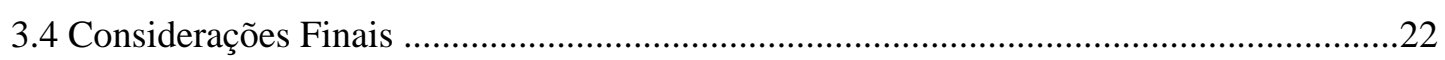

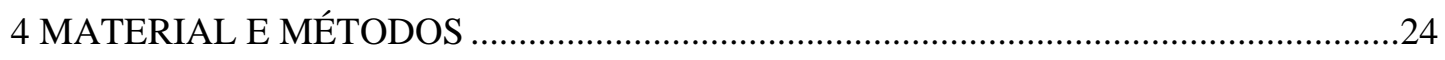

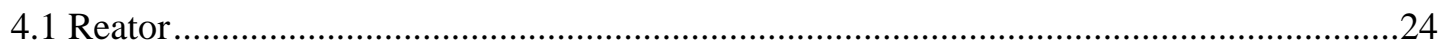

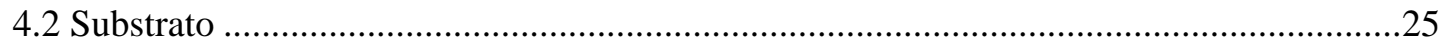

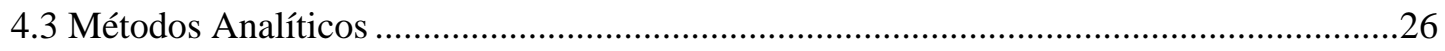

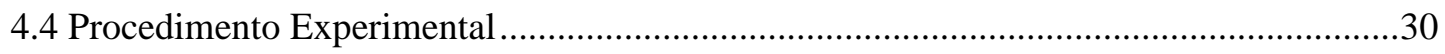

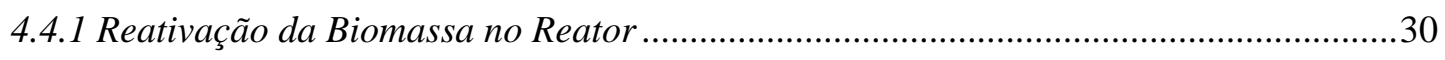

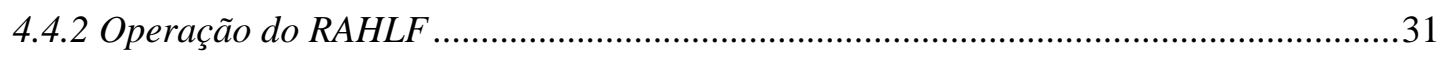

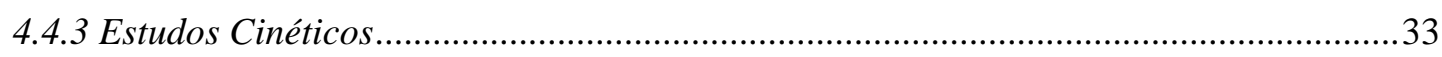

4.4.4 Destino Final do Efluente do Reator e Resíduos de Análises .........................................34

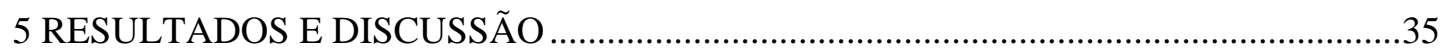

5.1 Ensaio de Degradabilidade do Substrato no Frasco de Alimentação...................................35

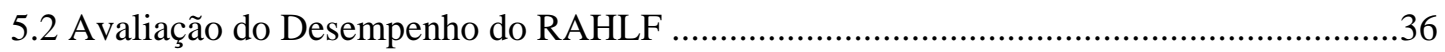

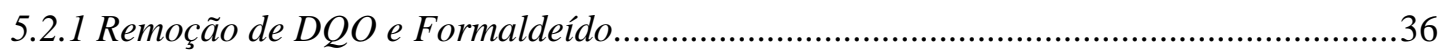

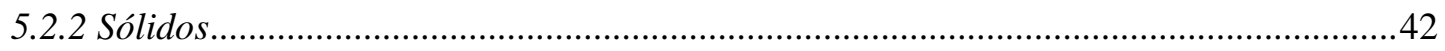


5.2.3 Alcalinidade e $\mathrm{pH}$

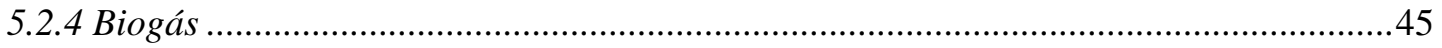

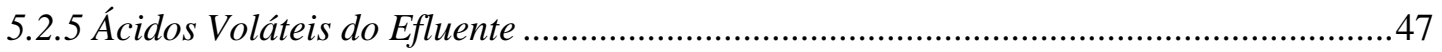

5.2.6 Considerações Sobre o Desempenho do RAHLF Tratando Formaldeído ........................48

5.3 Variação Espacial de Formaldeído e Outros Compostos ao Longo do RAHLF................49

5.3.1 Variação Espacial da Concentração de Formaldeído........................................................49

5.3.2 Variação Espacial de Outros Compostos ........................................................................54

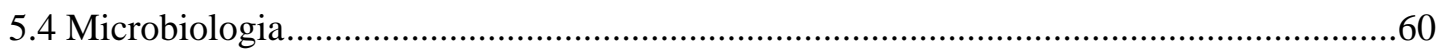

5.5 Estudo Comparativo dos Resultados do RAHLF com os da Literatura.............................69

5.6 Estimativa dos Parâmetros Cinéticos de Degradação de Formaldeído ................................73

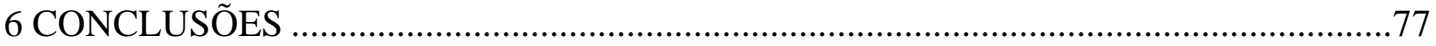

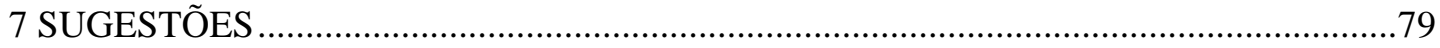

ANEXO - Estudo de Caso: Utilização de Formaldeído no Campus da USP de Ribeirão

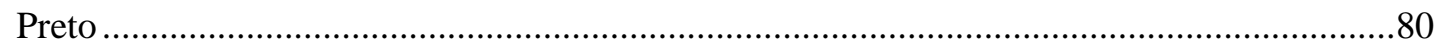

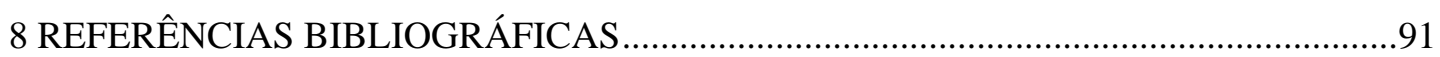




\section{LISTA DE FIGURAS}

FIGURA 4.1 - Esquema de reator anaeróbio horizontal de leito fixo.

FIGURA 4.2 - Curva de calibração para determinação da concentração de formaldeído pelo método de (BAILEY E RANKIN, 1971) ..................................................28

FIGURA 4.3 - Situação do lodo do RAHLF após cerca de três meses sem alimentação .......30

FIGURA 4.4 - Situação do lodo do RAHLF após 20 dias de reativação, com substrato à base de formaldeído. .31

FIGURA 5.1 - Variação temporal da concentração efluente de DQO (घ) e formaldeído (•).37

FIGURA 5.2 - Variação temporal da eficiência de remoção de DQO (ロ) e de formaldeído $(\bullet)$........................................................................... 38

FIGURA 5.3 - Variação temporal da relação mg DQO/mg formaldeído afluente (•) e efluente(ロ) .39

FIGURA 5.4 - Variação temporal da carga orgânica de DQO removida em função da carga orgânica aplicada

FIGURA 5.5 - Variação temporal da carga orgânica de formaldeído removida em função da carga orgânica aplicada .40

FIGURA 5.6 - Variação temporal das concentrações de sólidos totais (ロ) e sólidos voláteis totais ( $\bullet$ ) do efluente. .43

FIGURA 5.7 - Variação temporal das concentrações de sólidos suspensos totais (ם) e sólidos suspensos voláteis ( $\bullet$ ) do efluente.

FIGURA 5.8 - Variação temporal da concentração de alcalinidade total ( • ) e parcial ( $\bullet$ ) do afluente e total $(\diamond)$ e parcial $(\bigcirc)$ do efluente.

FIGURA 5.9 - Variação temporal da relação alcalinidade intermediária/alcalinidade parcial do efluente ( $\mathbf{\Delta}$ ).

FIGURA 5.10 - Variação temporal da concentração de $\mathrm{CH}_{4}(\boldsymbol{\Delta})$ e $\mathrm{CO}_{2}(\bullet)$.........................46

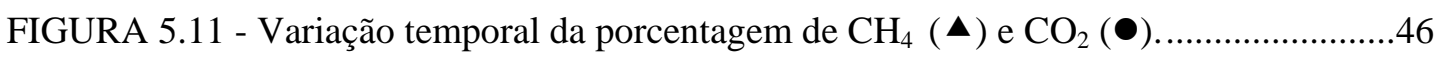

FIGURA 5.12 - Variação espacial da concentração de formaldeído para o

experimento com 26,2 mg/l de formaldeído afluente. 50 
FIGURA 5.13 - Variação espacial da concentração de formaldeído para o experimento com 85,3 mg/l de formaldeído afluente. 50

FIGURA 5.14 - Variação espacial da concentração de formaldeído para o experimento com 175,9 mg/l de formaldeído afluente. 50

FIGURA 5.15 - Variação espacial da concentração de formaldeído para o experimento com 394,0 mg/l de formaldeído afluente. 51

FIGURA 5.16 - Variação espacial da concentração de formaldeído para o experimento com 597,7 mg/l de formaldeído afluente. 51

FIGURA 5.17 - Variação espacial da concentração de formaldeído para o experimento com 808,0 mg/l de formaldeído afluente. 51

FIGURA 5.18 - Variação espacial da concentração de formaldeído para o experimento com 989,2 mg/l de formaldeído afluente. 52

FIGURA 5.19 - Variação espacial da concentração de formaldeído para o experimento com 1158,6 mg/l de formaldeído afluente. 52

FIGURA 5.20 - Variação espacial da concentração de formaldeído para o experimento com 1416,8 mg/l de formaldeído afluente. 52

FIGURA 5.21 - Variação da concentração de ácido acético em L/D=4 para experimentos com concentração afluente de formaldeído de 175,9 a $1158,6 \mathrm{mg} / \mathrm{L}$ 55

FIGURA 5.22 - Variação da concentração de ácido propiônico em L/D=4 para experimentos com concentração afluente de formaldeído de 175,9 a $1158,6 \mathrm{mg} / \mathrm{L}$ 56 
FIGURA 5.23 - Variação da concentração de ácido isobutírico em L/D=4 para experimentos com concentração afluente de formaldeído de 175,9 a $1158,6 \mathrm{mg} / \mathrm{L}$ 56

FIGURA 5.24 - Variação da concentração de ácido acético em L/D=8 para experimentos com concentração afluente de formaldeído de 175,9 a $1158,6 \mathrm{mg} / \mathrm{L}$ 56

FIGURA 5.25 - Variação da concentração de ácido propiônico em L/D=8 para experimentos com concentração afluente de formaldeído de 175,9 a $1158,6 \mathrm{mg} / \mathrm{L}$ 57

FIGURA 5.26 - Variação da concentração de ácido isobutírico em L/D=8 para experimentos com concentração afluente de formaldeído de 175,9 a $1158,6 \mathrm{mg} / \mathrm{L}$ 57

FIGURA 5.27 - Observações morfológicas sob microscopia de contraste de fase referentes à amostra do inóculo: Methanosaeta sp.e filamento fino (a); bacilo com extremidade arredondada e bacilo curvo (b) .60

FIGURA 5.28 - Observações morfológicas sob microscopia de contraste de fase referentes à amostra de 175,9 mg/L de formaldeído afluente médio: bacilo reto e bacilo curvo (a); Methanosaeta sp (b); filamento septado (c); bacilo com extremidades afiladas, Methanosaeta sp e bacilo com extremidades arredondadas (d). 61

FIGURA 5.29 - Observações morfológicas sob microscopia de contraste de fase referentes à amostra de 394,0 mg/L de formaldeído afluente médio: bacilo curvo e Methanosarcina sp. (a); bacilos com extremidades arredondadas e Methanosaeta sp (b); Methanosaeta sp (c); filamento fino e bacilos (d). ....62

FIGURA 5.30 - Observações morfológicas sob microscopia de contraste de fase referentes à amostra de 597,7 mg/L de formaldeído afluente médio: Methanosaeta sp. e bacilos com extremidades arredondadas (a); esporos de fungos (b); cocos (c); Methanosaeta sp. e bacilos com extremidades arredondadas (d); bacilo curvo (e); Methanosarcina sp. (f). 
FIGURA 5.31 - Observações morfológicas sob microscopia de contraste de fase referentes à amostra de 808,0 mg/L de formaldeído afluente médio: Methanosaeta sp.(a); bacilo esporulado e bacilo com extremidades arredondadas (b); esporos de fungos e bacilos (c); Methanosarcina sp.(d); bacilo com extremidade afilada e bacilo curvo 2 (e); fungos e esporos de fungos (f).

FIGURA 5.32 - Observações morfológicas sob microscopia de contraste de fase referentes à amostra de 989,2 mg/L de formaldeído afluente médio:.filamento fino (a); Methanosaeta sp. (b); Methanosarcina sp. (c); Methanosarcina sp.(d); esporos de fungos (e); bacilo esporulado (f).

FIGURA 5.33 - Observações morfológicas sob microscopia de contraste de fase referentes à amostra de 1158,6 mg/L de formaldeído afluente médio:.bacilo com extremidades afiladas e bacilo esporulado (a); bacilos (b); bacilo com extremidades afiladas, cocos e bacilo esporulado (c) e Methanosaeta sp.(d).

FIGURA 5.34 - Fungo observado na porção inicial do RAHLF durante os experimentos com concentrações médias de 597,7 a 808,0 mg/L de formaldeído afluente. ......69

FIGURA 5.35 - Ajuste de expressão cinética de $\operatorname{Monod}(-)$ aos pontos experimentais(•) ...75

FIGURA A1 - Vista geral da sala da cubas de cadáveres da FMRP. ……….........................83

FIGURA A2 - Peças fixadas em formol em caixas de vidro - sala de cubas da FMRP.......83

FIGURA A3 - Tanques com peças fixadas em formol - Departamento de PatologiaFMRP .84

FIGURA A4 - Representação esquemática de sistema de tratamento de efluente de fixação de cadáveres, à base de formaldeído, com RAHLF. .88 


\section{LISTA DE TABELAS}

TABELA 3.1 - Reações envolvendo a degradação anaeróbia de formaldeído de acordo com os relatos de OMIL et al. (1999) ..................................................................12

TABELA 4.1 - Composição do Meio Angelidaki (ANGELIDAKI et al, 1990) .....................26

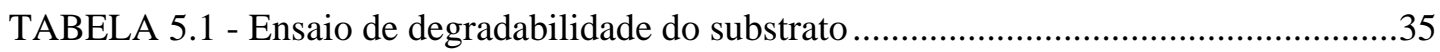

TABELA 5.2 - Concentrações médias de formaldeído afluente e efluente, com desvio padrão e número de amostras, durante o período de operação .36

TABELA 5.3 - Concentrações médias de DQO afluente e efluente, com desvio padrão e número de amostras, e relação média de DQO/formaldeído do efluente durante o período de operação .37

TABELA 5.4 - Comparação entre as cargas orgânicas de formaldeído aplicadas em alguns trabalhos com sistemas contínuos

TABELA 5.5 - Variação temporal média do conteúdo de $\mathrm{CH}_{4}$ no biogás em porcentagem e em $\mathrm{mol} / \mathrm{L}$.

TABELA 5.6 - Variação espacial da concentração de formaldeído no RAHLF para concentrações afluentes de formaldeído variando de 23,0 a 1378,0 $\mathrm{mg} / \mathrm{L}$ obtidas nas posições L/D iguais a 0 (entrada do reator), 4,8,12,16 e 20 (efluente).

TABELA 5.7 - Variação espacial da concentração de ácidos voláteis no RAHLF para concentrações afluentes de formaldeído variando de 175,9 a 1156,6 mg/L obtidas nas posições L/D iguais a 4 e 8 (N.D.=Não detectado).54

TABELA 5.8 - Variação espacial da concentração de ácidos lático, fórmico e acético para os experimentos com 1158,6 e 1416,8 mg/L de HCHO afluente.58

TABELA 5.9 - Morfologias dos microorganismos presentes na espuma de poliuretano do inóculo e ao longo dos experimentos com diferentes 
concentrações de formaldeído (++++ predominantes, +++ freqüentes, ++ pouco freqüentes, + raros, - não foram encontrados)................... 67

TABELA 5.10 - Resumo dos trabalhos com degradação anaeróbia de formaldeído com sistemas em batelada. ............................................................... 71

TABELA 5.11 - Resumo dos trabalhos com degradação anaeróbia de formaldeído em sistemas contínuos

TABELA 5.12 - Velocidades de reação em função da concentração de formaldeído aplicada ao reator anaeróbio horizontal. .74

TABELA A1 - Caracterização do líquido de preservação de cadáveres da FMRP .85 


\section{LISTA DE ABREVIATURAS E SIGLAS}

$\begin{array}{ll}\text { AT } & \text {-Alcalinidade Total } \\ \text { AVT } & \text {-Ácidos Voláteis Totais } \\ \text { BTEX } & \text {-Benzeno, Tolueno, Etilbenzeno e Xileno } \\ \text { CEMEL } & \text {-Centro de Medicina Legal } \\ \text { CO } & \text {-Carga Orgânica } \\ \text { CONAMA } & \text {-Conselho Nacional do Meio Ambiente } \\ \text { DNA } & \text {-Ácido Desoxirribonucléico } \\ \text { DQO } & \text {-Demanda Química de Oxigênio } \\ \text { EGSB } & \text {-Reator de Leito Granular Expandido } \\ \text { FMRP } & \text {-Faculdade de Medicina de Ribeirão Preto } \\ \text { FORP } & \text {-Faculdade de Odontologia de Ribeirão Preto } \\ \text { HAIS } & \text {-Horizontal-flow Anaerobic Immobilized Sludge } \\ \text { H.C. } & \text {-Hospital das Clínicas da FMRP } \\ \text { HCHO } & \text {-Formaldeído } \\ \text { HPLC } & \text {-Cromatografia Líquida de Alta Pressão } \\ \text { IUPAC } & \text {-International Union of Pure and Applied Chemistry } \\ \text { LRQ } & \text {-Laboratório de Resíduos Químicos } \\ \text { N.D. } & \text {-Não Detectado } \\ \text { P.A. } & \text {-Pureza Analítica } \\ \text { PCARP } & \text {-Prefeitura do Campus Administrativo de Ribeirão Preto } \\ \text { RAHLF } & \text {-Reator Anaeróbio Horizontal de Leito Fixo } \\ \text { RNA } & \text {-Ácido Ribonucléico } \\ \text { SST } & \text {-Sólidos Suspensos Totais } \\ \text { SSV } & \text {-Sólidos Suspensos Voláteis } \\ \text { ST } & \text {-Sólidos Totais } \\ \text { SV } & \text {-Sólidos Voláteis } \\ \text { TDH } & \text {-Tempo de Detenção Hidráulica } \\ \text { UASB } & \text {-Tempo de Retenção Celular } \\ \text {-Reator Anaeróbio de Manta de Lodo }\end{array}$




\section{LISTA DE SÍMBOLOS}

$\begin{array}{ll}\varepsilon & \text {-Porosidade do leito } \\ \mathrm{C}_{\mathrm{F}} & \text {-Concentração de formaldeído na fase líquida numa determinada posição } \\ & \text { longitudinal L/D. } \\ \mathrm{C}_{\mathrm{Fo}} & \text {-Concentração afluente de formaldeído } \\ \mathrm{D} & \text {-Diâmetro interno do reator } \\ \mathrm{IC}_{50} & \text {-Concentração do composto que causa } 50 \% \text { de inibição nos organismos } \\ \mathrm{K}_{\mathrm{S}}^{\text {app }} & \text {-Constante de saturação de substrato (aparente) } \\ \mathrm{L}_{\mathrm{L}} & \text {-Comprimento do reator } \\ \mathrm{LC}_{50} & \text {-Concentração do composto que causa a morte de 50\% dos organismos } \\ \mathrm{Q} & \text {-Vazão } \\ \mathrm{r}_{\text {max }} & \text {-Velocidade específica máxima de consumo de substrato (aparente) } \\ \mathrm{r}_{\mathrm{obs}} & \text {-Velocidade específica de utilização de substrato observada } \\ \mathrm{R}_{\mathrm{obs}} & \text {-Velocidade global de reação, } \\ \mathrm{S}_{0} & \text {-Concentração inicial de substrato } \\ \mathrm{V}_{\mathrm{S}} & \text {-Velocidade superficial de líquido } \\ \mathrm{X} & \text {-Concentração celular em relação ao volume líquido do sistema } \\ \mathrm{X}_{0} & \text {-Concentração inicial de biomassa }\end{array}$




\section{RESUMO}

OLIVEIRA, S.V.W.B. (2001). Avaliação da degradação e toxicidade de formaldeído em reator anaeróbio horizontal de leito fixo. São Carlos, 2001. 95 p. Dissertação (Mestrado) - Escola de Engenharia de São Carlos, Universidade de São Paulo.

Para minimizar os impactos ambientais causados pelo lançamento de formaldeído na natureza, é importante o desenvolvimento de tecnologias adequadas para o seu tratamento. Sistemas aeróbios têm sido utilizados, porém, as opções por tratamento anaeróbio estão tendo cada vez mais aceitação, principalmente pelo baixo consumo de energia e baixa produção de lodo. Por outro lado, substâncias tóxicas podem provocar distúrbios em reatores anaeróbios. Algumas pesquisas já foram desenvolvidas quanto ao tratamento biológico anaeróbio de formaldeído, no entanto, ainda não se chegou a um consenso sobre o seu comportamento ou qual o sistema mais eficaz. Nesse trabalho, avaliou-se a degradação e a toxicidade dessa substância em Reator Anaeróbio Horizontal de Leito Fixo, a fim de trazer subsídios para essa questão. As concentrações de estudo variaram de, aproximadamente, 30 a $1500 \mathrm{mg} / \mathrm{L}$ de formaldeído, atingindo-se as eficiências de remoção de até 99,7 \% de formaldeído e 92 \% de DQO. A presença de ácidos graxos com até cinco carbonos durante a degradação do formaldeído pode indicar uma rota de degradação diferente da sugerida na literatura, onde os produtos intermediários seriam o metanol e o ácido fórmico. O modelo cinético de Monod foi o que melhor representou os dados experimentais, com $r_{\max }^{a p p}=2,79 \mathrm{x}$ $10^{-3} \mathrm{mg} \mathrm{HCHO} / \mathrm{mg} \mathrm{SSV} . h$ e $\mathrm{K}_{\mathrm{S}}^{\mathrm{app}}=242,8 \mathrm{mg} \mathrm{HCHO} / \mathrm{L}$.

Palavras-chave: Formaldeído, tratamento anaeróbio de águas residuárias, toxicidade, reator anaeróbio horizontal de leito fixo. 


\begin{abstract}
OLIVEIRA, S.V.W.B. (2001). Evaluation of formaldehyde degradation and toxicity in horizontal-flow anaerobic immobilized sludge reactor. São Carlos, 2001. 95 p. Dissertação (Mestrado) - Escola de Engenharia de São Carlos, Universidade de São Paulo.
\end{abstract}

In order to minimize the environmental impacts caused by formaldehyde discharge in the nature, the development of appropriate technologies for its treatment is important. Aerobic systems have been used, however, anaerobic treatment options have been widely studied, mainly due to low energy consumption and sludge production. On the other hand, toxic substances can lead to disturbances in anaerobic reactors. Some formaldehyde anaerobic biological treatment researches have already been developed, although, there is no consensus about its behavior or which is the most efficient system. Degradation and toxicity of this substance were evaluated in Horizontal-Flow Anaerobic Immobilized Sludge Reactor, with the purpose of producing subsidies for this issue. Formaldehyde concentrations ranging from, approximately, 30 to $1500 \mathrm{mg} / \mathrm{L}$ were applied in the reactor and formaldehyde and COD removal efficiencies of $99,7 \%$ e $92 \%$ were achieved, respectively. Volatile fatty acids with up to 5 carbons, found during the formaldehyde degradation, can indicate that degradation followed different routes than those suggested in the literature, that reports the formation of intermediates such as methanol and formic acid. Monod kinetic model fitted well the experimental data, with apparent kinetic parameters estimated as $\mathrm{r}_{\max }^{\text {app }}=2,79 \times 10^{-3}$ mg HCHO/mg SSV.h and $\mathrm{K}_{\mathrm{S}}^{\mathrm{app}}=242,8 \mathrm{mg} \mathrm{HCHO} / \mathrm{L}$.

Key words: Formaldehyde, wastewater anaerobic treatment, toxicity, horizontal-flow anaerobic immobilized sludge reactor. 


\section{INTRODUÇÃO}

O formaldeído é utilizado industrialmente como componente de algumas resinas e colas, na indústria química e petroquímica, processamento têxtil, indústria de papel, processamento de madeira ou como ingrediente ativo de desinfetantes e conservantes. Neste caso, o formaldeído reage com DNA, RNA e proteínas, danificando as células, podendo causar a morte dos microorganismos (LU \& HEGEMANN, 1998). Na produção de formaldeído a partir de metanol, a água residuária gerada contém altas concentrações dessas duas substâncias: cerca 10 g/L e 20 g/L, respectivamente (ZOUTBERG \& DE BEEN, 1997). Na produção de resina de uréia-formaldeído, para indústrias de processamento de madeira, a concentração de formaldeído nas águas residuárias é de aproximadamente 2-4 g/L, com DQO em torno de $50 \mathrm{~g} / \mathrm{L}$ a $200 \mathrm{~g} / \mathrm{L}$ (LU \& HEGEMANN, 1998). A produção de dimetiltereftalato, utilizado na produção de fibras de poliéster, gera águas residuárias contendo $3 \mathrm{~g} / \mathrm{L}$ a 5 g/L de formaldeído (OMIL et al., 1999).

Segundo o ranking de impactos ambientais gerados por 45 produtos químicos, proposto por EDWARDS et al. (1999), o formaldeído ocupa o primeiro lugar. Foram utilizados dados de toxicidade de emissão no ar, água e solo para o ranqueamento. Segundo o MATERIAL SAFETY DATA SHEET (MSDS, 2000), o formaldeído é levemente tóxico para a vida aquática, sendo os valores do LC50/96 horas para peixes entre $10 \mathrm{mg} / \mathrm{L}$ e 100 $\mathrm{mg} / \mathrm{L}$.

Em escolas com cursos superiores e técnicos na área de saúde, o formaldeído é utilizado nos laboratórios ligados às áreas de anatomia e de patologia, como no Campus da USP de Ribeirão Preto (vide Apêndice A). Mesmo com as inúmeras pesquisas quanto à sua toxicidade (CASTEEL et al., 1987; GRAFSTROM et al., 1985; NOGUEIRA et al., 1997) alunos, docentes e técnicos de laboratório mantêm contato prolongado com formaldeído, sendo a substância mais utilizada na fixação de cadáveres e peças de anatomia. Grande parte dos laboratórios utiliza solução de formol a 10 \% em água de torneira (41 g/L de formaldeído), resultando em DQO de cerca de 62 g/L. Essa solução é descartada no esgoto de maneira diluída, durante o processo de lavagem das peças para aulas de anatomia, e concentrada, durante o escoamento dos tanques e recipientes para a troca do líquido, na 
manutenção e limpeza. Há estudos para se desenvolver novos fluidos para conservação de cadáveres com baixa concentração de formaldeído (COLEMAN \& KOGAN, 1998). No entanto, são adicionadas outras substâncias como cloreto de sódio (570 g/L) que podem ser menos prejudiciais à saúde humana, porém mais problemáticas para sistemas biológicos de tratamento de esgoto.

As pesquisas realizadas sobre a degradação e toxicidade de formaldeído em reatores anaeróbios foram desenvolvidas com base em efluentes industriais e seus resultados foram importantes no direcionamento deste trabalho. GONZALEZ-GIL (2000), entretanto, adverte que a literatura disponível sobre o assunto é de difícil interpretação, ainda insuficiente para fins de projeto e a maior parte das pesquisas foi desenvolvida com culturas adaptadas em meio contendo acetato, nas quais o impacto da capacidade de conversão do formaldeído de outros grupos de bactérias permanece indefinido.

Nas pesquisas relatadas na literatura, foram utilizados reatores em batelada, reatores de manta de lodo e escoamento ascendente (UASB), reatores de mistura contínuos e de leito granular expandido (Biobed ${ }^{\circledR}$ EGSB). Os meios utilizados apresentaram concentrações variando entre $30 \mathrm{mg} / \mathrm{L}$ e $3000 \mathrm{mg} / \mathrm{L}$ de formaldeído, com ou sem co-substrato, e os resultados de inibição da atividade microbiana são distintos. Também foram variados os modos de alimentação e aumento da concentração de formaldeído.

A rota de degradação anaeróbia do formaldeído ainda não está bem definida nos estudos, tampouco foram identificados, especificamente, os microorganismos que fazem parte da degradação. Em todos os trabalhos encontrados na literatura houve a preocupação em manter-se um alto tempo de retenção celular como item imprescindível para o bom desempenho do reator. Também houve a indicação de que os reatores de fluxo contínuo tiveram melhores resultados que os em batelada.

Considerando o problema ambiental causado por despejos contendo formaldeído e a potencialidade da biotecnologia anaeróbia para aplicação no tratamento de águas residuárias contendo tóxicos, este trabalho visa contribuir para esclarecer alguns aspectos fundamentais e tecnológicos da degradação de formaldeído utilizando processo anaeróbio contínuo. Para isso, foi escolhido o Reator Anaeróbio Horizontal de Leito Fixo (RAHLF ou HAIS Horizontal-flow Anaerobic Immobilized Sludge), com suporte de espuma de poliuretano, com o intuito de alcançar altas concentrações de biomassa. As concentrações médias de formaldeído utilizadas nos experimentos foram de 26,2, 85,3, 175,9, 394,0, 597,7, 808,0, 989,2, 1158,6 e 1416,8 mg/L, próximas às encontradas na literatura para a comparação dos resultados. 


\section{OBJETIVOS}

O principal objetivo deste trabalho foi avaliar o desempenho de reator anaeróbio de leito fixo no tratamento de despejo contendo formaldeído como única fonte de carbono. Para isso, um reator anaeróbio horizontal de leito fixo foi submetido a concentrações médias crescentes de formaldeído entre 26,2 mg/L e 1416,8 mg/L.

Os objetivos específicos deste projeto foram:

- Avaliação da toxicidade exercida pelo formaldeído sobre a biomassa anaeróbia, imobilizada em espuma de poliuretano;

- Determinação das velocidades de degradação de formaldeído, ajuste de modelo reacional e estimativa dos parâmetros cinéticos de degradação;

- Contribuição para a elucidação da rota de degradação do tóxico pela via anaeróbia;

- Avaliação da biomassa envolvida na degradação anaeróbia do formaldeído. 


\section{REVISÃO BIBLIOGRÁFICA}

\subsection{Formaldeído}

Formaldeído, HCHO, é o aldeído mais conhecido e usado. Também é chamado de aldeído fórmico, metanal ou metil aldeído. Pelas regras da IUPAC, deve ser chamado de metanal (PERUZZO \& CANTO, 1998). Em solução aquosa é denominado formol ou formalina, comercializado na porcentagem de 37 a $40 \%$ de formaldeído e 10 a $15 \%$ de metanol. O metanol é adicionado para a estabilização da solução, uma vez que aldeídos em meio aquoso tendem a se polimerizar (ALLINGER et al., 1978; VOGEL, 1971). Como polímero sólido é denominado paraformaldeído, contendo 91 \% a 99 \% de formaldeído.

Suas propriedades físico-químicas são (MSDS, 2000):

- Aparência: líquido claro e incolor

- Odor: penetrante

- Solubilidade em água: infinitamente solúvel

- Densidade (solução de formol): $1,081 \mathrm{~g} / \mathrm{cm}^{3}$

- Massa molecular: 30,03

- Ponto de ebulição: $96^{\circ} \mathrm{C}$

- Ponto de fusão: $-15^{\circ} \mathrm{C}$

- Volatilidade: $100 \%$

- $\mathrm{pH}: 2,8-4,0$

- Estabilidade: estável sob condições normais de uso e armazenamento

É produzido industrialmente por oxidação do metanol (FELTRE \& YOSHINAGA, 1977), como:

$$
\begin{aligned}
& \Delta \\
& 2 \mathrm{CH}_{3} \mathrm{OH}+\mathrm{O}_{2} \rightarrow 2 \mathrm{HCHO}+2 \mathrm{H}_{2} \mathrm{O} \\
& \text { Pt }
\end{aligned}
$$

Cobre metálico ou uma mistura de óxidos de ferro e molibdênio podem substituir a platina na catálise dessa reação. 
O formaldeído é um importante intermediário na síntese de compostos orgânicos e na indústria de plásticos e resinas utilizados na produção de derivados de madeira, como laminados e aglomerados. Muitos fertilizantes contêm produtos à base de uréia-formaldeído. Outros usos do formaldeído englobam: preparo de tintas e vernizes, na indústria de fibra de vidro, na produção de bakelite, de urotropina (hexametilenotetramina - anti-séptico das vias urinárias), parafórmio (desinfetante em pastilhas), tioximetileno (larvicida de mosquitos), solução hidro-alcoólica de sabão com formol, conhecida como Lysoform, e rongalite, na indústria têxtil. Na II Guerra Mundial foi utilizado como poderoso explosivo chamado ciclonita ou RDX, reagindo com ácido nítrico na presença de nitrato de amônio. Tem largo emprego na desinfecção de salas de cirurgia e outros ambientes hospitalares, pois uma solução a 0,5\% ( 5400 mg/L) destrói todas as espécies de microorganismos no prazo de 6 a 12 horas (MINGOIA, 1967).

Para a conservação de cadáveres e peças de anatomia, o formaldeído ainda é o principal soluto, por vezes o único, diluído de $8 \%$ a $10 \%$ em água. Esse composto impede a proliferação de microorganismos e, portanto, a putrefação, além de impedir o rompimento das paredes dos lisossomos, o que provocaria a autólise da célula pelas enzimas ali contidas (JUNQUEIRA \& CARNEIRO, 1995). Segundo informações dos técnicos de laboratório da Faculdade de Medicina de Ribeirão Preto (FMRP-USP), sua ação é duradoura, retardando a degradação, em relação à de peças não fixadas. No caso de embalsamamento de corpos, deverá ser lavrada uma ata sobre o fato, onde assinam as autoridades policiais, os médicos, o representante da família e testemunhas (CARVALHO, 1950).

A percepção de formaldeído pelo odor ou irritação dos olhos tende a ser menos intensa à medida que o indivíduo se adapta a essa substância. Isso pode levar a uma superexposição, pois o indivíduo pode perceber a presença do tóxico apenas em altas concentrações. Sua inalação pode causar irritação da garganta, tosse e falha na respiração. Concentrações de 25 ppm a 30 ppm causam danos severos no trato respiratório, levando a edema pulmonar e doenças pulmonares. Pode ser fatal em altas concentrações (MSDS, 2000).

A ingestão de formaldeído causa dor abdominal severa, vômitos violentos, dor de cabeça e diarréia. Doses altas podem produzir uma queda de temperatura, dor no trato digestivo, respiração fraca, pulso irregular e fraco, perda de consciência e morte (MSDS, 2000). Formaldeído também é tóxico em contato com a pele, podendo causar irritação, dor, vermelhidão e até queimaduras. A absorção pela pele pode causar os mesmos sintomas da ingestão (MSDS, 2000). Além disso, o metanol presente na formalina afeta o nervo ótico e pode causar cegueira. 
Estudos mostram que formaldeído pode causar mutação em células humanas, além de carcinogênese (GRAFSTROM et al., 1985). Pesquisas com ratos e camundongos demonstraram que a exposição crônica a altos níveis de formaldeído induzem a carcinomas nasais em cerca de 50\% dos animais (CASTEEL et al., 1986). Trabalhos mais recentes com ratos e macacos confirmam o poder cancerígeno do formaldeído (CONAWAY et al., 1996).

A emissão de formaldeído no meio ambiente pode ter graves conseqüências. Se depositado em solo, pode ser lixiviado para águas subterrâneas. Embora seja biodegradável, poderá ser tóxico para a vida aquática, uma vez que o LC50/96 horas para os peixes é de 10 mg/L a 100 mg/L. Para emissão no ar, a meia-vida é de menos de 1 dia (MSDS, 2000).

Portanto, águas residuárias contendo formaldeído apenas deverão ser lançadas no meio ambiente após tratamento prévio ou grande diluição, para que atinjam concentrações não prejudiciais.

QU \& BHATTACHARYA (1997) relatam que, em testes abióticos, em triplicata, para a remoção de formaldeído por sorção, volatilização ou transformação química, apenas $10 \%$ dos $30 \mathrm{mg} / \mathrm{L}$ de formaldeído foram removidos. Em testes bióticos, $26 \mathrm{mg} / \mathrm{l}$ foram removidos por cultura anaeróbia acetoclástica em frascos, indicando que a biodegradação é o principal mecanismo para remoção de formaldeído. Os autores consideram que a “degradação anaeróbia é uma alternativa para a degradação aeróbia na remoção de formaldeído de águas residuárias”.

SPEECE (1996) comenta que muitos tóxicos, incluindo formaldeído, são biodegradáveis somente em condições anaeróbias, quando perdem sua toxicidade.

A disposição do formaldeído pode prejudicar o desempenho de estações de tratamento de esgoto, devido ao seu poder antimicrobiano (QU \& BHATTACHARYA, 1997). Porém, os estudos feitos em diversos tipos de reatores e em diferentes concentrações e modos de operação, demonstraram ser possível sua degradação anaeróbia.

\subsection{Tecnologias Anaeróbias para Degradação de Formaldeído}

Alguns trabalhos citam a biodegradação aeróbia do formaldeído. Em estudos de cinética da biodegradação aeróbia, BONASTRE et al. (1985) utilizaram concentrações de $100 \mathrm{mg} / \mathrm{L}$ a $2300 \mathrm{mg} / \mathrm{L}$ de formaldeído, em lodos ativados, obtendo uma degradação de pelo menos 90\% em 120 horas para a concentração de 2100 mg/L. LEONOVA et al. (1985) também em estudos de cinética da degradação aeróbia de formaldeído, trabalharam com 
concentrações de $80 \mathrm{mg} / \mathrm{L}$ a $2000 \mathrm{mg} / \mathrm{L}$, observando forte inibição do processo com 600 mg/L. ADROER et al. (1990) avaliaram a biodegradação de formaldeído por Pseudomonas putida, isolada de um biorreator de leito fluidificado tratando formaldeído: $240 \mathrm{mg} / \mathrm{L}$ foram adicionados como única fonte de carbono, obtendo-se concentração efluente de $40 \mathrm{mg} / \mathrm{L}$ após 24 horas (remoção aproximada de 83\%). Nos estudos de GOTVAJN \& ZAGORCKONCAN (1998), em sistemas de lodos ativados, a concentração inicial de formaldeído de $100 \mathrm{mg} / \mathrm{L}$, foi degradada entre $80 \%$ a 97\%, em cerca de 5 dias. Embora tenham sido observados bons resultados de degradação de formaldeído em sistemas aeróbios, os custos com consumo de energia e disposição de lodo podem ser minimizados se as tecnologias anaeróbias forem empregadas.

Em relação à degradação anaeróbia, QU \& BHATTACHARYA (1997) ressaltam que "informações limitadas são encontradas na literatura sobre a degradação anaeróbia do formaldeído”. GONZALEZ-GIL (2000) alerta que ainda faltam conhecimentos sobre a cinética e os mecanismos dos compostos tóxicos em sistemas anaeróbios. Também não está claro, na literatura, se o formaldeído é convertido diretamente a metano ou se produtos de sua degradação são os verdadeiros substratos para a metanogênese (GONZALEZ-GIL, 2000).

Da mesma forma, não há consenso sobre a concentração inibidora de formaldeído, o sistema mais adequado, os produtos intermediários da degradação, os microorganismos responsáveis por cada estágio de degradação, e a importância de co-substrato.

Quanto à toxicidade, SPEECE (1996) comenta que o potencial de aclimatação da biomassa anaeróbia a muitos tóxicos pode ser realizada se o bom senso e a paciência forem empregados na exposição da biomassa, primeiramente a concentrações relativamente baixas, antes de aumentar-se as concentrações para a concentração máxima a ser aplicada. Esse procedimento cumprirá duas funções cruciais: a aclimatação da biomassa será desenvolvida sob condições favoráveis e a concentração de tóxicos biodegradáveis dentro do reator será mantida em um nível significativamente mais baixo que aquele da água residuária em questão. SPEECE (1996) também comenta que o formaldeído é um bom exemplo de composto que é muito tóxico em altas concentrações, mas prontamente biodegradável em concentrações mais baixas.

A seguir são apresentados os trabalhos realizados com degradação anaeróbia de formaldeído, de acordo com o tipo de sistema empregado. Os substratos são, em geral, efluentes de indústrias químicas ou de derivados de madeira com utilização de cola e resina a base de formaldeído. 
Quanto ao formaldeído utilizado na fixação de peças para anatomia, não foi encontrado nenhum trabalho específico sobre a degradação de seu efluente por processos biológicos. A composição do efluente de laboratórios de anatomia não possui concentrações constantes e contém sólidos como tecidos e musculatura fixados, que possivelmente terão difícil degradação. Também há gordura em pequenas quantidades, que deverá ser levada em conta durante o tratamento. Apenas um trabalho (TAKESUE et al., 1983) cita a preocupação com efluentes de hospital contendo formaldeído, por processo químico de decomposição, com hidróxido de cálcio.

Ao contrário da escassez de pesquisas na área citada, um grande volume de trabalhos sobre formaldeído concentra-se na preocupação com a saúde dos alunos, professores e principalmente técnicos de laboratório que constantemente utilizam peças de anatomia fixadas em formaldeído nas aulas práticas. NOGUEIRA et al. (1997) criaram uma câmara para trabalho com pequenos animais fixados em formaldeído, onde se diminui a inalação dessa substância durante os procedimentos cirúrgicos.

\subsubsection{Ensaios em Batelada}

PARKIN et al. (1983) efetuaram estudos com quatro tóxicos presentes em algumas águas residuárias industriais: níquel, amônio, sulfeto e formaldeído. Nos ensaios em batelada, foram utilizados frascos de soro com capacidade de $150 \mathrm{~mL}$. Foram empregados 50 $\mathrm{mL}$ de biomassa de estoque, proveniente de estação de tratamento municipal, previamente tratada com ácido acético como única fonte de carbono. Os experimentos foram efetuados à temperatura de $35^{\circ} \mathrm{C}$. O substrato foi constituído de acetato acrescido de solução de sais e metais e formaldeído nas concentrações de $100 \mathrm{mg} / \mathrm{L}, 150 \mathrm{mg} / \mathrm{L}, 250 \mathrm{mg} / \mathrm{L}$ e $500 \mathrm{mg} / \mathrm{L}$. Atrasos no início da produção de gás e decréscimos de sua produção foram observados à medida que a concentração de formaldeído era aumentada. Os autores concluíram que a dose limitante de formaldeído por toxicidade, nesse caso, foi de menos de $100 \mathrm{mg} / \mathrm{L}$.

No trabalho de HICKEY et al. (1987) também foram efetuados estudos de toxicidade de quatro tóxicos orgânicos: clorofórmio, ácido bromo-etanosulfônico, ácido tricloroacético e formaldeído. Foram utilizados frascos de soro de volume total de $160 \mathrm{~mL}$, contendo alíquotas de 5,0 mL de resíduo agitado de lodo ativado. Volumes de $95 \mathrm{~mL}$ de inóculo de lodo de digestor anaeróbio foram inseridos nos frascos, sob condições anaeróbias, e mantidos completamente misturados com agitador magnético. Os experimentos foram efetuados à temperatura de $35^{\circ} \mathrm{C} \pm 0,5^{\circ} \mathrm{C}$. Foram estudadas concentrações de formaldeído de 
$10 \mathrm{mg} / \mathrm{L}$ a $100 \mathrm{mg} / \mathrm{L}$. Os ensaios transcorreram em períodos de 24 horas. O restabelecimento da produção de metano foi observado para todas as doses, exceto para $100 \mathrm{mg} / \mathrm{L}$. O tempo necessário para o restabelecimento da produção de metano parece estar diretamente relacionado com a concentração do formaldeído. A inibição foi avaliada pelo acúmulo de hidrogênio e de ácidos voláteis: quanto maior a concentração de formaldeído, maior a concentração de $\mathrm{H}_{2}$. Os autores sugeriram que o monitoramento do hidrogênio pode ser um indicador mais rápido para distúrbios do processo, devidos a choques de tóxicos.

TODINI \& HULSHOFF POL (1992) estudaram a degradação de benzaldeído em lodo granular metanogênico, empregando formaldeído como composto de referência nos ensaios com co-substratos. Para os ensaios de toxicidade foram utilizados frascos de soro de vidro com $500 \mathrm{~mL}$, contendo lodo granular metanogênico proveniente de reator UASB em escala real tratando água residuária de indústria petroquímica (1 g SSV/L). Foram acrescentados sais minerais, elementos traço e sacarose na concentração de $3680 \mathrm{mg}$ DQO/L. O meio foi tamponado em pH 7,0. A concentração de formaldeído que causou inibição de 50\% ( $\left(\mathrm{IC}_{50}\right)$ foi de $254 \mathrm{mg}$ DQO/L. Em ensaios de $535 \mathrm{mg}$ DQO/L de formaldeído, morte celular começou a ser observada após uma semana.

QU \& BHATTACHARYA (1997) avaliaram a toxicidade e biodegradação de formaldeído em cultura metanogênica anaeróbia. Foram utilizados frascos de soro de 150 mL, com cultura acetoclástica não aclimatada (50 mL a $75 \mathrm{~mL}$ por frasco), em ensaios com baixa concentração de biomassa (SSV 220 mg/L a 360 mg/L) e alta concentração de biomassa (SSV 1000 mg/L). A alimentação foi feita com 500mg/L de ácido acético, diariamente por 4-7 dias, até que a variação da produção diária de gás fosse menor que 10\%, antes de adicionar-se o formaldeído. Os frascos foram incubados a $35^{\circ} \mathrm{C}$. Nos ensaios com baixa concentração de biomassa, $10 \mathrm{mg} / \mathrm{L}$ de formaldeído inibiram a utilização de acetato, e com 20 a 27 mg/L de formaldeído, o período de inibição foi mais longo, embora a degradação do formaldeído não apresentasse nenhuma fase lag. O comportamento da velocidade de degradação apresentou boa correlação com o modelo de Monod, diminuindo quando foram acrescentados $62 \mathrm{mg} / \mathrm{L}$. Os parâmetros cinéticos encontrados pelos pesquisadores foram: $\mathrm{k}$ (velocidade específica máxima) = 0,35-0,46 dia ${ }^{-1}$ e $\mathrm{K}_{\mathrm{s}}$ (constante de saturação) = 2,1-2,4 mg/L. Degradação parcial foi observada para a concentração de 95 mg/L de formaldeído.

Comparando-se os resultados dos ensaios com alta concentração de biomassa, pôde ser observado que mais formaldeído foi degradado nessas condições. Os autores concluíram que, para concentrações de formaldeído maiores que $60 \mathrm{mg} / \mathrm{L}$, a razão inicial de formaldeído por biomassa $\left(\mathrm{S}_{0} / \mathrm{X}_{0}\right)$ pode ser usada para estimar a porcentagem de degradação do 
formaldeído, sendo quase completa quando $\mathrm{S}_{0} / \mathrm{X}_{0}=0,10 \quad\left(\mathrm{~S}_{0}=95 \mathrm{mg} / \mathrm{L}\right)$. Quanto à aclimatação, os resultados mostraram que o formaldeído ainda causou severa inibição na utilização de acetato após aclimatação, ou seja, a cultura acetoclástica não se aclimatou em sistemas em batelada, com alimentação em doses repetidas (batelada alimentada repetida). Entretanto, a toxicidade pode ser evitada pela adição repetida de baixas concentrações de formaldeído, em sistemas em batelada.

LU \& HEGEMANN (1998) estudaram a degradação anaeróbia de águas residuárias sintética e real, contendo formaldeído. A sintética foi constituída de glicose (5,5 g/L) e formaldeído (concentrações de $0 \mathrm{mg} / \mathrm{L}$ a $3000 \mathrm{mg} / \mathrm{L}$ ), acrescida de nutrientes minerais e elementos traço. A real, à base de resina de uréia-formaldeído, foi diluída em meio contendo nutrientes minerais e elementos traço, para atingir as concentrações de 100, 200, 400 e 600 mg/L. A DQO dessa solução oscilou entre $6675 \mathrm{mg} / \mathrm{L}$ e $40050 \mathrm{mg} / \mathrm{L}$. As soluções foram tamponadas a pH igual a 7,0 com tampão de fosfato. O inóculo para os estudos foi uma mistura de lodo ativado da estação de tratamento de água residuária de uma indústria de processamento de madeira, contendo formaldeído e lodo de digestor anaeróbio de uma estação municipal de tratamento. Para os estudos em bataleda, foram utilizados frascos de vidro de $500 \mathrm{~mL}$ com diferentes concentrações de formaldeído (0 mg/L a $3000 \mathrm{mg} / \mathrm{L}$ ), contendo $100 \mathrm{~mL}$ de lodo e $300 \mathrm{~mL}$ de água residuária. Os frascos foram mantidos em banho de água, à temperatura de $35^{\circ} \mathrm{C}$, por 20 dias, sem realimentação. Nos ensaios com água residuária sintética, a maior produção de biogás foi obtida na concentração de $200 \mathrm{mg} / \mathrm{L}$, embora houvesse uma fase lag de 6 dias. Na concentração de 400 mg/L praticamente não houve mais produção de gás. Nos testes com água residuária real, para a concentração de 100 mg/L, após uma fase de 7 dias, houve apenas uma pequena produção de gás, porém no oitavo dia foi atingida a produção máxima, com valor próximo ao da concentração de 200 $\mathrm{mg} / \mathrm{L}$ da sintética. O padrão de queda da produção de gás também foi semelhante entre as duas águas residuárias, porém sendo na concentração de $200 \mathrm{mg} / \mathrm{L}$ para a real e $400 \mathrm{mg} / \mathrm{L}$ para a sintética.

Quanto à remoção de DQO, na sintética foi alcançado $70 \%$ na concentração de 10 mg/L de formaldeído e menos de 21,4\% para mais de $400 \mathrm{mg} / \mathrm{L}$, sendo quase nula para 3000 mg/L. Na real, a remoção atingiu 92,4\% para a concentração de 100 mg/L, caindo para 22,8\% na concentração de 200 mg/L e para cerca de 10\% em concentrações mais altas. A remoção de formaldeído na água residuária sintética foi maior que 90\% para doses abaixo de 400 mg/L e somente de 14\% para 3000 mg/L. Para a real, excedeu 98\% para concentrações abaixo de $200 \mathrm{mg} / \mathrm{L}$ e caiu para 28\% para a dose acima de $400 \mathrm{mg} / \mathrm{L}$. 
Os autores concluíram que o formaldeído é tóxico para a degradação anaeróbia, sendo a toxicidade dependente da concentração de formaldeído, dos componentes da água residuária e do tempo do teste. A concentração que causou 50\% da inibição foi de cerca de 150 mg/L para a água residuária real e 300 mg/L para a sintética. Devido aos tempos de inibição demonstrados na produção de gás, os autores afirmam que o tempo de adaptação depende da velocidade de crescimento das bactérias. Também observaram que a remoção de formaldeído foi menos inibida que a de DQO ou que a produção de gás, indicando a possibilidade dos microorganismos anaeróbios estarem inibidos, mas os resistentes ao formaldeído, não.

Os autores sugerem que a concentração de formaldeído no reator para tratamento da água residuária real seja menor que 100 mg/L, necessitando de uma grande diluição prévia.

OMIL et al. (1999) estudaram a biodegradação de formaldeído sob condições anaeróbias em digestores em batelada, na presença e ausência de co-substratos compostos por ácidos voláteis. A biomassa empregada foi coletada de uma estação de tratamento de uma indústria de processamento de frutos do mar, não adaptada previamente. A temperatura não foi indicada no trabalho. Foram utilizados dois tipos de substratos com misturas de ácidos voláteis (acético, propiônico e butírico), além de minerais, elementos traço e $\mathrm{NaHCO}_{3}$ para manter o pH na faixa de 7,0. Em ensaios abióticos, a remoção por volatilização ou transformação química foi de $10 \%$ a $11 \%$. Nos ensaios de biodegradabilidade, as concentrações de formaldeído foram de $0 \mathrm{mg} / \mathrm{L}$ a $300 \mathrm{mg} / \mathrm{L}$, sendo que somente para 50 mg/L houve degradação completa do formaldeído, geração e consumo total de metanol e completa conversão a metano. Nas concentrações maiores, houve degradação do formaldeído, porém acúmulo do metanol e conversão parcial a metano. Na concentração de 300 mg/L não houve produção de metano e a degradação de formaldeído foi de apenas 24\%, embora o formaldeído tenha sido quantitativamente convertido a metanol em $18 \%$.

Nos ensaios de toxicidade, as concentrações foram de $0 \mathrm{mg} / \mathrm{L}$ a $200 \mathrm{mg} / \mathrm{L}$ de formaldeído, com substratos contendo alta proporção de acetato (sistema M1) e altas proporções de propionato e de butirato (sistema M2). Nos ensaios com M1, para a concentração de $50 \mathrm{mg} / \mathrm{L}$, o acetato foi o primeiro substrato a ser degradado, seguido do butirato, enquanto o propionato permaneceu no meio sem alteração. Cerca de $90 \%$ do formaldeído foi removido já no primeiro dia. O metanol foi detectado e permaneceu no meio, sendo degradado somente no final do experimento. Nas concentrações maiores, a degradação do formaldeído foi obtida, embora com fases de atraso; a degradação dos ácidos também foi parcial e com fases de atraso; o metanol foi continuamente gerado, sendo degradado no final dos experimentos, após fases de atraso. Nos ensaios com o sistema M2, 
os resultados foram semelhantes aos do M1, embora as degradações de butirato e propionato tenham apresentado fases lag bem menores que em M1. As concentrações de metanol observadas com M2 foram sempre mais baixas que com M1, sendo também degradado no final, exceto na concentração de 200 mg/L de formaldeído.

Nos testes de atividade metanogênica, os resultados demonstraram que houve maior atividade do lodo para M1 que para M2. Na ausência de co-substrato, foi observada remoção de formaldeído significativamente menor. Comparando-se os co-substratos M1 e M2, a maior degradação em todos os casos foi obtida com M1, onde a concentração de 125 mg/L causou 50\% de inibição na atividade específica $\left(\mathrm{IC}_{50 \%}\right)$ e com M2, essa concentração foi de 100 mg/L. Em ensaios com ausência ou presença de sulfato não houve evidências de que as bactérias redutoras de sulfato possam crescer com formaldeído e na ausência de sulfato. Os autores concluíram que o formaldeído foi principalmente removido pelos processos biológicos envolvendo a formação de metanol e hidrogênio, finalmente convertidos a metano, dependendo da concentração inicial de formaldeído (Tabela 3.1). Embora o metanol tenha sido observado como um intermediário fundamental em todos os ensaios, suas maiores concentrações foram atingidas quando não foram usados co-substratos, sugerindo que a sua remoção somente aconteceu quando as arqueas metanogênicas não foram afetadas pelo formaldeído.

Tabela 3.1 - Reações envolvendo a degradação anaeróbia de formaldeído de acordo com os relatos de OMIL et al. (1999)

\begin{tabular}{cc}
\hline Reação & $\Delta G^{o}$ \\
\hline $\mathrm{HCOH}+\mathrm{H}_{2} \mathrm{O} \rightarrow 2 \mathrm{H}_{2}+\mathrm{CO}_{2}$ & $-21,8$ \\
$\mathrm{HCOH}+\mathrm{H}_{2} \rightarrow \mathrm{CH}_{3} \mathrm{OH}$ & $-44,0$ \\
\hline
\end{tabular}

VIDAL et al. (1999) realizaram estudos para a análise da toxicidade do formaldeído em ensaios em batelada, usando ácidos voláteis como co-substrato. Foi utilizada biomassa não aclimatada de um reator anaeróbio para tratamento de água residuária de indústria de processamento de frutos do mar. Os ensaios foram feitos em frascos fechados de vidro escuro com volumes total e útil de $126 \mathrm{~mL}$ e $100 \mathrm{~mL}$, respectivamente. Cada frasco foi inoculado com 1,5 g de SSV/L. O meio foi composto por uma mistura de ácidos voláteis (acético, propiônico e n-butírico) e concentrações de 25, 50, 100, 150 e 200 mg/L de formaldeído. $\mathrm{O} \mathrm{pH}$ foi ajustado para 7 e a temperatura foi de $35^{\circ} \mathrm{C}$. Foram feitas 3 alimentações sucessivas em cada experimento, sendo duas com a mesma concentração de formaldeído e a terceira sem formaldeído (somente a solução de ácidos voláteis). Os autores 
verificaram que, em concentrações de formaldeído superiores a $50 \mathrm{mg} / \mathrm{L}$, houve redução da produção de metano. Esse efeito aumentou na faixa de 50 a $150 \mathrm{mg} / \mathrm{L}$ de formaldeído, embora fosse completa a degradação dos ácidos voláteis. Com 200 mg/L, não houve produção de metano nos 13 dias do experimento. Após a terceira alimentação, sem formaldeído, os lodos dos experimentos contendo inicialmente $50 \mathrm{mg} / \mathrm{L}$ e $100 \mathrm{mg} / \mathrm{L}$ mostraram completa recuperação da atividade metanogênica, muito próximas à do controle. Para os ensaios com 150 mg/L foi observada certa inibição, sendo muito mais acentuada para $200 \mathrm{mg} / \mathrm{L}$, quando ocorreu uma fase lag de 12 dias. Os autores observaram que o tempo necessário para a recuperação da biomassa parece estar diretamente relacionado à dose de exposição ao formaldeído. A concentração de formaldeído que causou um decréscimo de 50\% na atividade metanogênica $\left(\mathrm{IC}_{50}\right)$ foi de aproximadamente $100 \mathrm{mg} / \mathrm{L}$. Este valor foi claramente mais baixo que os obtidos por outros pesquisadores, embora tivessem utilizado co-substratos diferentes. Os autores sugerem que esse fato pode indicar que exista uma relação entre o efeito do formaldeído na atividade microbiana e a natureza do co-substrato.

GONZALEZ-GIL et al. (1999) investigaram o destino do formaldeído em biorreatores anaeróbios, sob três aspectos: se o formaldeído ou seus produtos intermediários são o substrato para a metanogênese; se a toxicidade do formaldeído foi reversível ou irreversível, se a toxicidade do formaldeído depende da carga ou de sua concentração. Como inóculo, foi utilizado lodo granular anaeróbio de um reator em escala real tipo EGSB, tratando água residuária de indústria química, contendo formaldeído e metanol. Foram feitos ensaios para avaliar a conversão do formaldeído, em frascos de soro de $250 \mathrm{~mL}$, com concentração de biomassa de 0,8 g SSV/L e formaldeído como única fonte de carbono, além do metanol presente em $10 \%$ na solução de formol. As concentrações de formaldeído foram de $200 \mathrm{mg} / \mathrm{L}, 600 \mathrm{mg} / \mathrm{L}$ e $1400 \mathrm{mg}$ DQO/L. Para as concentrações de 200 mg/L e $600 \mathrm{mg}$ DQO/L, toda a DQO de substrato pôde ser convertida a DQO de metano. No entanto, 1400 mg DQO/L, tornou o formaldeído altamente tóxico e não foi observada nenhuma produção de metano, embora a conversão do formaldeído em metanol não fosse inibida. O maior pico de hidrogênio medido no "headspace" foi diretamente relacionado com a maior quantidade de formaldeído no afluente. Os autores sugeriram que provavelmente o formaldeído foi oxidado para ácido fórmico (3.2) e então reduzido para metanol (3.3), resultando nas reações a seguir, considerando que todo o formaldeído foi convertido a metanol e ácido fórmico (3.4):

$$
\begin{array}{cc}
\text { Oxidação } & \mathrm{HCHO}+\mathrm{H}_{2} \mathrm{O} \rightarrow \mathrm{HCOOH}+\mathrm{H}_{2} \\
\text { Redução } & \mathrm{HCHO}+\mathrm{H}_{2} \rightarrow \mathrm{CH}_{3} \mathrm{OH} \\
\text { Total } & 2 \mathrm{HCHO}+\mathrm{H}_{2} \mathrm{O} \rightarrow \mathrm{CH}_{3} \mathrm{OH}+\mathrm{HCOOH}
\end{array}
$$


Experimentalmente, os autores só verificaram a formação de 55-75\% do metanol esperado, provavelmente porque parte do formaldeído reagiu quimicamente com componentes celulares ou foi adsorvido pela biomassa. Os autores também citam a possibilidade de ter havido redução do formaldeído a $\mathrm{CH}_{4}$ por Methanobacterium thermoautotrophicum, conforme citado por ESCALANTE-SEMERENA \& WOLFE (1984). Na concentração de 1400 mg DQO/L, a velocidade de reação para conversão do formaldeído decresceu com o tempo, podendo sugerir que enzimas ou cofatores possam ter sido desnaturados.

Nesse mesmo trabalho, GONZALEZ-GIL et al. (1999) também investigaram a toxicidade do formaldeído em baixa e alta (ver item 3.2.2) concentrações de biomassa. Para os estudos em baixa concentração de biomassa foram utilizados reatores em batelada de 2,5 L, com agitação contínua, inoculados com o mesmo lodo do ensaio anterior a 1,4 g SSV/L. Metanol foi adicionado como fonte de carbono com concentração inicial de 10 g DQO/L, além de meio mineral. O formaldeído foi adicionado lentamente, após cerca de 2 g DQO de metanol terem sido consumidas. Com uma dose de $10 \mathrm{mg} / \mathrm{L}$ de formaldeído, não houve mudança na velocidade de produção de metano. Porém, com $50 \mathrm{mg} / \mathrm{L}$ ou mais, houve uma queda imediata e aguda na velocidade de produção de metano, embora com doses de 600 $\mathrm{mg} / \mathrm{L}$, a produção de metano não cessasse completamente. Ainda que o formaldeído fosse completamente convertido, o crescimento da biomassa só foi observado após 100 h do início do experimento. Os autores verificaram, logo após a adição de formaldeído, o aumento da concentração de hidrogênio no "headspace” do frasco. Entretanto, a máxima concentração de $\mathrm{H}_{2}$ não correspondeu à máxima conversão de formaldeído, sugerindo uma limitação na transferência de massa do líquido para o gás. Os autores também reportaram que a recuperação da biomassa após as 100 h pode, provavelmente, ser atribuída principalmente ao crescimento das bactérias.

GONZALEZ-GIL (2000) estudou a conversão e toxicidade de formaldeído num consórcio metanogênico acetoclástico. Da mesma forma que no trabalho anterior (GONZALEZ-GIL et al., 1999), foi avaliado se a toxicidade a formaldeído foi reversível ou não e se dependeu da carga e concentração deste tóxico. Para o inóculo, foi utilizado lodo granular anaeróbio de um reator tipo EGSB tratando água residuária de cervejaria, com 3,5 g SSV/L. A conversão do formaldeído como única fonte de carbono foi estudada em frascos de soro de $300 \mathrm{~mL}$, com volume líquido de $150 \mathrm{~mL}$, contendo minerais e elementos traço. Os frascos foram fechados e transferidos para incubador rotativo ("shaker") a $30^{\circ} \mathrm{C}$. A conversão de formaldeído foi estudada nas concentrações $90 \mathrm{mg} / \mathrm{L}$ a $1000 \mathrm{mg} / \mathrm{L}$, sem nenhuma fase lag observável, com a formação concomitante de metanol e formiato. A 
metanogênese a partir do metanol ocorreu depois de $50 \mathrm{~h}$, sugerindo que os microorganismos consumidores de metanol estavam presentes em pequeno número. A autora verificou claramente a transformação de formaldeído (utilizado como única fonte de carbono) em ácido fórmico e metanol. Com base nas relações $\mathrm{CH}_{3} \mathrm{OH} / \mathrm{HCHO}$ de 0,7/2 a 0,9/2, medidas nesse estudo, a autora sugere novamente as reações 3.2, 3.3 e 3.4 já citadas anteriormente (GONZALEZ-GIL et al., 1999); no entanto, não indica os microorganismos envolvidos nessa conversão.

Nos estudos de toxicidade, foram utilizados reatores em batelada de 2,5 L, continuamente agitados, inoculados com suspensão de lodo de concentração final entre 1,5 e 3,0 g SSV/L. O meio utilizado continha minerais e elementos traço, com tampão de fosfato mantendo pH entre 6,8 e 7,2. Inicialmente foram alimentados com acetato até a estabilização da produção de metano; então formaldeído foi adicionado, tanto de forma intermitente, como em modo contínuo (ver item 3.2.2). Na adição intermitente, foram utilizadas concentrações entre $100 \mathrm{mg} / \mathrm{L}$ e $1000 \mathrm{mg} / \mathrm{L}$ de formaldeído, sendo que em todas as concentrações testadas houve grande inibição na velocidade de produção de metano. Os resultados mostraram que os declínios das fases de inibição foram independentes das concentrações de formaldeído adicionadas. Entretanto, as acelerações das fases de recuperação diminuiram à medida que a concentração aumentou. A recuperação foi parcial em todas as concentrações de formaldeído acima de $45 \mathrm{mg} / \mathrm{L}$. A autora também observou que a queda na produção de metano parece estar linearmente relacionada com a quantidade de formaldeído adicionado. No modo contínuo de adição, os resultados foram muito próximos aos da alimentação intermitente, causando toxicidade irreversível similar. A autora sugere que uma certa quantidade de formaldeído inibe irreversivelmente uma certa quantidade de biomassa, reduzindo, assim, a velocidade de produção de metano numa certa extensão, independente do modo de adição do formaldeído. Também sugere que para se evitar a falha de um processo anaeróbio, o decaimento da biomassa, intensificado pelo formaldeído, deve ser compensado pelo crescimento líquido da biomassa. A razão formaldeído/acetato, ou outro co-substrato não tóxico, é um fator importante na determinação do crescimento líquido da população microbiana. Acrescenta, também, que deve haver uma boa retenção de biomassa.

\subsubsection{Ensaios em Sistemas Contínuos}

PARKIN \& SPEECE (1983) avaliaram a toxicidade de seis substâncias presentes em águas residuárias industriais: cianeto, clorofórmio, formaldeído, amônia, níquel e sulfeto. 
Para investigar o desempenho de sistemas de tratamento com biomassas suspensa e aderida, foram utilizados reatores tipo tanques, continuamente agitados, e filtro anaeróbio, respectivamente. Foram utilizadas culturas acetoclásticas e a temperatura dos experimentos foi de $35^{\circ} \mathrm{C}$. Nos ensaios, acetato foi utilizado como co-substrato, além de solução de nutrientes. As concentrações de formaldeído nos estudos foram de $300 \mathrm{mg} / \mathrm{L}, 600 \mathrm{mg} / \mathrm{L}$ e $1800 \mathrm{mg} / \mathrm{L}$, com tempos de exposição de uma hora, um dia e quatro dias. Os autores observaram nos ensaios de toxicidade momentânea (“transient”) que, para uma determinada dose empregada, os filtros anaeróbios exibiram pouco ou nenhum tempo de atraso na produção de metano, enquanto que os reatores de mistura ficaram períodos de 20 a 50 dias sem produzir metano. Para produzir a mesma queda de eficiência em sistema de leito fixo, foram necessárias doses de tóxico entre 10 e 100 vezes maiores que a aplicada em reator de mistura. Nos ensaios de toxicidade crônica, com adição contínua de formaldeído, a concentração máxima que não causou queda na eficiência do processo foi similar nos dois tipos de reatores (400 mg/L). No entanto, o filtro anaeróbio não perdeu biomassa durante o período de aclimatação. Os autores concluíram que longos períodos sem produção de gás não significam o colapso do sistema. Reportam também, que os reatores com crescimento aderido podem fornecer o tempo de retenção celular (TRC) necessário sem os inconvenientes do grande tamanho do reator ou do reciclo da biomassa. Portanto, ressaltam que reatores de crescimento aderido ou outros que forneçam um alto TRC e baixo tempo de detenção hidráulica (TDH) são os mais adequados para o tratamento de águas residuárias contendo tóxicos com adição momentânea ou contínua.

PARKIN et al. (1983) estudaram a toxicidade de quatro substâncias presentes em águas residuárias industriais, sendo uma delas o formaldeído. Para os ensaios em sistemas contínuos, utilizaram filtros anaeróbios de acrílico transparente, com $5 \mathrm{~cm}$ de diâmetro interno e $1 \mathrm{~m}$ de altura, com 2,5 cm de seu diâmetro nominal preenchido com pedregulho. $\mathrm{O}$ volume não ocupado foi de $1 \mathrm{~L}$. O inóculo foi retirado do digestor de estoque, a partir de lodo de estação municipal, tratado com acetato e nutrientes por quatro anos. A alimentação foi feita com substrato à base de acetato e nutrientes, para um tempo de detenção hidráulica (TDH) nominal de 1 dia. A adição contínua de formaldeído não causou inibição para concentrações de até $400 \mathrm{mg} / \mathrm{L}$. Os autores concluíram que os reatores com valores muito altos de tempo de retenção celular (TRC) e relativamente baixos de TDH como filtro anaeróbio, leito fluidizado anaeróbio e UASB, apresentam maior potencialidade para o tratamento eficaz de águas residuárias industriais contendo tóxicos.

BORGHANS \& VAN DRIEL (1988) estudaram a possibilidade de tratamento de água residuária contendo fenol e formaldeído, além de outras substâncias tóxicas, em reator 
tipo UASB. A DQO dessa água residuária foi de 30,5 g/L, com concentração de formaldeído de $900 \mathrm{mg} / \mathrm{L}$. Inicialmente foram feitos ensaios de laboratório, em batelada, dos quais foram obtidas eficiências de remoção de DQO de 95\%, com taxa de carregamento orgânico de 9-12 $\mathrm{kg}$ de $\mathrm{DQO} / \mathrm{m}^{3}$ de reator e remoção de formaldeído de 99\%. Para os estudos em escala piloto foi instalado um reator Biothane ${ }^{\circledR}$ (UASB) com volume de $6 \mathrm{~m}^{3}$, ligado a um tanque de mistura rápida para correção do $\mathrm{pH}$, temperatura e mistura de nutrientes e água de diluição proveniente de um rio. Nesse reator também foram estudadas as características e o crescimento do lodo, além da influência da variação local da composição da água residuária. Esse reator piloto confirmou os resultados encontrados em laboratório, apresentando grande estabilidade apesar das variações da água residuária. Construiu-se, então, um reator Biothane ${ }^{\circledR}$ em escala real, que após 2 anos de partida, apresentou resultados conforme as expectativas, tendo eficiências de mais de 95\% na remoção de DQO, com 9 meses de operação. Os autores concluem, resumidamente, que as águas residuárias de processos químicos também podem ser tratadas por digestão anaeróbia em reatores Biothane ${ }^{\circledR}$, porém devem ser feitas pesquisas antes de se decidir pela aplicação em escala real. Os autores citaram que a diluição é feita com água de rio, entretanto não informaram a porcentagem utilizada nos processos.

SHARMA et al. (1994) estudaram a biodegradação de água residuária de indústria petroquímica usando partículas de suporte para imobilização da biomassa. A água residuária era composta por acetato de metila, ácido fórmico, formaldeído, metanol e ácido acético. Foi utilizado um reator tipo tanque com agitação contínua, com volume de 2,5 L, com temperatura de $35^{\circ} \mathrm{C} \pm 2{ }^{\circ} \mathrm{C}$, inoculado com lodo de digestor anaeróbio ativo. Por 20 dias, o reator foi operado de modo semi-contínuo, com 3 g DQO/L por dia. Após a estabilização, foi operado de modo contínuo com TDH de 10 dias. As partículas de suporte foram de polietileno de baixa densidade, utilizadas em cilindros com $5 \mathrm{~cm}$ de comprimento, volume médio de $14 \mathrm{~mL}$, densidade de 0,91 g/mL e volume vazio de 82\%. Essas partículas foram adicionadas a 20 \% (v/v), após a estabilização, sendo mantido como controle, um reator sem as partículas. A adição das partículas resultou em redução de sólidos suspensos (SS) no efluente de cerca de $900 \mathrm{mg} / \mathrm{L}$ para $180 \mathrm{mg} / \mathrm{L}$, enquanto a redução de DQO e formação de biogás aumentou somente $5 \%$ a 10\%. O TRC no reator com partículas passou para mais de 200 dias, enquanto o TRC no controle era de 8 a 10 dias. Com uma concentração de formaldeído acima de $125 \mathrm{mg} / \mathrm{L}$, houve um declínio na redução de DQO e produção de biogás no reator de controle, enquanto que, no reator com partículas, isso só ocorreu em concentrações acima de $375 \mathrm{mg} / \mathrm{L}$ de formaldeído. Mantendo-se essas concentrações nos dois tipos de reatores, a remoção de formaldeído foi de 85 \% a 88\% no reator de controle e 
$95 \%$ a 98\% no reator com partículas. Os autores também observaram que houve recuperação mais rápida da toxicidade nos reatores com partículas.

Além dos ensaios em batelada já descritos anteriormente, QU \& BHATTACHARYA (1997) realizaram estudos em três quimiostatos, com cultura acetoclástica, investigando os efeitos da adição contínua de formaldeído nessa cultura, na aclimatação e na degradação, em reatores contínuos. A solução de alimentação foi constituída de acetato, formaldeído e nutrientes, mantendo-se o pH em 7,0 \pm 0,2 e TDH e TRC de 14 dias. O quimiostato I foi alimentado inicialmente com 7,5 g/L de acetato e nutrientes por 103 dias, quando a concentração de $100 \mathrm{mg} / \mathrm{L}$ de formaldeído começou a ser adicionada, atingindo até $1110 \mathrm{mg} / \mathrm{L}$, no $226^{\circ}$. dia de experimento. O quimiostato II foi alimentado com 7,5 g/L de acetato por 37 dias, e então foi adicionada a concentração de 370 $\mathrm{mg} / \mathrm{L}$ de formaldeído por 22 dias. No $60^{\circ}$. dia, a concentração foi aumentada para $740 \mathrm{mg} / \mathrm{L}$, permanecendo por 71 dias. O quimiostato III foi utilizado para os estudos de carga de choque de formaldeído, sendo adicionadas as concentrações de formaldeído de $30 \mathrm{mg} / \mathrm{L}$ e 60 mg/L de formaldeído após 93 dias de operação. Os resultados de degradação encontrados para concentrações em torno de $400 \mathrm{mg} / \mathrm{L}$ nos quimiostatos I e II foram muito próximos, embora o II não tenha apresentado um período de aclimatação. Para a concentração de 740 $\mathrm{mg} / \mathrm{L}$, no quimiostato II não foi detectado acetato no efluente acima de $50 \mathrm{mg} / \mathrm{L}$, enquanto no I, as concentrações de acetato efluente foram em torno de $200 \mathrm{mg} / \mathrm{L}$ entre o $230^{\circ}$. dia e o $280^{\circ}$. dia. A degradação de formaldeído foi quase completa em ambos. Após 300 dias de operação, a concentração afluente de formaldeído no quimiostato I foi de $1110 \mathrm{mg} / \mathrm{L}$, com um efluente de menos de $1 \mathrm{mg} / \mathrm{L}$ (velocidade de remoção de $164 \mathrm{mg}$ formaldeído/g SSV.dia). Foram observados aumentos significativos na concentração de biomassa nos quimiostatos que, somados à produção de metano, são fortes indicadores da biodegradação do formaldeído. No quimiostato III, $30 \mathrm{mg} / \mathrm{L}$ de formaldeído causaram uma inibição imediata, elevando a concentração de acetato efluente para $284 \mathrm{mg} / \mathrm{L}$. Após 24 h houve a completa degradação do formaldeído, cessando a inibição. Quando foram adicionados 60 mg/L de formaldeído, foi observado um período maior de inibição (6,5 dias), com aumento da concentração efluente de acetato para $2550 \mathrm{mg} / \mathrm{L}$. O formaldeído foi completamente degradado em 4 dias e a concentração de acetato baixou para 70 mg/L somente após 20 dias. Os autores concluíram que a razão $\mathrm{S}_{0} / \mathrm{X}_{0}$ (formaldeído/biomassa) e a concentração de formaldeído podem ser usados como parâmetros para prever o desempenho de um sistema anaeróbio após uma carga de choque.

ZOUTBERG \& DE BEEN (1997) apresentam os resultados de degradação anaeróbia de água residuária de indústria química, em um reator em escala real, denominado 
Biobed $^{\circledR}$ EGSB (leito de lodo granular expandido). A água residuária era composta por aproximadamente $20 \mathrm{~g} / \mathrm{L}$ de metanol e $10 \mathrm{~g} / \mathrm{L}$ de formaldeído e o sistema de tratamento, composto por dois tanques e um reator. O primeiro tanque foi utilizado para equalização, recebendo a água residuária bruta, com capacidade de $150 \mathrm{~m}^{3}$ e TDH de aproximadamente 30 horas. O segundo tanque, para condicionamento, com volume de $20 \mathrm{~m}^{3}$, recebia $5 \mathrm{~m}^{3} / \mathrm{h}$ de água residuária bruta do tanque anterior e $145 \mathrm{~m}^{3} / \mathrm{h}$ do efluente tratado do reator EGSB subseqüente, fornecendo uma vazão final de $150 \mathrm{~m}^{3} / \mathrm{h}$ para o reator. No tanque de condicionamento também eram adicionados micro e macro nutrientes, além de haver o controle do pH em torno de 7,0. O reator EGSB, com volume de $275 \mathrm{~m}^{3}$ e leito de lodo de 14 $\mathrm{m}$ de altura, recebia, como afluente, o líquido condicionado, com uma concentração 30 vezes menor que a da água residuária bruta, perfazendo uma concentração de formaldeído aproximada de $333 \mathrm{mg} / \mathrm{L}$. O reator foi inoculado inicialmente com lodo granular proveniente de reator UASB Biothane ${ }^{\circledR}$. De acordo com os autores, as características importantes desse reator são a possibilidade de se alcançar uma velocidade ascensional de até $15 \mathrm{~m} / \mathrm{h}$, sem que haja lavagem do reator, enquanto em reator UASB, essa velocidade é de cerca de $1 \mathrm{~m} / \mathrm{h}$. Os autores alcançaram uma eficiência de remoção de DQO acima de 98\% com esse sistema, onde a DQO afluente é de cerca de $40 \mathrm{~g} / \mathrm{L}$ e a efluente é de, aproximadamente, $800 \mathrm{mg} / \mathrm{L}$. Após esse tratamento, há um sistema tipo Carrousel ${ }^{\circledR}$ para minimizar a DQO desse efluente.

Os ensaios de GONZALEZ-GIL et al. (1999) em batelada já foram descritos anteriormente. Para o estudo da toxicidade em reator contínuo, com alta concentração de biomassa, foi utilizado um reator tipo EGSB de $4 \mathrm{~L}$, inoculado com lodo granular com concentração final de 23 g SSV/L. O reator foi operado continuamente com uma velocidade ascensional de $6 \mathrm{~m} / \mathrm{h}$. Foi adicionado metanol como fonte de carbono, com concentração inicial de 5 g DQO/L. Também foram adicionados minerais e elementos traço. A adição de formaldeído foi feita de formas intermitente e contínua. No primeiro caso, o reator EGSB foi operado em modo de batelada. Só foi adicionado o formaldeído quando foi alcançada uma produção máxima e constante de metano. Após a adição de formaldeído, a velocidade de produção de metano foi imediatamente inibida, mas a conversão procedeu sem nenhuma fase lag, como nos ensaios anteriores. Para todas as concentrações testadas (200 mg/L, $400 \mathrm{mg} / \mathrm{L}$ e $600 \mathrm{mg} / \mathrm{L}$ ), o formaldeído foi removido em duas horas, mas houve forte inibição. A recuperação está diretamente relacionada com a dose de formaldeído adicionado.

Para os autores, esses resultados provaram que a toxicidade do formaldeído é em parte reversível, uma vez que houve recuperação da velocidade de produção de metano após a conversão do formaldeído. Os autores também sugerem que a toxicidade irreversível 
parece ter uma relação linear com respeito ao formaldeído dosado e provavelmente pode ser atribuída ao decaimento da concentração da biomassa. Os ensaios com adição contínua foram feitos para avaliar se a toxicidade irreversível do formaldeído dependia da sua concentração no volume líquido ("bulk”) ou na quantidade total de formaldeído dosado. Após obter-se a velocidade máxima e constante de produção de metano, adicionou-se formaldeído de modo contínuo, por uma hora, nas concentrações de 200 mg/L e 400 mg/L. Foi observado que, embora a concentração de formaldeído na fase líquida fosse baixa (ao redor de $7 \mathrm{mg} / \mathrm{L}$ e $50 \mathrm{mg} / \mathrm{L}$ para $200 \mathrm{mg} / \mathrm{L}$ e $400 \mathrm{mg} / \mathrm{L}$, respectivamente), a velocidade de produção de metano foi decrescendo gradualmente, sendo o decréscimo final, próximo ao do modo de adição intermitente. Os autores observaram que, com a adição da mesma quantidade de formaldeído, tanto de forma intermitente quanto contínua, houve a mesma queda na velocidade de produção de metano. Essa queda durante o modo contínuo sugere uma toxicidade irreversível, provavelmente devido ao decaimento da biomassa.

$\mathrm{Na}$ análise microscópica do lodo, os autores observaram que a camada externa dos grânulos era composta principalmente por Methanosarcinas, muitas delas em lise, sugerindo uma acentuada diminuição da concentração celular devido ao formaldeído. Sendo assim, os autores sugerem que para o tratamento de efluentes industriais contendo formaldeído deve-se combinar uma boa retenção da biomassa e uma diluição da água residuária.

Nos ensaios em reatores de tratamento contínuo, VIDAL et al. (1999) utilizaram dois reatores de vidro (R1 e R2), tipo UASB, com comprimento de 200 mm, diâmetro interno de $30 \mathrm{~mm}$ e volume efetivo de 0,1 L. Foram inoculados com 5,25 g SSV/L de lodo de tratamento de água residuária de industrialização de frutos do mar, não aclimatado, e colocados em câmara termostática a $37^{\circ} \mathrm{C}$. A alimentação inicial foi feita com glicose, solução tampão para manter o pH em 7,0 e solução de nutrientes. O reator R1 foi alimentado com meio sintético contendo glicose e formaldeído e o R2, com meio sintético com as mesmas características da água residuária de adesivos à base de uréia e formaldeído, além de glicose. Em R1 foram adicionadas concentrações de formaldeído de $50 \mathrm{mg} / \mathrm{L}$ a 2 g/L. As maiores eficiências de remoção de DQO (cerca de 98\%) foram para a concentração de 1,0 g/L de formaldeído. O reator manteve-se estável por toda a operação, como indicado pela sua alcalinidade. Para concentrações acima de 2,0 g/L, houve significativo decréscimo na remoção de DQO para valores abaixo de $70 \%$, afetando a metanogênese e decaindo a alcalinidade. Com a adição de $\mathrm{NaHCO}_{3}$, a alcalinidade foi recuperada e o reator voltou a ter alta eficiência de remoção de DQO (93\%), com operação estável. Devido à rápida recuperação do sistema, os autores propuseram que os distúrbios estariam mais relacionados com o aumento da taxa de carregamento orgânico aplicada, que à inibição causada pelo 
formaldeído. Em R2, as concentrações de formaldeído aplicadas foram de 95 mg/L a 950 mg/L. A eficiência de remoção de DQO foi sempre muito alta (90 \% a 95\%), sendo observado um pequeno decréscimo no final do experimento. A uréia foi completamente hidrolisada, causando a geração de amônia em quantidades baixas, que não afetaram a atividade metanogênica. Os autores concluíram que a tecnologia do reator UASB é compatível com o tratamento do efluente estudado, quando a alcalinidade adequada for mantida, bem como um controle rigoroso do $\mathrm{pH}$.

\subsection{Reator Anaeróbio Horizontal de Leito Fixo}

O reator anaeróbio horizontal de leito fixo (RAHLF) ou HAIS (Horizontal-flow Anaerobic Immobilized Sludge) foi proposto por ZAIAT et al. (1994) em escala de bancada e consiste, originalmente, em um tubo de vidro de $1,0 \mathrm{~m}$ de comprimento e 5,0 $\mathrm{cm}$ de diâmetro, provido com um tubo perfurado de $0,9 \mathrm{~cm}$ de diâmetro instalado em sua parte superior, para coleta e separação do gás. Esse tubo, mantido nos trabalhos iniciais com o reator, foi suprimido em trabalhos posteriores, por permitir a formação de caminhos preferenciais.

O reator foi inicialmente avaliado para tratamento de água residuária de indústria de papel reciclado (FORESTI et al., 1995). Posteriormente, o reator foi avaliado para tratamento de águas residuárias sintéticas simples, à base de glicose (ZAIAT et al., 1997), e complexas, contendo proteínas, carboidratos e lipídeos (SARTI et al., 2001), além de estudos com esgoto sanitário natural (ZAIAT et al., 2000). Em todos esses trabalhos, o interior do reator foi preenchido com matrizes cúbicas de espuma de poliuretano como suporte para imobilização da biomassa. A mistura axial devida à formação e ascensão do gás através do fluxo horizontal do líquido, bem como a forma do reator, pretendem promover um regime próximo ao tubular ideal.

O primeiro ensaio de um HAIS foi realizado por FORESTI et al. (1995), para tratamento de água residuária de indústria de papel, com TDH de 9,2 horas e temperatura ambiente $\left(\sim 23^{\circ} \mathrm{C}\right)$. A taxa de carregamento orgânico foi de 5,0 $\mathrm{kg} \mathrm{DQO} / \mathrm{m}^{3}$.dia, considerando-se o volume líquido. A eficiência de remoção de DQO foi, em média, de 82\%.

Nos estudos de ZAIAT et al. (1997) foi utilizado um HAIS em escala de laboratório, preenchido com matrizes de espuma de poliuretano, contendo lodo anaeróbio imobilizado de um UASB tratando água residuária diluída de atividade de suinocultura. A alimentação foi feita com um substrato sintético contendo glicose, como única fonte de carbono (DQO de 
$2.090 \mathrm{mg} / \mathrm{l}$ ), em dois experimentos com porosidades dos leitos ( $(\varepsilon)$ de 0,40 e 0,24, com TDH de 8,0 e 4,8 horas, respectivamente. A temperatura foi mantida a $30^{\circ} \mathrm{C}$ e foram monitorados DQO, ácidos graxos voláteis (AVT), alcalinidade total (AT) e $\mathrm{pH}$ nos quatro pontos de coleta intermediários (L/D de 4, 8, 12 e 16), bem como efluente (L/D de 20). Os autores observaram uma curta duração do período da partida (6 dias) nos 2 experimentos, comprovando rápida aclimatação, crescimento e retenção da biomassa. Para $\varepsilon=0,40$, a remoção da DQO foi de 98\%, para uma concentração de AVT efluente de 15 mg/L, enquanto que para $\varepsilon=0,24$, a eficiência máxima de remoção da DQO foi de $80 \%$, com concentração efluente de AVT elevada para 350 mg/L.

Os autores relatam que o baixo grau de mistura longitudinal no reator indica a possibilidade de seu uso para alguns propósitos específicos, como, por exemplo, águas residuárias contendo compostos tóxicos. Para tal, poderia ser utilizada uma parte isolada do reator HAIS, preenchida com lodo enriquecido de microorganismos capazes de degradar tais compostos, sem afetar a biomassa global dentro do reator.

Estudos com degradação de tóxicos no reator horizontal foram iniciados por Damianovic (1997) que avaliou o desempenho no tratamento de água residuária contendo pentaclorofenol. Esse trabalho demonstrou o grande potencial do reator para tratamento de tóxicos e foi seguido por trabalhos que enfocaram o tratamento de fenol (Bolaños et al., 2000) e BTEX (benzeno, tolueno, etilbenzeno e xilenos), desenvolvido por Nardi et al. (2000).

\subsection{Considerações Finais}

A literatura demonstra que ainda há escassez de dados sobre a degradação de formaldeído, tanto aeróbia como anaerobiamente. Nos trabalhos com degradação anaeróbia, não estão bem definidos as rotas de degradação, nem os seus produtos intermediários. Não há consenso quanto à concentração limite de formaldeído aplicável nos diversos tipos de sistemas. Também não se sabe ao certo, quais os fatores que indicam a falência dos sistemas, já que, em muitos casos, há inibição da produção de metano sem que a eficiência de remoção de formaldeído tenha queda significativa.

Ainda não há dados cinéticos para a elaboração de projetos racionais de reatores ou sistemas adequados para tratamento de águas residuárias contendo formaldeído. Apesar de terem sido alcançadas eficiências razoáveis no consumo de DQO e de formaldeído nos estudos realizados, foram utilizadas concentrações de formaldeído muito baixas em relação 
às encontradas na maior parte dos efluentes industriais. Outro fator importante é que foram utilizados co-substratos na maioria dos trabalhos, dificultando a identificação dos microorganismos específicos da degradação de formaldeído e produzindo substâncias intermediárias e ácidos voláteis que não pertencem, necessariamente, à rota de degradação do formaldeído.

Nos trabalhos desenvolvidos com tóxicos no RAHLF (DAMIANOVIC, 1997; BOLAÑOS et al., 2000; NARDI et al., 2000) ficou patente a sua potencialidade para o tratamento dessas substâncias, atingindo-se eficiências muito boas na remoção de DQO e de tóxicos. Em testes de biodegradabilidade, OMIL et al. (1999) demonstraram que formaldeído pode ser degradado como única fonte de carbono. Sendo assim, o RAHLF foi utilizado neste trabalho, sem co-substratos, pretendendo avaliar-se o comportamento específico da degradação de formaldeído.

A preocupação com a emissão de tóxicos no meio ambiente vem aumentando com a conscientização de seus riscos para a biota. A globalização dos estudos ambientais tem sido determinante para o desenvolvimento dessa conscientização e para a criação de leis e códigos rígidos na área ambiental. Em junho de 1992, no Rio de Janeiro, foi lançada a “Agenda 21" durante a Conferência das Nações Unidas sobre Meio Ambiente e Desenvolvimento - ECO 92. O gerenciamento de resíduos foi ponto de especial atenção, tanto na geração, reutilização, reciclagem e destino (Capítulo 21). As leis brasileiras referentes ao meio ambiente (Constituição Federal, Política Nacional do Meio Ambiente, Resoluções do CONAMA) e aos recursos hídricos (Política Nacional de Recursos Hídricos), são um forte instrumento para as autoridades agirem a favor da natureza. O apoio da população envolvida é também de suma importância nesta área.

Muitos problemas ambientais são encontrados em atividades não necessariamente industriais, como é o caso da Universidade de São Paulo. O Campus da USP de Ribeirão Preto, com sua grande produção científica e atividades relacionadas à saúde, acaba sendo também um grande gerador de resíduos.

CAMPOS \& DANIEL (1993) elaboraram um projeto de estação de tratamento de esgoto para o Campus de Ribeirão Preto, que ainda não pôde ser construída. Porém, o município está em vias de implantar a sua estação, cuja cobrança de taxas acarretará num valor razoável a ser cobrado do Campus da USP.

Com esse quadro, pode-se ver que é de suma importância agilizar a instalação de um sistema de tratamento de esgotos para o Campus, compatível com a sua realidade física e financeira e com os requisitos legais relativos ao meio ambiente. 
Como subsídio aos levantamentos de dados para esta futura estação, o presente trabalho procurou determinar a influência que os efluentes de laboratórios de anatomia contendo formaldeído poderão ter num processo anaeróbio de tratamento. Optou-se por este efluente tendo em vista o escasso desenvolvimento de pesquisas sobre o assunto, ao contrário da maior parte dos demais efluentes do Campus, como o próprio esgoto sanitário ou outros contaminados por produtos tóxicos e patológicos. 


\section{MATERIAL E MÉTODOS}

\subsection{Reator}

Para o estudo foi utilizado um reator anaeróbio horizontal de leito fixo, confeccionado em vidro boro silicato, em escala de bancada. O comprimento (L) do reator é $100 \mathrm{~cm}$, com diâmetro interno (D) de 5,0 cm, perfazendo uma relação comprimento por diâmetro (L/D) de aproximadamente 20. O volume total aproximado é de 2 litros. Para a coleta de amostras há 4 quatro pontos em L/D de 4, 8, 12 e 16. A coleta de biogás é feita na mangueira superior que liga o coletor de gases ao selo hídrico (Figura 4.1).

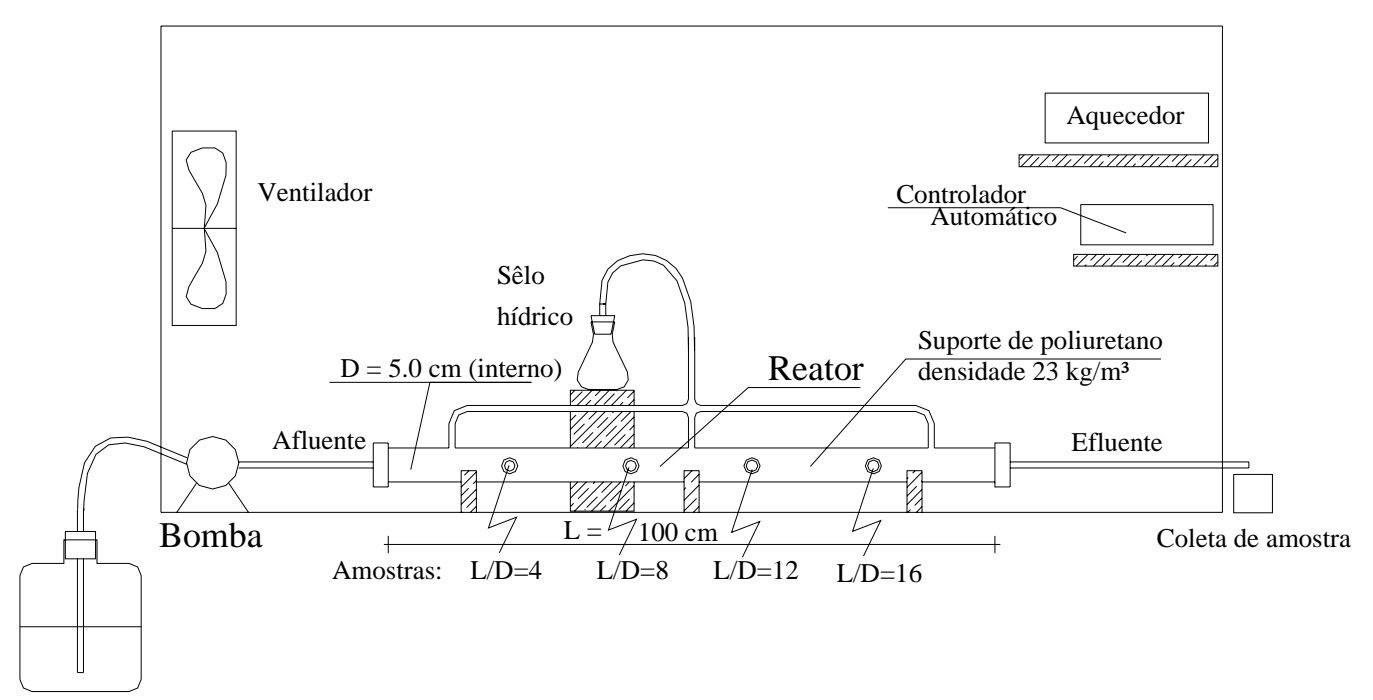

Figura 4.1: Esquema de reator anaeróbio horizontal de leito fixo.

O reator foi mantido em câmara de madeira, contendo sistema de controle de temperatura composto de um aquecedor, um ventilador e um controlador automático de temperatura.

Para a alimentação do reator foi utilizada bomba peristáltica Ismatec, modelo IPC-N4-V2-03. Para evitar interrupção no experimento, a bomba foi ligada a um "no-break".

Como suporte de imobilização da biomassa, foi utilizada espuma de poliuretano em cubos de $5 \mathrm{~mm}$ de aresta, com densidade de $23 \mathrm{~kg} / \mathrm{m}^{3}$. 


\subsection{Substrato}

Para o estudo foi utilizado um substrato sintético com concentrações crescentes de formaldeído e meio Angelidaki (ANGELIDAKI et al., 1990), descrito na Tabela 4.1, para o suprimento de sais, metais e vitaminas.

As concentrações médias de formaldeído estudadas foram de 26,2, 85,3 , 175,9 , 394,0 , 597,7 , 808,0 , 989,2 , 1158,6 e 1416,8 mg/L. Tais concentrações têm base na bibliografia para possibilitar comparações entre os resultados.

O formaldeído foi obtido a partir de solução de formol, contendo $38 \%$ de formaldeído e $10 \%$ de metanol (estabilizador), em média, e apresentando densidade de $1,081 \mathrm{~g} / \mathrm{mL}$.

A complementação do substrato foi feita com Meio Angelidaki, em água de torneira. Foram preparadas soluções de estoque para o meio basal e solução de vitaminas. A solução de extrato de levedura foi preparada quinzenalmente, evitando a proliferação de microorganismos. A solução tampão, composta de bicarbonato de sódio e água destilada, foi preparada a cada troca de substrato. Todas as soluções do meio foram preparadas com substâncias P.A., sendo estocadas sob refrigeração, exceto a fonte de potássio (K2HPO4) para não ocorrer cristalização. 
Tabela 4.1: Composição do Meio Angelidaki (ANGELIDAKI et al., 1990).

\begin{tabular}{lc}
\hline Componente & Concentração (mg/L) \\
\hline 1. Meio basal (A + B + C) & \\
Solução macro (A) & 100 \\
NaCl & 100 \\
MgCl2.6H2O & 50 \\
CaCl2.2H20 & \\
Fonte de Nitrogênio e Potássio (B) & 100 \\
NH4CL & 400 \\
K2HPO4.3H20 & \\
Solução de metais e Selenito (C) & 2 \\
FeCl2.4H2O & 0,05 \\
H3BO3 & 0,05 \\
ZnCl2 & 0,038 \\
CuCl2.2H2O & 0,05 \\
MnCl2.4H2O & 0,05 \\
(NH4)6Mo7)O24.4H2O & 0,05 \\
AlCl3 & 0,05 \\
CoCl2.6H2O & 0,092 \\
NiCl2.6H2O & 0,5 \\
EDTA & $0,001 \mathrm{ml} / 1$ \\
HCl concentrado & 0,1 \\
Na2SeO3.5H2O & \\
2. Solução de vitaminas (E) & 0,009 \\
D-biotina & 0,009 \\
Acido Fólico & 0,0225 \\
Riboflavina & 0,0225 \\
Hidrocloreto deTiamina & 0,0225 \\
Cianocobolamina & 0,0225 \\
Nicotinamida & 0,0225 \\
Ac. p-aminobenzoico & 0,045 \\
Hidrocloreto de pirodonina & 0,5 \\
3. Extrato de levedura & Variável \\
4. Fonte de carbono -formaldeído & 2000 \\
5. Solução tampão & \\
& \\
&
\end{tabular}

\subsection{Métodos Analíticos}

Durante os experimento foram monitorados os seguintes parâmetros:

o Demanda Química de Oxigênio - DQO

o Sólidos Totais (ST)

o Sólidos Voláteis Totais (SVT)

o Sólidos Suspensos Totais (SST)

o Sólidos Suspensos Voláteis (SSV)

o Alcalinidade 

o $\mathrm{pH}$
o Concentração de Formaldeído
o Composição do Biogás
o Vazão do efluente
o Temperatura

As análises de DQO, sólidos totais (ST), sólidos voláteis totais (SVT), sólidos suspensos totais (SST) e sólidos suspensos voláteis (SSV) foram realizadas segundo métodos descritos pelo Standard Methods for examination of Water and Wastewater (APHA, 1998). As análises de alcalinidade como $\mathrm{CaCO}_{3}$ foram feitas segundo a metodologia descrita por RIPLEY et al. (1986).

Em três períodos diferentes ao longo do experimento, foram analisados os sólidos em suspensão voláteis aderidos à espuma de poliuretano após desprendimento de biomassa do suporte por agitação manual em frascos contendo pérolas de vidro.

Para a determinação de formaldeído foi utilizado o método colorimétrico de BAILEY \& RANKIN (1971). A solução tampão de fosfato dissódico-ácido cítrico (Solução de Mcllvaine) para pH de 5,6 (ASSUMPÇÃO \& MORITA, 1968), foi preparada pela mistura das soluções de 17,647 g de ácido cítrico $\left(\mathrm{C}_{6} \mathrm{H}_{8} \mathrm{O}_{7}\right)$ em $840 \mathrm{~mL}$ de água destilada e 41,329 g de fosfato dissódico $\left(\mathrm{Na}_{2} \mathrm{HPO}_{4}\right)$ em $1160 \mathrm{~mL}$ de água destilada, armazenando-a em frasco escuro de $2 \mathrm{~L}$, à temperatura ambiente. O preparo da solução a $1 \%$ de dicloreto de $p$ fenilenodiamina $\left(\mathrm{C}_{6} \mathrm{H}_{8} \mathrm{~N}_{2} \cdot 2 \mathrm{HCl}\right)$ exigiu purificação prévia, uma vez que o composto apresentava tonalidade castanho claro. A purificação foi feita pela cristalização a partir de solução diluída de $\mathrm{HCl}$ (60 mL de $\mathrm{HCl}$ e $40 \mathrm{~mL}$ de água destilada) e 2 g de $\mathrm{SnCl}_{2}$. Após o aquecimento, foi adicionado carvão ativado e igual volume de $\mathrm{HCl}$ concentrado, resfriandose a seguir em banho de gelo e sal. Os cristais foram filtrados em papel, lavados com pequena quantidade de $\mathrm{HCl}$ e secados a vácuo, em dessecador, sobre $\mathrm{NaOH}$. Após cerca de dois dias, os cristais estavam secos para o preparo da solução. Para isso, dissolveu-se 1,0 g da substância em água destilada, em balão volumétrico de $100 \mathrm{~mL}$, transferindo-se para vidro escuro e conservando-se em geladeira. O restante da substância purificada permaneceu em freezer $\left(-17^{\circ} \mathrm{C}\right)$ e foi utilizada para o preparo das soluções ao longo do experimento. Sempre se preparou somente $100 \mathrm{~mL}$ para manter a qualidade, uma vez que em contato com o ar torna-se amarelada, alterando a leitura colorimétrica. O terceiro reagente, peróxido de hidrogênio $\left(\mathrm{H}_{2} \mathrm{O}_{2}\right.$ a 30\%), foi adquirido com qualidade P.A. e conservado em geladeira.

No procedimento analítico sugerido pelo método, adiciona-se, em frascos volumétricos de $100 \mathrm{~mL}$, os reagentes na ordem a seguir: 10,0 mL da solução tampão, 1,0 
$\mathrm{mL}$ da solução de $p$-fenilenodiamina e 5,0 mL de peróxido de hidrogênio, completando-se com a amostra até o volume de $100 \mathrm{~mL}$. Pela pequena quantidade de amostra que se pode coletar no reator durante os ensaios de perfil, optou-se por trabalhar com balão de 50,0 mL, utilizando-se a metade do volume de cada reagente. Após a dosagem dos reagentes, a solução era transferida para frascos de vidro incolor, sendo tampados com rolha de borracha, permanecendo em repouso por 20 min após a adição de $\mathrm{H}_{2} \mathrm{O}_{2}$, para se fazer a leitura. Todos os tempos foram cronometrados, pois a reação continua após os $20 \mathrm{~min}$, produzindo resultados irreais. Conforme indicação do método, a curva de calibração foi feita para as concentrações entre 0,50 e 2,50 mg/L de formaldeído (Figura 4.2), em duplicata. Foram feitas várias curvas de calibração ao longo do experimento, à medida que se substituía algum dos reagentes. Para a leitura das amostras foi utilizado espectrofotômetro DR 4000 $\mathrm{HACH}$, com cubeta de quartzo de 1,0 cm. O comprimento de onda utilizado foi de $420 \mathrm{~nm}$, encontrado durante a varredura, enquanto o sugerido pelo método é de $485 \mathrm{~nm}$. Os brancos foram preparados com água destilada e os três reagentes, com o mesmo tempo de 20 min para a leitura.

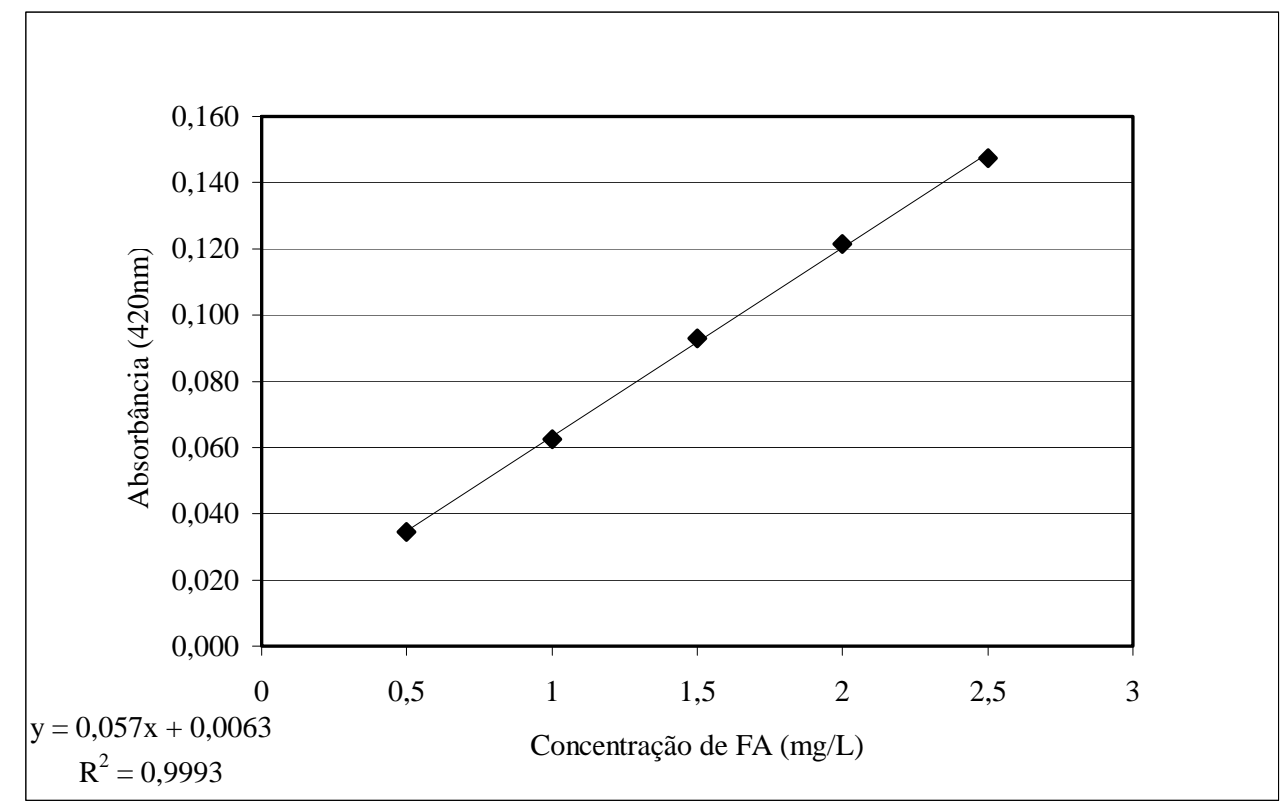

Figura 4.2: Curva de calibração para determinação da concentração de formaldeído pelo método de BAILEY \& RANKIN, 1971.

Foram feitos testes de absorbância com o meio Angelidaki a fim de se avaliar a sua interferência na leitura em comprimento de onda de $420 \mathrm{~nm}$ com soluções com várias diluições, próximas às utilizadas durante o experimento. Os resultados indicaram não haver tal interferência. 
Para as análises do afluente e efluente foi necessário se fazer diluições em balões volumétricos até a faixa de concentração do método.

A composição dos gases gerados pela degradação anaeróbia foi monitorada por cromatografia gasosa utilizando-se cromatógrafo Gow-Mac, com detector de condutividade térmica, e coluna “Porapak Q” ( $2 \mathrm{~m}$ x 1/4” - 80 a 100 mesh). O gás de arraste foi o hidrogênio a $1 \mathrm{ml} . \mathrm{s}^{-1}$. Para se medir a produção de gás foi instalado um sistema de vasos comunicantes, com erlenmeyer de $500 \mathrm{~mL}$ e pipeta graduada de $50 \mathrm{~mL}$, após o selo hídrico do reator.

A vazão média de alimentação do reator foi medida três vezes por semana, através de proveta de 10,0 mL e cronômetro, em triplicata.

A análise microbiológica do lodo foi realizada por microscopia ótica utilizando microscópio Olympus modelo BH2. Foram feitas análises do lodo em estado inicial (substrato à base de fenol) e das concentrações médias de formaldeído de 26,2 mg/L a 1158,6 mg/L. Também foram analisados os microorganismos presentes na mangueira de alimentação do reator, durante a concentração de 400 mg/L de formaldeído.

As fotografias do reator foram feitas com máquina Nikon F3, com objetiva microNIKKOR 55mm 1:28, a uma distância aproximada de $10 \mathrm{~cm}$, com filme ASA 400 e flash.

As análises de ácidos voláteis, por cromatografia gasosa, foram realizadas em cromatógrafo HP 6891, com detector de ionização de chama (FID), coluna HP INNOWAX, $30 \mathrm{~m} \times 0,25 \mathrm{~mm} \times 0,25 \mu \mathrm{m}$. O gás de arraste foi $\mathrm{H}_{2}$; fluxo de $2,0 \mathrm{~mL} / \mathrm{min}$. A temperatura do forno foi de $100^{\circ} \mathrm{C}(3 \mathrm{~min})$ a $180^{\circ} \mathrm{C}(5 \mathrm{~min}), 5^{\circ} \mathrm{C} / \mathrm{min}$. Temperatura do injetor: $250^{\circ} \mathrm{C}$, razão de split 1:20. Temperatura do detector: $300^{\circ} \mathrm{C}$; fluxo de ar sintético: $300 \mathrm{~mL} / \mathrm{min}$; fluxo de $\mathrm{N}_{2}$ (gás auxiliar): $33 \mathrm{~mL} / \mathrm{min}$; fluxo de $\mathrm{H}_{2}: 30 \mathrm{~mL} / \mathrm{min}$. Extração em frasco de vidro, com fechamento hermético, foram colocados: $2 \mathrm{~mL}$ de amostra $+\sim 1,0 \mathrm{~g} \mathrm{NaCl}+100 \mu \mathrm{L}$ de solução $\mathrm{H}_{2} \mathrm{SO}_{4} 1 \mathrm{M}+100 \mu \mathrm{L}$ de solução de ácido crotônico a $700 \mathrm{mg} / \mathrm{L}+$ 0,6 mL de éter etílico. Foi efetuada a agitação por 1 minuto em vórtex, seguida de centrifugação a 3000 rpm. Então, as amostras foram colocadas em freezer, juntamente com a micro-seringa. Foi injetado $1,0 \mu \mathrm{L}$ da fase etérea.

As análises de ácido fórmico, acético, lático e butírico foram realizadas em Sistema de CLAE (cromatografia líquida de alta eficiência) Shimadzu; bomba LC-10 AD VP; seletor de UV com arranjo de diodo, SPDM10A VP; coluna Aminex 874 - 300 x 7,8 mm; fase móvel: $\mathrm{N}_{2} \mathrm{SO}_{4}$ 0,005 M; fluxo: 0,6 mL/min; temperatura do forno: $35^{\circ} \mathrm{C} ; \lambda: 210 \mathrm{~nm}$. Para o preparo das amostras foi apenas utilizada a filtração, através de membrana de 0,45 $\mu$ e diluição. 


\subsection{Procedimento Experimental}

\subsubsection{Reativação da atividade da biomassa no reator}

O reator anaeróbio horizontal de leito fixo utilizado neste trabalho foi alimentado por cerca de um ano com fenol como fonte única de carbono (BOLAÑOS, 2001) em Meio Angelidaki (Tabela 4.1). No inóculo inicial, os sólidos totais foram de 81,4 g/L, sendo 22,2 g/L de fixos e 59,3 g/L de voláteis. As concentrações de fenol utilizadas no experimento variaram de $50 \mathrm{mg} / \mathrm{L}$ a $1200 \mathrm{mg} / \mathrm{L}$. O tempo de duração médio entre cada condição de concentração foi de cerca de um mês, quando o reator atingia estabilidade com eficiências acima de 95\%, para todas as concentrações estudadas. O TDH foi de 12 horas e a temperatura da câmara foi mantida em $30 \pm 1^{\circ} \mathrm{C}$.

Após o término dos experimentos com fenol, o reator ficou cerca de 3 meses sem alimentação, na própria câmara, porém em temperatura ambiente. O lodo não perdeu totalmente a umidade, mas sua cor passou para um tom marrom claro, conforme a Figura 4.3.

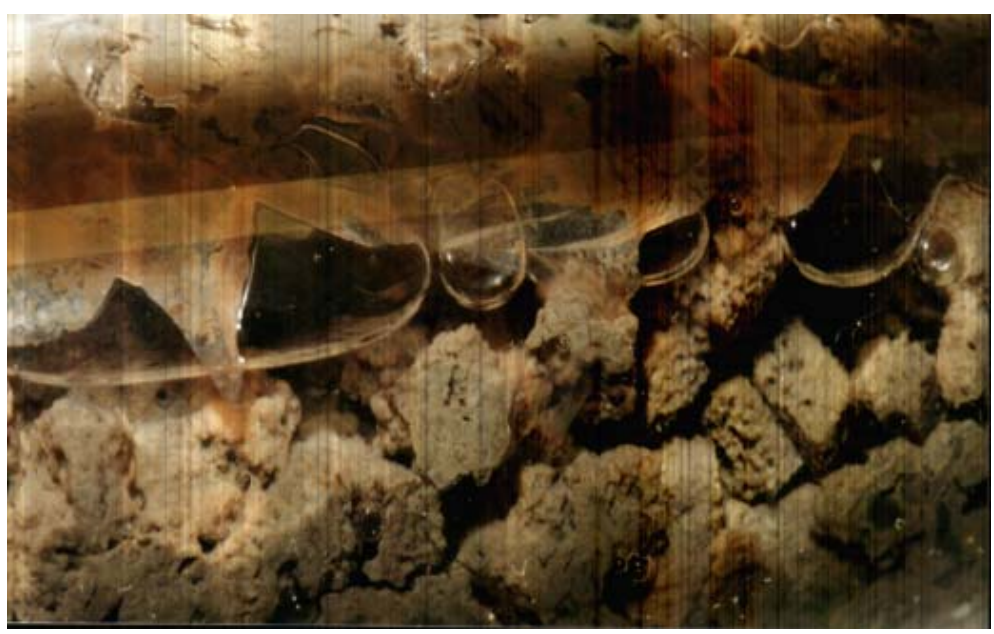

Figura 4.3: Situação do lodo do RAHLF após cerca de três meses sem alimentação.

Durante cerca de três meses, período de preparo e teste das metodologias para análise de formaldeído, o reator foi alimentado com fenol, em concentração aproximada de 50 mg/L e meio Angelidaki, e operado com TDH de 12 horas para recuperação da atividade da biomassa. Nesse período, os únicos monitoramentos foram da temperatura da câmara e da vazão. Após 20 dias de reativação do reator, já se pôde notar a tonalidade mais escura do lodo, conforme a Figura 4.4. 


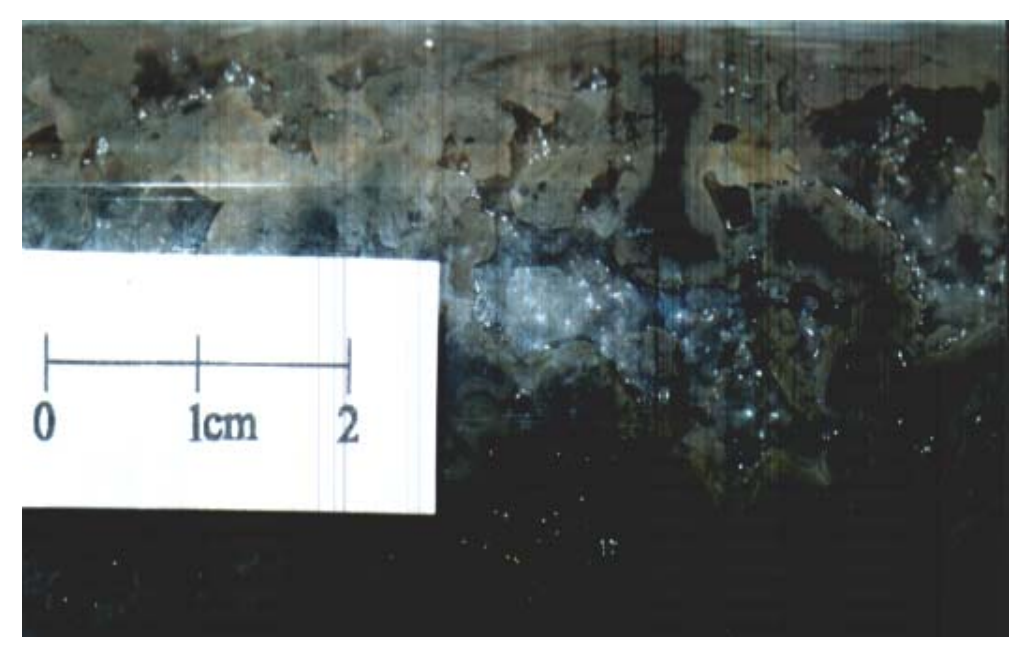

Figura 4.4: Situação do lodo do RAHLF após 20 dias de reativação, com substrato à base de formaldeído.

\subsubsection{Operação do RAHLF}

No estudo com formaldeído, a câmara do reator foi mantida a uma temperatura de $35^{\circ} \mathrm{C} \pm 1^{\circ} \mathrm{C}$, a fim de possibilitar a comparação dos resultados com a bibliografia citada. $\mathrm{O}$ reator foi operado com tempo de detenção hidráulica de 12,0 \pm 0,5 h, com base no volume útil do reator, com uma vazão aproximada de $66,7 \mathrm{~mL} / \mathrm{h}$. O sistema de mangueiras inicial foi de silicone. No entanto, com menos de 2 dias após a limpeza e substituição, havia a proliferação de microorganismos de cor rosada, até os ensaios com concentração de formaldeído de $600 \mathrm{mg} / \mathrm{L}$. Por esse motivo optou-se pelas mangueiras de tygon no trajeto entre o frasco de substrato e o início do reator. Isso fez com que houvesse menor agregação destes microorganismos durante o experimento.

Os experimentos foram realizados com o aumento progressivo da concentração de formaldeído, iniciando-se com uma média de $26,2 \mathrm{mg} / \mathrm{L}$ e chegando-se a uma média de 1416,8 mg/L. Os incrementos na concentração de formaldeído foram efetuados após a estabilização do sistema em cada condição.

O sistema foi considerado estabilizado após obtenção de valores constantes de concentração de formaldeído no efluente do reator. Após o regime de equilíbrio dinâmico ser atingido, foram realizadas amostragens nos pontos intermediários do reator ( $\mathrm{L} / \mathrm{D}=4,8,12$ e 16) para obtenção dos perfis de concentração de formaldeído. Os perfis ao longo do reator foram obtidos com a finalidade de otimização do sistema através da verificação do tempo de 
detenção realmente necessário para degradação do formaldeído e para obtenção dos parâmetros cinéticos de degradação do tóxico. Logo após a obtenção dos perfis, a concentração de formaldeído afluente era alterada. Todos os perfis foram feitos em duplicata, com 2 dias de intervalo entre as coletas.

A coleta de amostras do efluente foi feita em frascos plásticos com tampa, sendo necessário um volume de aproximadamente $100 \mathrm{~mL}$ por dia de análise. Todas as análises, exceto de ácidos voláteis, foram feitas logo após a coleta.

Para a amostragem dos pontos intermediários do reator, foi desenvolvido um método que procurou eliminar as amostras não representativas. Isso foi necessário porque ao se coletar líquido nesses pontos um volume de cerca de $30 \mathrm{~mL}$, suficiente para as análises de formaldeído, observou-se que a concentração de formaldeído medida era muito pequena, por vezes menor que a do efluente. Ao se efetuar uma segunda coleta no mesmo ponto, conseguia-se a leitura de uma concentração maior. Procedeu-se, então do seguinte modo: após a coleta normal do efluente, eram coletados cerca de 20 a $30 \mathrm{~mL}$ de cada ponto, do final para o início do reator, praticamente secando o líquido em torno de cada amostrador. Essas amostras eram desprezadas. Em seguida, esperava-se até que o efluente voltasse a gotejar, o que ocorria cerca de 40 min após essa primeira coleta. Então se procedia à coleta real, retirando-se em média $30 \mathrm{~mL}$ por ponto, do final para o início do reator, aguardando entre cada coleta o gotejamento do efluente (cerca de $20 \mathrm{~min}$ ). As coletas foram feitas com agulha especial para aplicação de anestesia na coluna vertebral, uma vez que possuem um filamento interno para limpeza, no caso de entupimento. Para as análises de formaldeído, as amostras dos pontos intermediários do reator foram filtradas através de membrana GF-52C da SS com $1,2 \mu \mathrm{m}$ de abertura, para se retirar a biomassa.

A coleta do biogás foi feita na mangueira de saída de gás para o selo hídrico, sendo necessário pressionar as mangueiras superiores de gás junto ao reator, antes da coleta, para que o líquido ali contido fluísse e possibilitasse o escoamento do gás.

Para as análises de ácidos voláteis e metabólitos, amostras do efluente e dos perfis, foram mantidas em freezer a $-17^{\circ} \mathrm{C}$.

Os monitoramentos de DQO, concentração de formaldeído, $\mathrm{pH}$, alcalinidade, composição do biogás e vazão foram feitos três vezes por semana, bem como a substituição do substrato. As análises de sólidos do efluente foram feitas semanalmente. O monitoramento foi efetuado para todos os ciclos, exceto para o de 1416,8 mg/L de formaldeído afluente médio, quando só se avaliou o perfil de formaldeído e metabólitos.

Para se investigar a presença de formaldeído no biogás, foi feito um ensaio utilizando-se o mesmo método de determinação de formaldeído (BAILEY \& RANKIN, 
1971). A concentração afluente do reator era de $30 \mathrm{mg} / \mathrm{L}$. Foram adicionados os reagentes à água destilada e $5 \mathrm{~mL}$ de biogás no balão volumétrico, fazendo-se a leitura após 20 minutos.

Para análise da biomassa por microscopia, foram retiradas espumas próximo à entrada do reator para cada concentração a partir de 175,9 mg/L de formaldeído afluente. No experimento com concentração afluente média de 808,0 mg/L foram adicionadas 5 cubos de espuma para reposição dos retirados, evitando modificações no escoamento.

\subsubsection{Estudos cinéticos}

Para avaliação do comportamento cinético da degradação do formaldeído, pela via anaeróbia, foram utilizados os perfis espaciais de concentração do tóxico obtidos para cada concentração afluente testada. Para cada perfil obtido, foi ajustada uma função de concentração de formaldeído em meio líquido, em função da relação adimensional entre comprimento e diâmetro do reator (L/D). A partir dessa função ajustada, foi possível a obtenção das velocidades de consumo de formaldeído através do balanço material no reator, considerando modelo de reator tubular ideal, conforme proposto por NARDI et al. (1999).

Esse método foi adaptado do original proposto por ZAIAT \& FORESTI (1997), utilizando método diferencial (SILVEIRA, 1996) e desenvolvido especificamente para estimativa dos parâmetros cinéticos em reatores de leito fixo. No método original, apenas um perfil de concentração é suficiente para a estimativa dos parâmetros cinéticos. As velocidades são avaliadas em diversas posições ao longo do reator, ou seja, para diversos L/D. No entanto, neste trabalho foram apenas obtidas as velocidades máximas (velocidades iniciais) para cada concentração aplicada, avaliadas em L/D igual a zero, permitindo uma análise mais precisa e minimizando erros de estimativa dos parâmetros cinéticos. Dessa forma, para cada perfil de concentração foi obtida apenas uma velocidade de reação, correspondente à concentração afluente aplicada. Esse método é uma particularidade do método diferencial e é denominado método das velocidades iniciais.

De acordo com SILVEIRA (1996), o método das velocidades iniciais para estimativa dos parâmetros cinéticos é mais preciso que o método diferencial simples, pois utiliza as velocidades iniciais e as concentrações correspondentes. 


\subsubsection{Destino final do efluente do reator e resíduos de análises}

Todo o efluente do reator e os resíduos das análises de determinação de formaldeído foram encaminhados para o Laboratório de Resíduos Químicos do Campus de São Carlos (LRQ). O dicloreto de p-fenilenodiamina utilizado na determinação de formaldeído é uma substância tóxica (MSDS, 2000-a), exigindo cuidados na sua estocagem, manuseio e descarte. Os resíduos de análise de DQO dos laboratórios já são enviados para o LRQ rotineiramente. Para o descarte do tambor do efluente do reator para envio ao LRQ, foi feita análise da concentração de formaldeído, para preenchimento no rótulo de identificação. 


\section{RESULTADOS E DISCUSSÃO}

\subsection{Ensaio de degradabilidade do substrato no frasco de alimentação}

Para se estudar a degradação do substrato à base de formaldeído no próprio recipiente de alimentação, foram feitas análises da DQO de amostras em várias concentrações a serem utilizadas no estudo, a saber: 30, 100, 200, 400, 800 e 1200 mg/L de formaldeído. Mediu-se a DQO no momento do preparo e posteriormente com 24 horas e 96 horas (Tabela 5.1). O ensaio foi feito em frascos de vidro transparente de $100 \mathrm{~mL}$, tampados e recobertos com filme plástico. Durante o estudo, os frascos foram mantidos dentro da câmara climatizada a $35^{\circ} \mathrm{C}$.

Tabela 5.1: Ensaio de degradabilidade do substrato.

\begin{tabular}{|c|c|c|}
\hline DQO Inicial (mg/L) & DQO após 24h $\quad(\mathrm{mg} / \mathrm{L})$ & DQO após 96h (mg/L) \\
\hline 53 & 51 & 49 \\
\hline 161 & 172 & 157 \\
\hline 287 & 305 & 285 \\
\hline 594 & 610 & 567 \\
\hline 1242 & 1192 & 1124 \\
\hline 1804 & 1965 & 1764 \\
\hline
\end{tabular}

Como pode se observar na Tabela 5.1, a remoção de DQO foi bem pequena ao longo das 96 horas nos frascos de teste do substrato. Esse experimento indicou que não seria necessário se autoclavar o meio para manter as características de alimentação em termos de DQO. No entanto, o teste não informou sobre a degradação específica do formaldeído ao longo de 96 horas no frasco. A pequena degradação de formaldeído no frasco ao longo de 96 horas pôde ser verificada ao longo da pesquisa.

Durante os experimentos, o substrato foi trocado três vezes por semana e mantido à temperatura ambiente, em frasco de vidro, recoberto com plástico escuro para minimizar o desenvolvimento de microorganismos fotossintetizantes. O reator também foi mantido coberto com tecido preto. 


\subsection{Avaliação do Desempenho do RAHLF}

\subsubsection{Remoção de DQO e Formaldeído}

O reator anaeróbio horizontal de leito fixo (RAHLF) foi operado durante 151 dias com substrato sintético à base de formaldeído. A Tabela 5.2 apresenta as concentrações médias de formaldeído afluente e efluente, com desvio padrão e número de amostras, durante o período de operação. Verificou-se uma pequena variação entre o formaldeído dosado e o medido através do método de BAILEY \& RANKIN (1971).

Tabela 5.2: Concentrações médias de formaldeído afluente e efluente, com desvio padrão e número de amostras, durante o período de operação.

\begin{tabular}{cccccc}
\hline $\begin{array}{c}\text { HCHO Afluente } \\
\text { Médio (mg/L) }\end{array}$ & $\begin{array}{c}\text { Desvio } \\
\text { Padrão }\end{array}$ & $\begin{array}{c}\text { Número de } \\
\text { Amostras }\end{array}$ & $\begin{array}{c}\text { HCHO Efluente } \\
\text { Médio (mg/L) }\end{array}$ & $\begin{array}{c}\text { Desvio } \\
\text { Padrão }\end{array}$ & $\begin{array}{c}\text { Número de } \\
\text { Amostras }\end{array}$ \\
\hline 26,2 & 3,1 & 16 & 3,0 & 0,7 & 13 \\
85,3 & 5,6 & 7 & 2,8 & 0,1 & 5 \\
175,9 & 16,5 & 8 & 2,7 & 0,3 & 7 \\
394,0 & 10,4 & 5 & 3,4 & 0,6 & 4 \\
597,7 & 2,4 & 4 & 3,4 & 0,4 & 4 \\
808,0 & 23,4 & 7 & 3,7 & 0,2 & 7 \\
989,2 & 20,8 & 7 & 3,8 & 0,3 & 7 \\
1158,6 & 29,8 & 8 & 3,8 & 0,3 & 7 \\
\hline
\end{tabular}

A Tabela 5.3 apresenta as concentrações médias de DQO afluente e efluente, com desvio padrão e número de amostras, e relação média de DQO/formaldeído do efluente durante o período de operação.

À medida que a concentração de formaldeído foi elevada na alimentação do reator, houve acréscimo gradual da DQO efluente (Figura 5.1). No entanto, a concentração média efluente de formaldeído aumentou muito pouco ao longo de todo estudo, apresentando média mínima de 2,73 \pm 0,31 mg/L quando a concentração afluente foi de 175,9 mg/L e média máxima de 3,79 \pm 0,30 mg/L para a concentração afluente de 989,2 mg/L. 
Tabela 5.3: Concentrações médias de DQO afluente e efluente, com desvio padrão e número de amostras, e relação média de DQO/formaldeído do efluente durante o período de operação.

\begin{tabular}{ccccccc}
\hline $\begin{array}{c}\text { DQO } \\
\text { Afluente } \\
\text { Média } \\
\text { (mg/L) }\end{array}$ & $\begin{array}{c}\text { Desvio } \\
\text { Padrão }\end{array}$ & $\begin{array}{c}\text { Número de } \\
\text { Amostras }\end{array}$ & $\begin{array}{c}\text { DQO } \\
\text { Efluente } \\
\text { Média (mg/L) }\end{array}$ & $\begin{array}{c}\text { Desvio } \\
\text { Padrão }\end{array}$ & $\begin{array}{c}\text { Número de } \\
\text { Amostras }\end{array}$ & $\begin{array}{c}\text { Relação } \\
\text { DQO/HCHO } \\
\text { Médio Efluente }\end{array}$ \\
\hline 51,6 & 5,1 & 9 & 13,7 & 4,3 & 7,0 & 4,6 \\
159,4 & 12,4 & 6 & 21,2 & 7,2 & 4,0 & 7,6 \\
315,8 & 7,0 & 6 & 22,6 & 3,3 & 5,0 & 8,3 \\
608,9 & 12,3 & 5 & 42,0 & 10,4 & 4,0 & 12,4 \\
930,0 & 17,0 & 4 & 48,9 & 2,3 & 4,0 & 14,3 \\
1238,5 & 9,5 & 7 & 90,8 & 15,2 & 7,0 & 24,4 \\
1494,1 & 40,4 & 5 & 99,7 & 20,8 & 7,0 & 26,3 \\
1798,5 & 17,2 & 6 & 99,2 & 17,4 & 5,0 & 26,3 \\
\hline
\end{tabular}

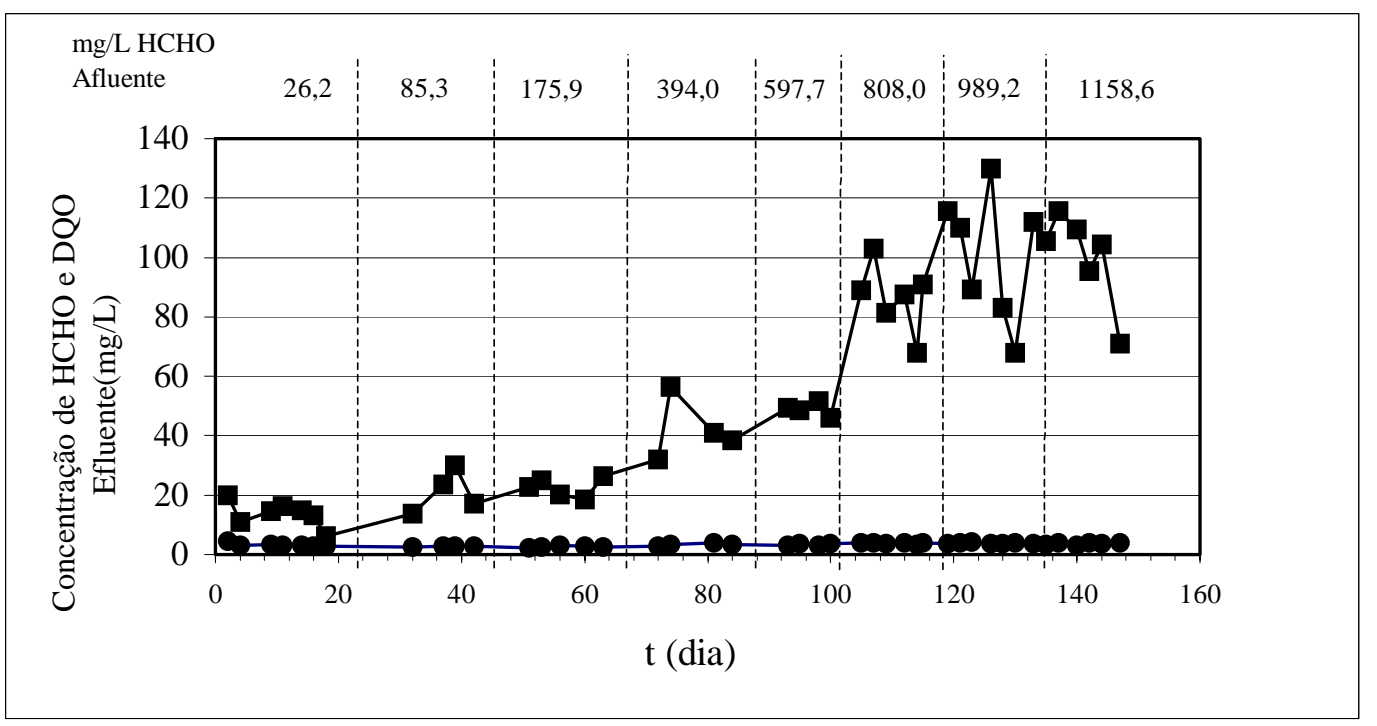

Figura 5.1: Variação temporal da concentração efluente de DQO (ロ) e formaldeído (•).

A Figura 5.2 apresenta a variação da eficiência de remoção de DQO e de formaldeído ao longo do tempo. A pequena instabilidade observada nos valores até aproximadamente o vigésimo dia de operação indica a rápida partida do sistema. Esta rápida partida pode estar associada à adaptação prévia do lodo em fenol (BOLAÑOS, 2001) e também à alta retenção de biomassa obtida geralmente em espuma de poliuretano.

A partir da aplicação de concentração afluente média de 175,9 mg HCHO/L, a eficiência de remoção de DQO permaneceu praticamente estável até o final do estudo (média 
de 92 \%). Entretanto, a eficiência de remoção de formaldeído aumentou a cada experimento, chegando a 99,7\% no último experimento (1416,8 mg/L de formaldeído afluente).

No entanto, deve ser ressaltado que a eficiência de remoção de formaldeído aumentou principalmente devido ao aumento da concentração afluente, pois a concentração efluente ficou praticamente constante ao longo de todo o estudo $(3,30 \pm 0,59 \mathrm{mg} / \mathrm{L})$.

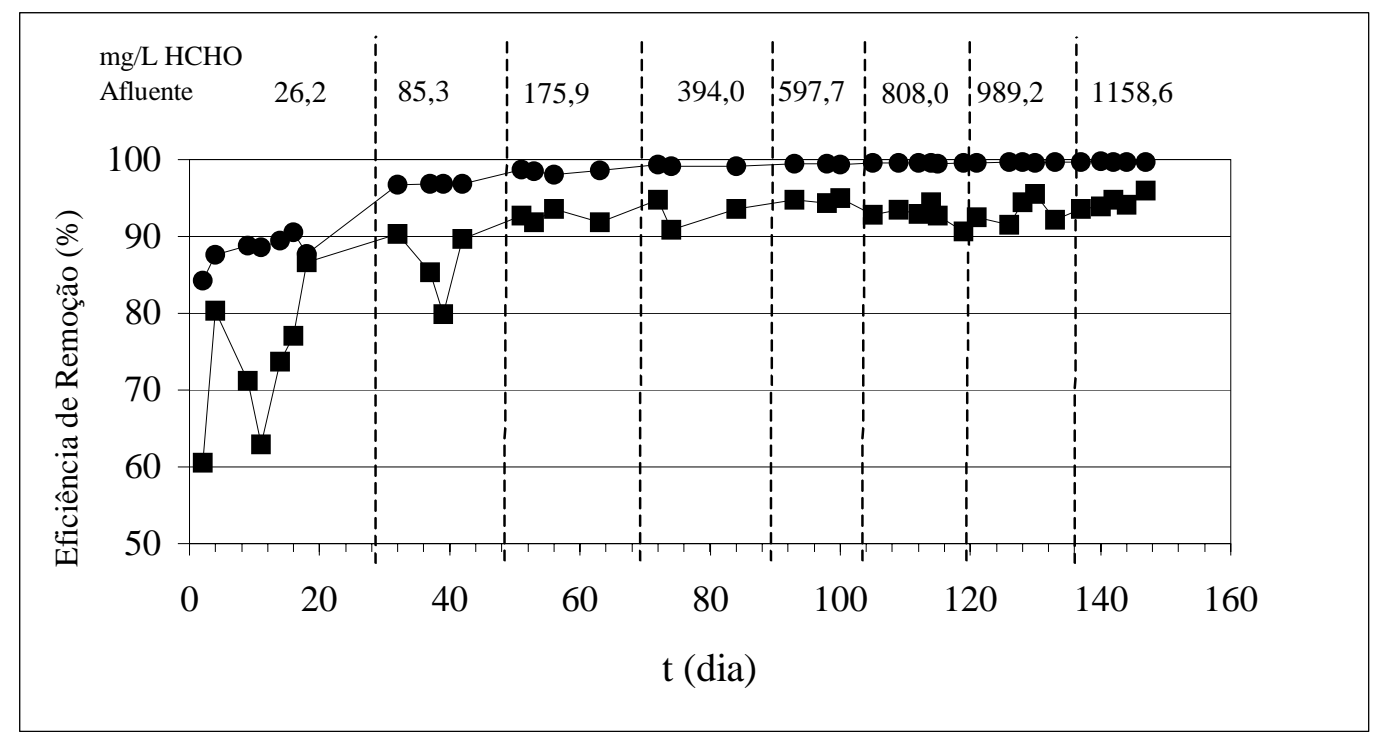

Figura 5.2: Variação temporal da eficiência de remoção de DQO (ロ) e de formaldeído (•).

A seguir, são comparados os comportamentos da concentração de formaldeído efluente do RAHLF com outros estudos em sistemas contínuos. Há poucos trabalhos que especificam a concentração efluente de formaldeído para as concentrações de formaldeído afluente: QU \& BHATTACHARYA (1997) (<1mg/L), ZOUTBERG \& DE BEEN (1997) ( $<20 \mathrm{mg} / \mathrm{L})$ e VIDAL et al. (1999) $(<50 \mathrm{mg} / \mathrm{L})$. No estudo de QU \& BHATTACHARYA (1997), a concentração de formaldeído efluente foi menor que $1 \mathrm{mg} / \mathrm{L}$ até a maior concentração afluente estudada, 1110 mg/L. ZOUTBERG \& DE BEEN (1997) apenas apresentam os dados sobre o sistema trabalhando com a concentração afluente de cerca de $333 \mathrm{mg} / \mathrm{L}$ de formaldeído, resultando um efluente com concentração de formaldeído menor que $20 \mathrm{mg} / \mathrm{L}$, sem reportar dados sobre concentrações afluentes superiores. Apenas VIDAL et al. (1999) apresentam dados do comportamento dos reatores para concentrações afluentes de formaldeído acima da considerada adequada para os sistemas. Os pesquisadores reportam que no UASB com substrato composto por formaldeído e glicose (R1), a concentração afluente de 2 g/L de formaldeído provocou queda na eficiência de remoção de DQO de 98 \% para $70 \%$, além de queda na alcalinidade total de 1,2 g $\mathrm{CaCO}_{3}$ para 0,4 g $\mathrm{CaCO}_{3}$. No 
entanto, em cerca de uma semana o reator voltou às condições anteriores de eficiência e concentração efluente de formaldeído. No UASB com substrato composto por formaldeído, uréia e glicose (R2), VIDAL et al. (1999) reportam um leve declínio da eficiência de remoção de DQO após a concentração considerada ideal para o sistema (380mg/L), chegando até $950 \mathrm{mg} / \mathrm{L}$ de formaldeído, sem que tenha havido aumento da concentração efluente de formaldeído. A alcalinidade total permaneceu sempre superior a 1,6 g $\mathrm{CaCO}_{3}$.

O comportamento praticamente constante da concentração de formaldeído efluente nos estudos de QU \& BHATTACHARYA (1997) e de VIDAL et al. (1999) é semelhante ao encontrado no RAHLF, embora, nesse último, não tenha havido nenhuma indicação de inibição do sistema até a concentração afluente de formaldeído de 1416,8 mg/L.

A Figura 5.3 apresenta a variação temporal da relação entre as concentrações de DQO e formaldeído afluente e efluente. A relação DQO/formaldeído afluente manteve-se praticamente constante durante todo o estudo (cerca de 1,7 $\pm 0,2$ ). No entanto, a mesma relação para o efluente cresceu gradualmente até o experimento com 808,0 mg/L de formaldeído afluente, mantendo-se instável nos últimos dois experimentos, com média de 26 \pm 9. Como a concentração de formaldeído variou pouco no efluente, esse acréscimo poderia estar associado à presença de ácidos e outros subprodutos, sólidos suspensos ou materiais de excreção celular no efluente. No entanto, as análises de amostras do efluente detectaram porcentagens muito baixas de ácidos graxos voláteis (item 5.2.5) e as análises de sólidos voláteis do efluente apresentaram resultados praticamente constantes (item 5.2.2) não justificando o aumento na relação DQO/formaldeído.

mg/L de HCHO

Afluente

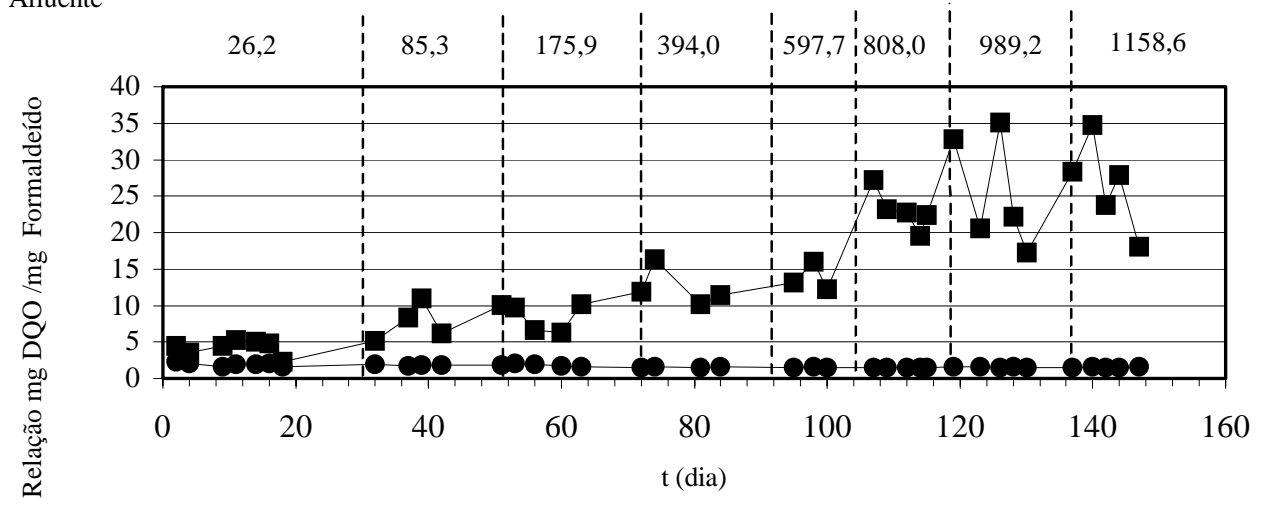

Figura 5.3: Variação temporal da relação mg DQO/mg formaldeído afluente $(\bullet)$ e

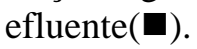


As Figuras 5.4 e 5.5 relacionam a carga orgânica removida expressa como carga de DQO e de formaldeído em função da carga orgânica aplicada. Para os dois parâmetros houve uma relação linear, indicando que não foi atingida a capacidade limite de remoção do sistema para as concentrações afluentes aplicadas.

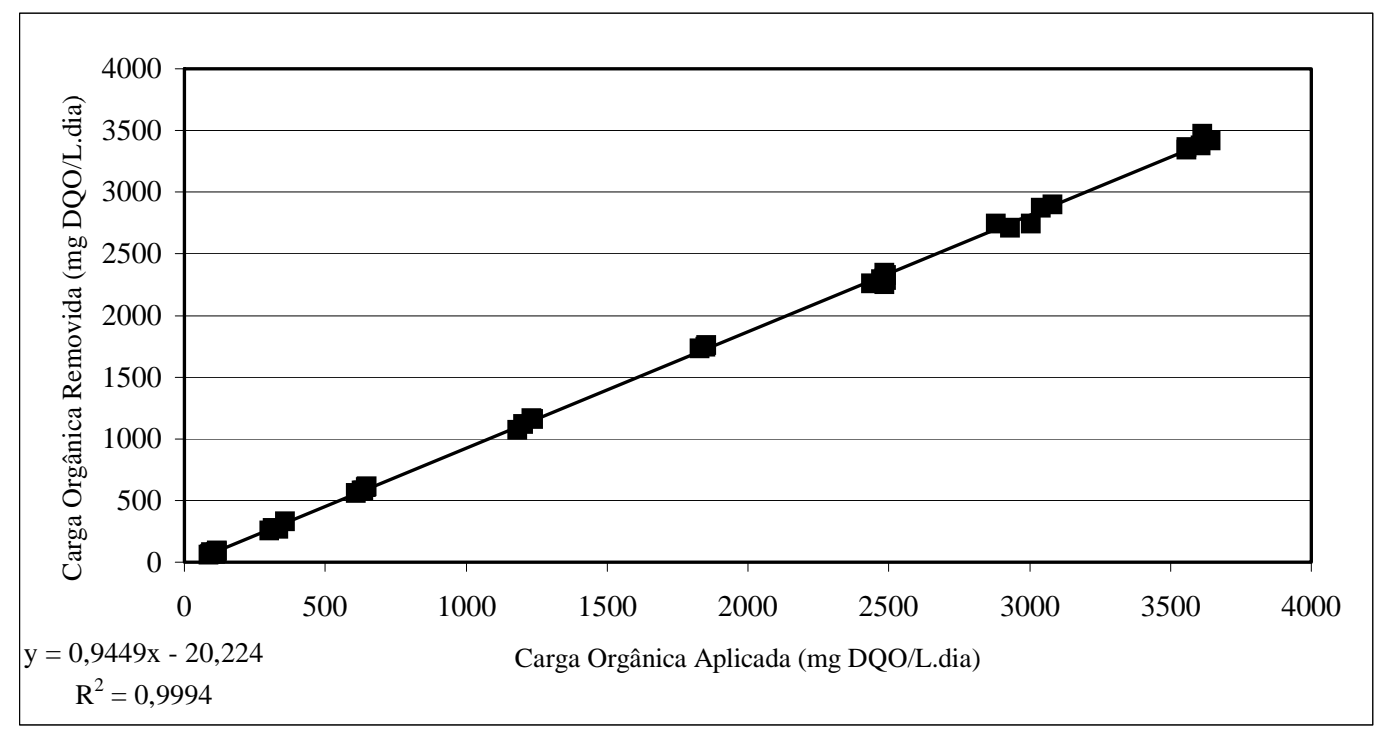

Figura 5.4: Variação temporal da carga orgânica de DQO removida em função da carga orgânica aplicada.

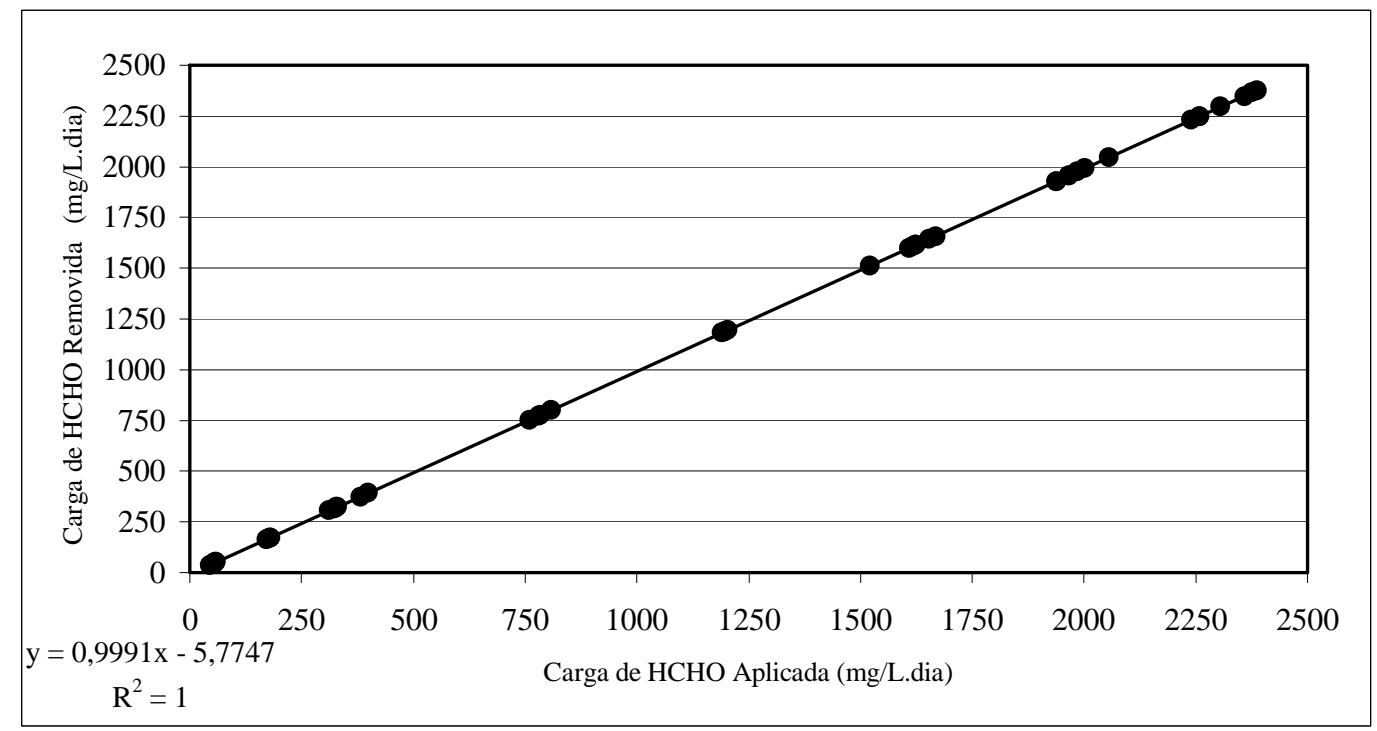

Figura 5.5: Variação temporal da carga orgânica de formaldeído removida em função da carga orgânica aplicada. 
Comparando-se as cargas orgânicas de formaldeído aplicadas de alguns trabalhos em sistemas contínuos (Tabela 5.4), verifica-se que no RAHLF foi possível a aplicação de uma carga superior aos demais sistemas, sem comprometimento do mesmo.

Tabela 5.4: Comparação entre as cargas de formaldeído aplicadas em alguns trabalhos com sistemas contínuos.

\begin{tabular}{|c|c|c|c|c|}
\hline Autores & Sistema & $\begin{array}{c}\text { Concentração } \\
\text { considerada } \\
\text { (mg HCHO/L) }\end{array}$ & $\begin{array}{l}\text { TDH } \\
\text { (dia) }\end{array}$ & $\begin{array}{c}\text { CO } \\
\text { Aplicada } \\
\text { (mg/L.dia) }\end{array}$ \\
\hline PARKIN et al. (1983) & Filtro Anaeróbio & 400 & 1 & 400,0 \\
\hline SHARMA et al. (1994) & $\begin{array}{c}\text { Tanque de agitação } \\
\text { contínua e partículas } \\
\text { de suporte para } \\
\text { biomassa }\end{array}$ & 375 & 10 & 37,5 \\
\hline $\begin{array}{c}\text { QU \& BHATTACHARYA } \\
\text { (1997) }\end{array}$ & Quimiostato & 1110 & 14 & 79,3 \\
\hline VIDAL et al. (1999) & $\begin{array}{l}\text { UASB (HCHO e } \\
\text { glicose) }\end{array}$ & 1000 & 0,62 & 1612,9 \\
\hline VIDAL et al. (1999) & $\begin{array}{l}\text { UASB (HCHO, uréia } \\
\text { e glicose) }\end{array}$ & 380 & 0,62 & 612,9 \\
\hline Esse trabalho & RAHLF & 1158 & 0,5 & 2316,0 \\
\hline
\end{tabular}

Para a avaliação da concentração de biomassa no reator ao longo do experimento, foram efetuadas análises de sólidos suspensos voláteis aderidos à espuma de poliuretano nos dias 102, 135 e 151 de operação, nas concentrações afluentes de 597,7, 989,2 e 1158,6 mg/L de formaldeído, respectivamente. As concentrações de SSV expressas por mL de espuma encontradas foram de 37,9, 52,5 e 44,0, respectivamente. A média foi de 44,8 \pm 7,3 mg SSV/mL espuma, muito próxima da média encontrada por BOLAÑOS (2001), 48 mg SSV/ml espuma, que é considerada a concentração de biomassa inicial desse trabalho. Dessa forma, pode-se considerar constante a biomassa aderida à espuma ao longo de todo o período experimental, como resultado do balanço entre crescimento e arraste da biomassa, apresentado no item 5.2.2. Essa observação pode ser feita devido aos possíveis erros na determinação de sólidos aderidos à espuma. A amostragem das partículas e a técnica de desprendimento da biomassa podem interferir no resultado final.

Com a concentração média de 44,8 mg SSV/mL de espuma, tem-se concentração de biomassa no reator de 26,88 g SSV/L, baseado no volume total do sistema. GONZALEZGIL et al. (1999) consideraram "alta concentração de biomassa” o valor de 23 g SSV/L, sendo que o RAHLF obteve concentração cerca de 17 \% superior. 
Considerando-se a carga aplicada de 2316 mg HCHO/L.dia, a carga específica equivalente será de 0,086 g HCHO/g SSV.dia.

Alguns autores avaliaram a carga específica em seus trabalhos. SHARMA et al. (1994) acharam que a maior carga de formaldeído para a estabilidade do processo foi de 0,05 g HCHO/g SSV. dia. No quimiostato de QU \& BHATTACHARYA (1997), a carga específica foi de 0,164 g HCHO/g SSV.dia. VIDAL et al. (1999) conseguiram a taxa de 0,6 g HCHO/g SSV.dia, com operação estável.

Embora a carga específica atingida por VIDAL et al. (1999) seja extremamente alta comparada com este e os demais trabalhos, o alto valor é apenas conseqüência de uma baixa concentração de biomassa no sistema, ou seja, aproximadamente 5 g SSV/L, cerca de 5 vezes menor que a observada nesse trabalho. Quando a comparação é feita em termos de carga aplicada, os valores são menores que a aplicada desse trabalho (ver Tabela 5.4).

Fazendo-se uma analogia com o trabalho de VIDAL et al. (1999), para se atingir a mesma CO específica no RAHLF (0,6 g HCHO/g SSV.dia) seria necessária a CO aplicada de aproximadamente 16 g HCHO/L.dia, o que daria uma concentração afluente de cerca de 8 g/L de formaldeído.

A alta concentração de biomassa do RAHLF pode representar uma segurança para o sistema em termos de sobrecarga ou outros fatores ambientais de interferência.

\subsubsection{Sólidos}

A variação da concentração de sólidos totais e sólidos voláteis totais do efluente, ao longo do experimento, foi muito discreta. Quanto à concentração de sólidos suspensos totais e voláteis do efluente, houve uma variação um pouco mais acentuada. A variação da concentração de sólidos no efluente ao longo do tempo está representada na Figura 5.6, para sólidos totais e sólidos voláteis totais, e na Figura 5.7, para sólidos suspensos totais e sólidos suspensos voláteis. 


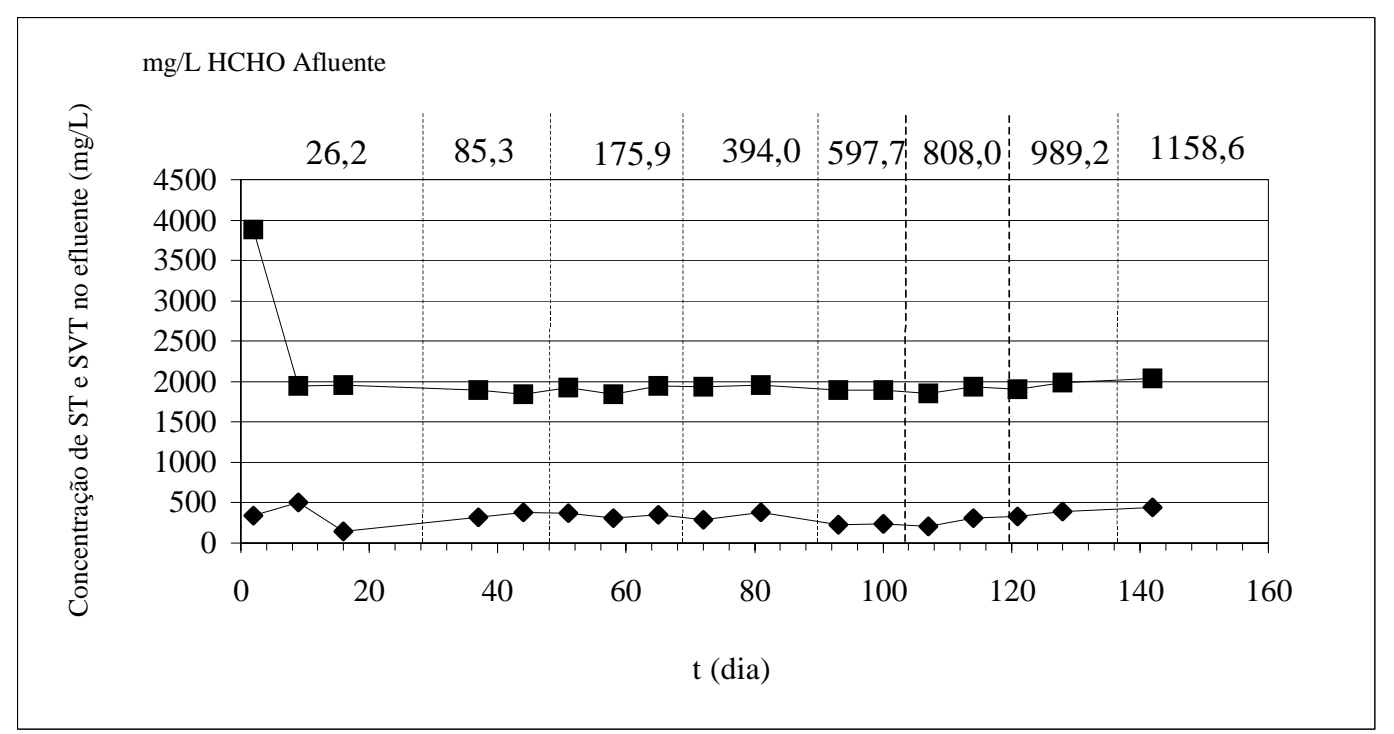

Figura 5.6: Variação temporal das concentrações de sólidos totais (घ) e sólidos voláteis totais ( $\bullet$ ) no efluente.

O arraste de biomassa no reator, expresso em SSV, foi de $93 \mathrm{mg}$ SSV/dia, causando um arraste de $14 \mathrm{~g}$ de SSV ao longo de todo o período experimental, cerca de $26 \%$ de um total de $54 \mathrm{~g}$ de SSV aderidos à espuma de poliuretano dentro do reator, durante os 151 dias de experimento. Entretanto, não houve variação significativa do SSV na espuma ao longo de todo o experimento, indicando que houve crescimento celular, de forma aproximada, proporcional à quantidade arrastada no período.

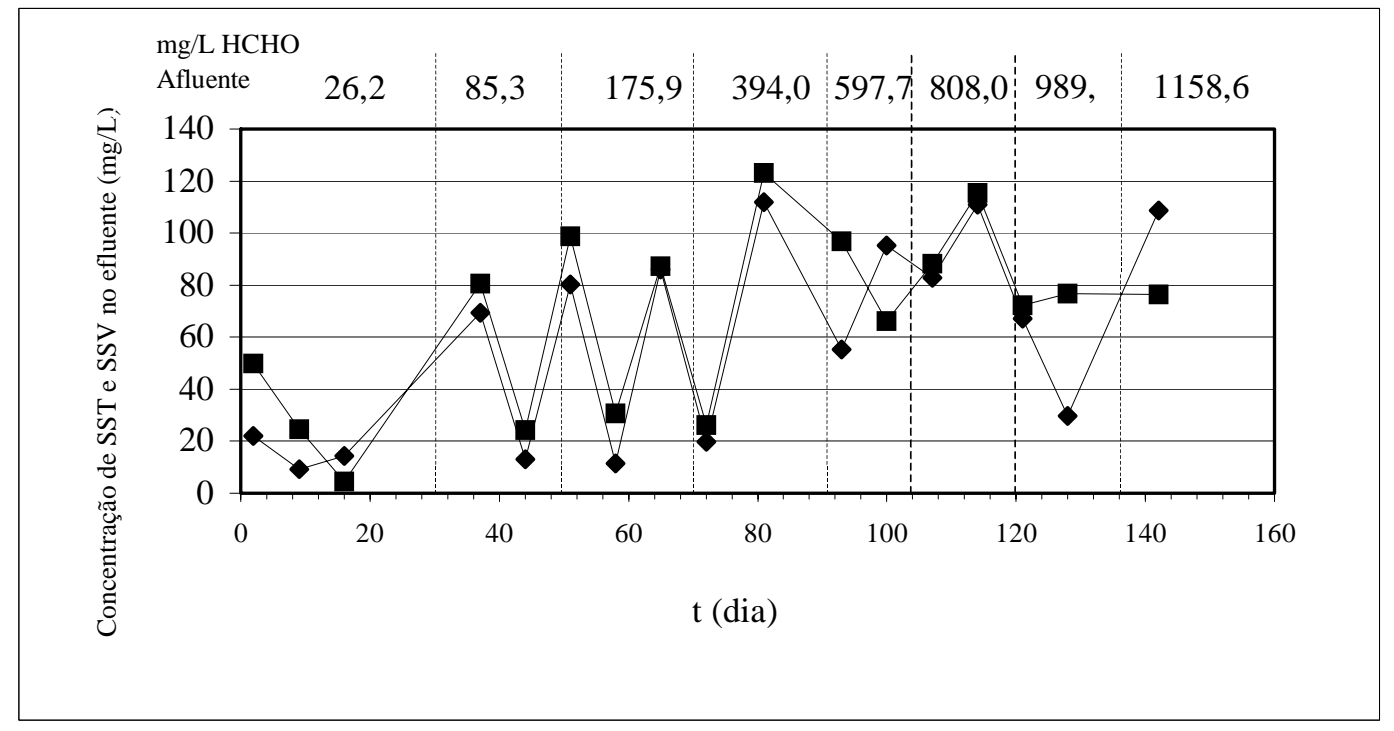

Figura 5.7: Variação temporal das concentrações de sólidos suspensos totais (অ) e sólidos suspensos voláteis $(\diamond)$ no efluente. 


\subsubsection{Alcalinidade e pH}

$\mathrm{O}$ pH do afluente e do efluente, bruto e filtrado, não sofreu variação significativa ao longo dos experimentos. Os valores do $\mathrm{pH}$ do afluente bruto foram de 7,6 $\pm 0,4$ e do filtrado de 7,7 $\pm 0,6$. Os valores do $\mathrm{pH}$ do efluente bruto foram de 7,9 $\pm 0,4$ e do filtrado de $8,0 \pm 0,7$.

As concentrações de alcalinidade total e parcial do afluente e do efluente sofreram um pequeno decréscimo com o aumento da concentração de formaldeído (Figura 5.8). No entanto, os valores do efluente são muito próximos aos do afluente. Isso indica que a produção de ácidos no decorrer da degradação não afetou o sistema, provavelmente devido à alta concentração de bicarbonato de sódio $(2$ g/L) do afluente ou à geração de alcalinidade nas reações de decomposição.

A relação entre alcalinidade intermediária/alcalinidade parcial não sofreu grandes variações em função do tempo (Figura 5.9), indicando a estabilidade do processo anaeróbio de conversão (RIPLEY et al., 1986).

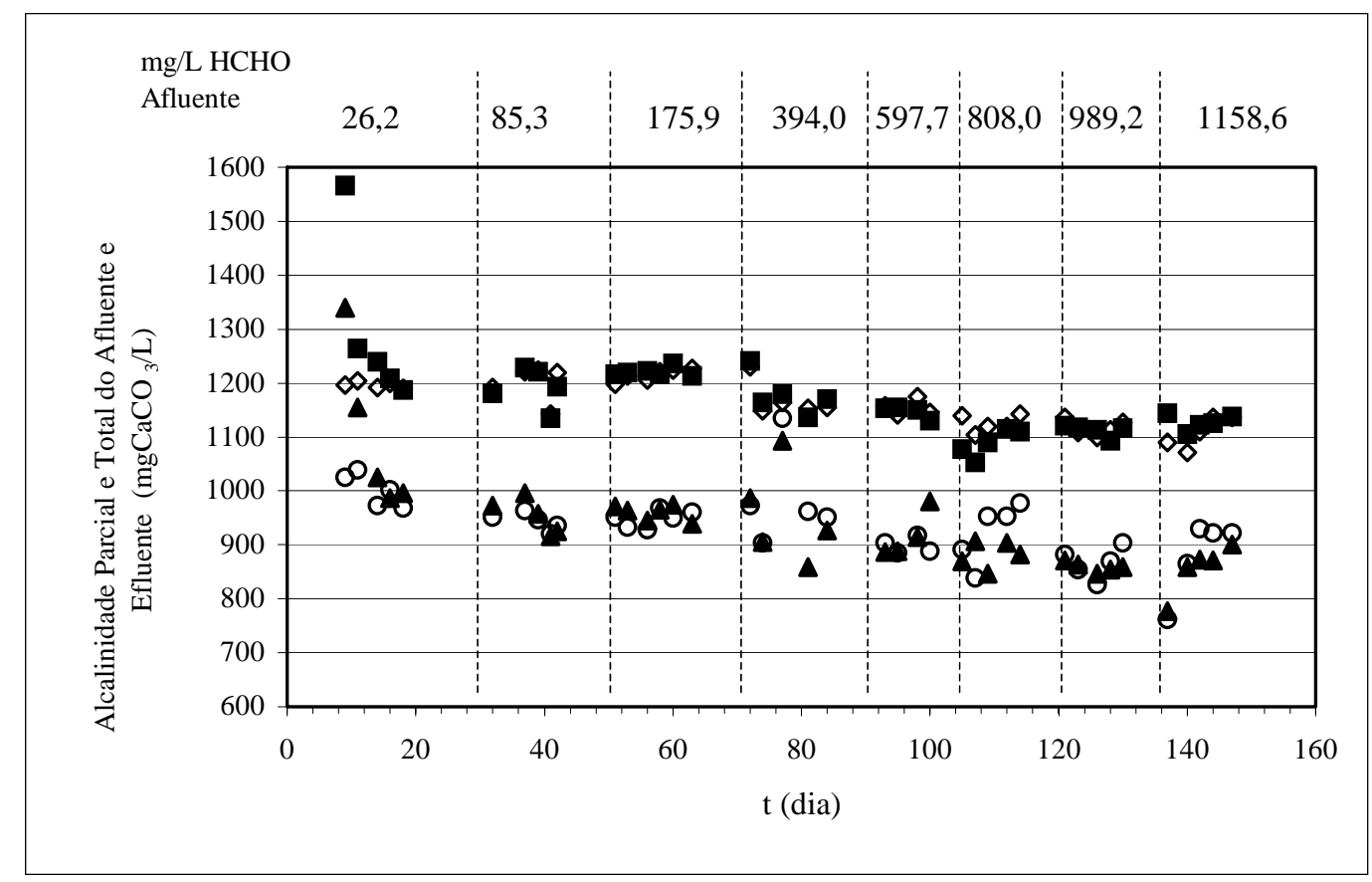

Figura 5.8: Variação temporal da alcalinidade total ( $\bullet$ ) e parcial $(\boldsymbol{\bullet})$ do afluente e total $(\diamond)$ e parcial $(O)$ do efluente. 


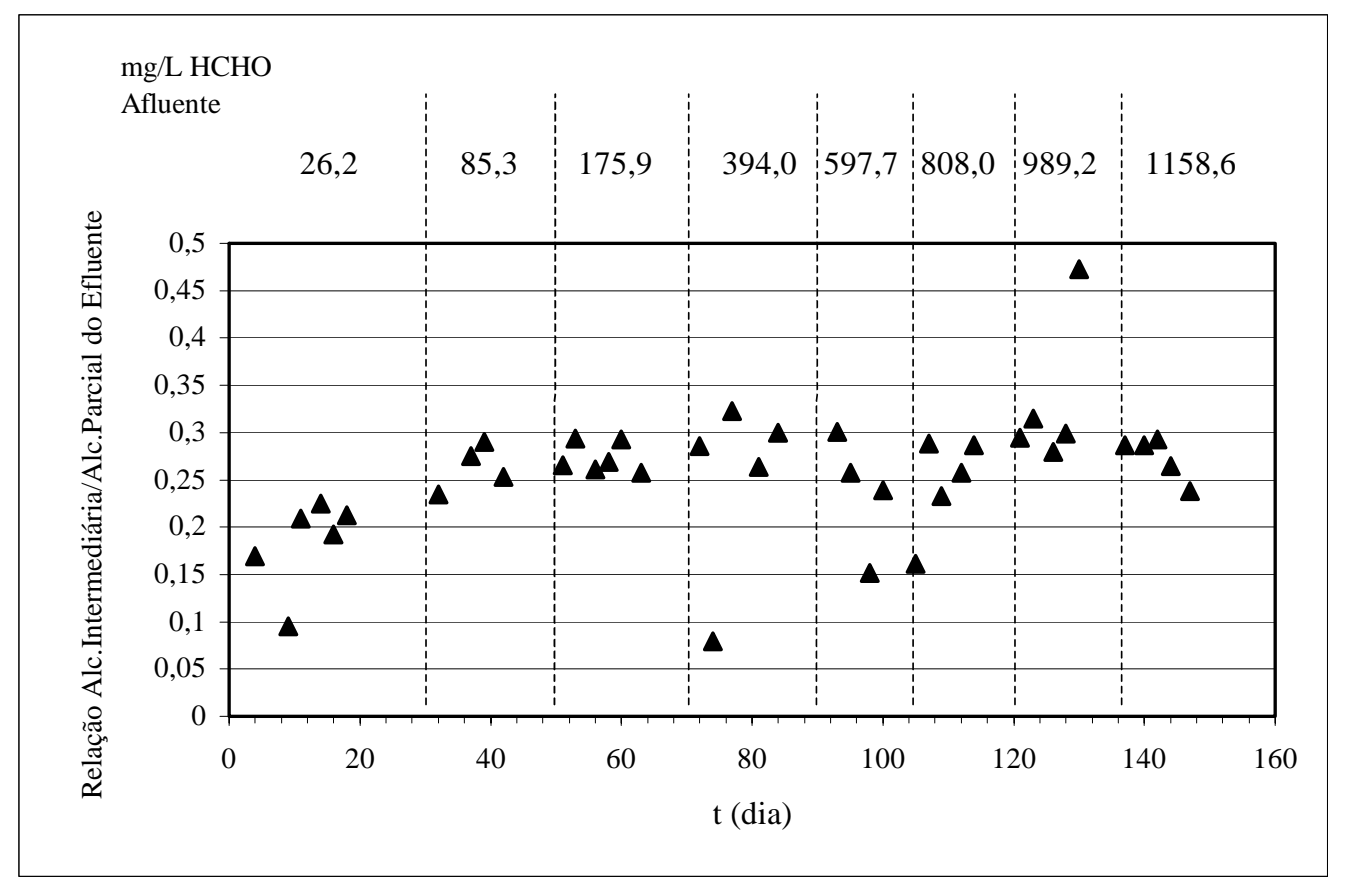

Figura 5.9: Variação temporal da relação alcalinidade intermediária/alcalinidade parcial do efluente $(\boldsymbol{\Delta})$.

\subsubsection{Biogás}

As concentrações de metano e dióxido de carbono no biogás sofreram aumento progressivo com o aumento da concentração de formaldeído afluente (Figura 5.10). As quedas na concentração de $\mathrm{CH}_{4}$ e $\mathrm{CO}_{2}$ observadas em algumas amostragens não são necessariamente devidos à inibição, pois as interferências da coleta de amostras para os perfis podem também ter contribuído para isso. No procedimento para essa coleta, descrito no item 4.4.2, era retirada grande parte do líquido do reator, modificando a relação entre biomassa e substrato. Durante a coleta do líquido com a seringa, certa quantidade de gás também era retirada, diminuindo a sua concentração no reator. Também deve ser considerado que uma pequena quantidade de ar era certamente aplicado ao reator, dado ao grande número de inserções da seringa nos septos, durante toda a amostragem.

As maiores concentrações de metano foram verificadas no experimento de 1158,6 mg/L, indicando que pode não ter havido inibição dos microorganismos metanogênicos. 


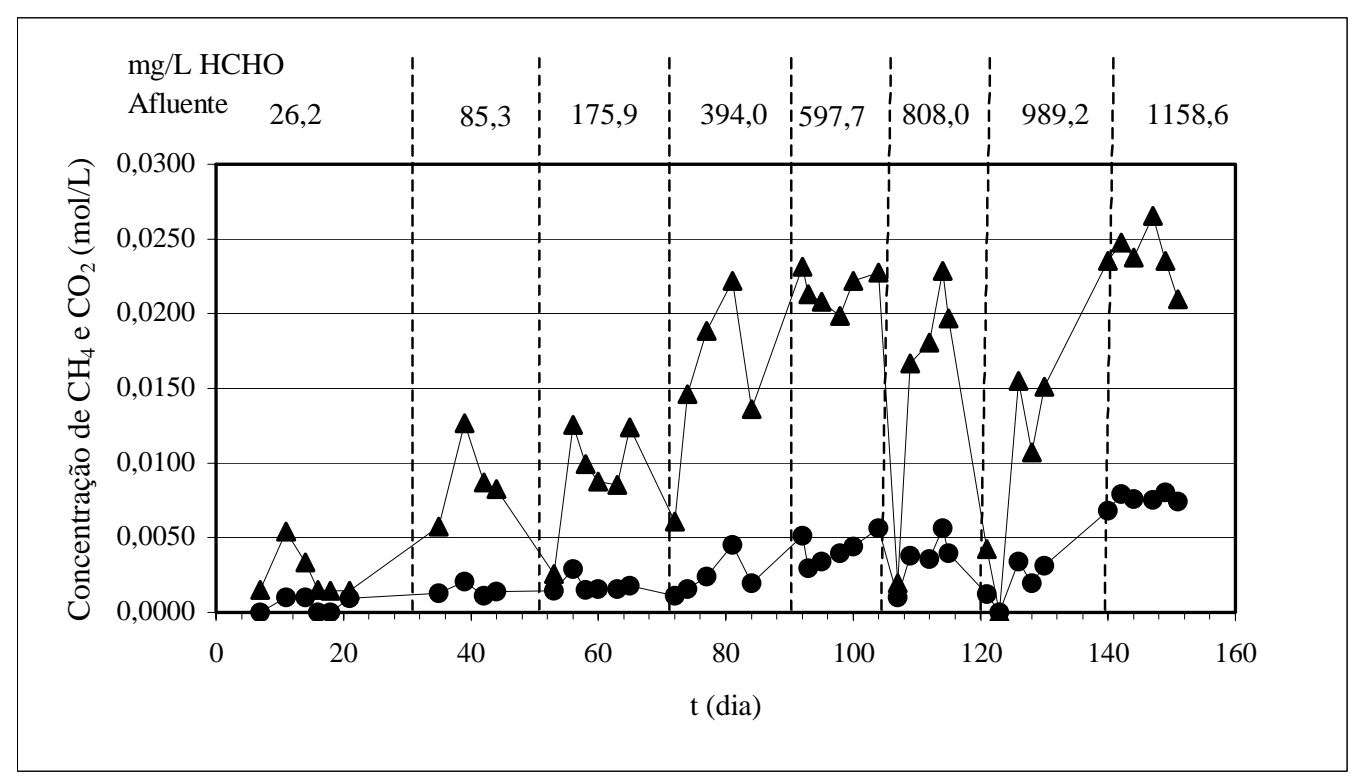

Figura 5.10: Variação temporal da concentração de $\mathrm{CH}_{4}(\boldsymbol{\Delta})$ e $\mathrm{CO}_{2}(\bullet)$.

A Figura 5.11 apresenta a variação temporal das porcentagens relativas de $\mathrm{CH}_{4} \mathrm{e}$ $\mathrm{CO}_{2}$. Há um discreto decréscimo da concentração de metano e acréscimo da produção de $\mathrm{CO}_{2}$. Embora tenha aumentado a concentração de $\mathrm{CO}_{2}$, não houve significativa variação do pH efluente.

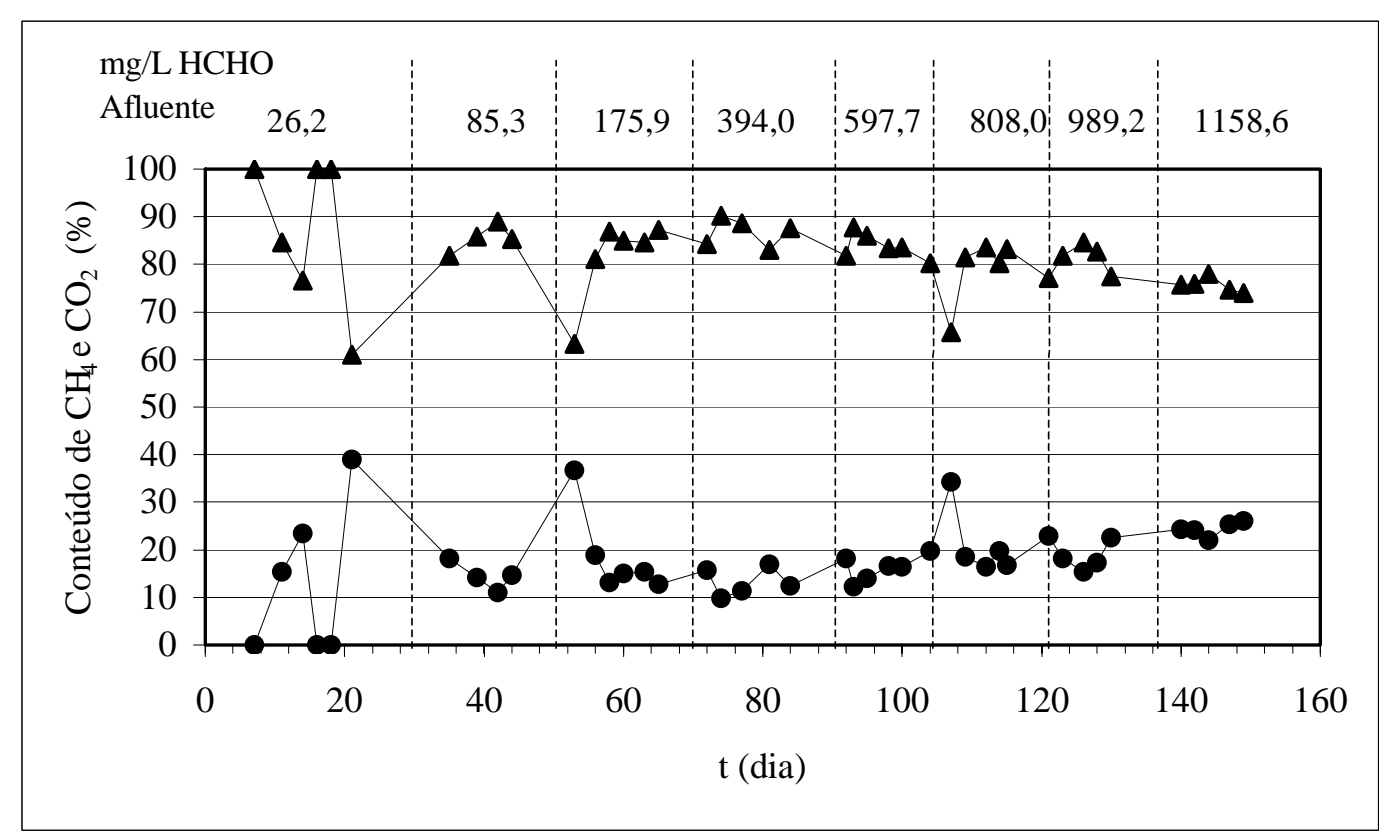

Figura 5.11: Variação temporal da porcentagem de $\mathrm{CH}_{4}(\boldsymbol{\bullet})$ e $\mathrm{CO}_{2}(\bullet)$. 
A Tabela 5.5 mostra a variação temporal média do conteúdo de $\mathrm{CH}_{4}$ no biogás em porcentagem e em mol/L. Embora tenha havido um decréscimo da porcentagem média de $\mathrm{CH}_{4}$, houve um progressivo aumento da concentração em mol/L, indicando que efetivamente maior quantidade de formaldeído foi convertida a metano.

Tabela 5.5: Variação temporal média do conteúdo de $\mathrm{CH}_{4}$ no biogás em porcentagem e em $\mathrm{mol} / \mathrm{L}$.

\begin{tabular}{ccc}
\hline $\begin{array}{c}\text { Concentração Média de } \\
\text { HCHO Afluente (mg/L) }\end{array}$ & \% $\mathbf{C H}_{\mathbf{4}}$ Média & $\begin{array}{c}\text { Concentração Média de } \mathbf{C H}_{\mathbf{4}} \\
(\mathbf{m o l} / \mathbf{L})\end{array}$ \\
\hline 26,2 & 87,0 & 0,0025 \\
85,3 & 85,5 & 0,0088 \\
175,9 & 81,3 & 0,0091 \\
394,0 & 86,8 & 0,0151 \\
597,7 & 84,5 & 0,0214 \\
808,0 & 79,0 & 0,0170 \\
989,2 & 80,8 & 0,0114 \\
1158,6 & 75,6 & 0,0244 \\
\hline
\end{tabular}

Para se medir a produção de gás foi instalado o dispositivo descrito no item 4.3. No entanto, após uma semana pôde ser lida apenas uma pequena variação no nível de água da pipeta, que se estabilizou nas outras semanas, sem se modificar. Esse sistema foi retirado uma vez que alterou a pressão interna do reator, fazendo com que diminuísse o volume de líquido no seu interior e tornasse irregular a vazão do efluente. As concentrações irregulares de metano e $\mathrm{CO}_{2}$ nos experimentos com concentração afluente de formaldeído de 808,0 mg/L e 989,2 mg/L podem estar relacionadas com as variações de vazão ocorridas durante esse período.

Foi analisada a presença de formaldeído no biogás para identificar possível volatilização do composto, conforme descrito no item 4.4.2, não se detectando, entretanto, a presença do aldeído na atmosfera do reator.

\subsection{5 Ácidos Voláteis do Efluente}

A presença de ácidos voláteis no efluente do reator só foi detectada nos experimentos com concentrações médias afluentes de formaldeído de 989,2 e 1158,6 mg/L. Pequena concentração de ácido acético de $20,4 \mathrm{mg} / \mathrm{L}$ foi detectada em amostra do 
experimento com 989,2 mg HCHO/L, por análise em HPLC. Para o experimento de 1158,6 mg HCHO/L, um valor ainda menor, de 9,23 mg/L de ácido acético, foi detectado por cromatografia gasosa. Nas amostras de efluentes dos demais experimentos não foram detectados ácidos, tanto nas análises em HPLC quanto em cromatógrafo de gás.

A presença de ácido acético no efluente indica que a rota de degradação do formaldeído pode não ter seguido somente a rota proposta por GONZALEZ-GIL et al. (1999), segundo a qual há a oxidação do formaldeído a ácido fórmico e sua redução a metanol. Essa discussão será retomada posteriormente no item 5.3.2.

\subsubsection{Considerações sobre o desempenho do RAHLF tratando formaldeído}

Os resultados encontrados para a degradação de formaldeído em reator anaeróbio horizontal de leito fixo indicam que esse sistema teve um comportamento estável para as concentrações estudadas, além de alcançar ótimos resultados, tanto na eficiência de remoção de DQO (média de $92 \%$ ), quanto de formaldeído (maior que 95\% para todos os experimentos, exceto o inicial com $26,2 \mathrm{mg} / \mathrm{L}$ de formaldeído afluente).

Os ensaios abióticos descritos na literatura por QU \& BHATTACHARYA (1997) relatam que, em testes em triplicata para a remoção de formaldeído por sorção, volatilização ou transformação química, apenas 10\% dos $30 \mathrm{mg} / \mathrm{l}$ de formaldeído foram removidos contra 26 mg/l removidos pela cultura acetoclástica em frascos, indicando que a biodegradação é o principal mecanismo para remoção de formaldeído. Esse resultado foi confirmado nos ensaios de OMIL et al. (1999), que obtiveram a faixa de 10-11 \% como fração de formaldeído removido abioticamente durante o primeiro dia de operação.

Embora não tenha sido feito ensaio específico quanto à adsorção de formaldeído pela espuma de poliuretano ou pela biomassa nesse trabalho, a degradação biológica certamente foi a principal forma de remoção de formaldeído, sendo confirmada pelas altas concentrações de metano no biogás e manutenção da concentração de biomassa no reator.

\subsection{Variação espacial de formaldeído e outros compostos ao longo do}

\section{RAHLF}

A avaliação da concentração de formaldeído ao longo do comprimento do reator objetivou obter informações essenciais para a otimização do processo de conversão, ou seja, 
através do perfil torna-se possível determinar qual é o tempo de detenção hidráulica realmente necessário para degradação do tóxico.

Como foi observada certa concentração de ácido acético no efluente do reator, conforme apresentado no item 5.2.5, decidiu-se também avaliar as concentrações de ácidos graxos voláteis, ácido fórmico e metanol com a finalidade de se esclarecer a rota de degradação do formaldeído.

As amostras foram tomadas no afluente $(\mathrm{L} / \mathrm{D}=0)$, efluente $(\mathrm{L} / \mathrm{D}=20)$ e em pontos intermediários (L/D = 4, 8, 12 e 16).

\subsubsection{Variação espacial da concentração de formaldeído}

As Figuras 5.12 a 5.20 e a Tabela 5.6 apresentam os resultados dos perfis de todas os experimentos. Para os experimentos com concentração de formaldeído afluente de 26,2 a 175,9 mg/L, a concentração de formaldeído em $\mathrm{L} / \mathrm{D}=8$ foi muito próxima à do efluente ( 3 mg/L). Para os experimentos com concentrações afluentes de formaldeído variando de 394,0 a 1416,8 mg/L isso ocorreu em $\mathrm{L} / \mathrm{D}=12$. Somente para o experimento de $1416,8 \mathrm{mg} / \mathrm{L}$ houve uma concentração considerável em L/D = 8 ( 126 mg/L).

Tabela 5.6: Variação espacial da concentração de formaldeído no RAHLF para concentrações afluentes de formaldeído variando de 23,0 a 1377,98 mg/L obtidas nas posições L/D iguais a 0 (entrada do reator), 4, 8, 12, 16 e 20 (efluente).

\begin{tabular}{cccccc}
\hline \multicolumn{6}{c}{ Concentração de Formaldeído (mg/L) em } \\
\hline $\mathbf{L} / \mathbf{D}=\mathbf{0}$ & $\mathbf{L} / \mathbf{D}=\mathbf{4}$ & $\mathbf{L} / \mathbf{D}=\mathbf{8}$ & $\mathbf{L} / \mathbf{D}=\mathbf{1 2}$ & $\mathbf{L} / \mathbf{D}=\mathbf{1 6}$ & $\mathbf{L} / \mathbf{D}=\mathbf{2 0}$ \\
\hline 23,0 & 2,8 & 2,7 & 2,5 & 2,3 & 2,5 \\
74,6 & 10,9 & 3,2 & 3,1 & 2,9 & 3,0 \\
161,5 & 6,8 & 3,0 & 3,2 & 3,3 & 3,0 \\
397,2 & 78,0 & 10,9 & 3,9 & 3,5 & 3,9 \\
585,0 & 95,5 & 7,4 & 4,3 & 3,3 & 3,8 \\
797,1 & 366,5 & 19,4 & 5,0 & 3,5 & 3,8 \\
998,6 & 386,2 & 12,7 & 3,6 & 3,6 & 3,5 \\
1124,3 & 745,0 & 9,6 & 3,0 & 3,2 & 3,7 \\
1378,0 & 1051,2 & 125,9 & 3,7 & 5,4 & 4,3 \\
\hline
\end{tabular}




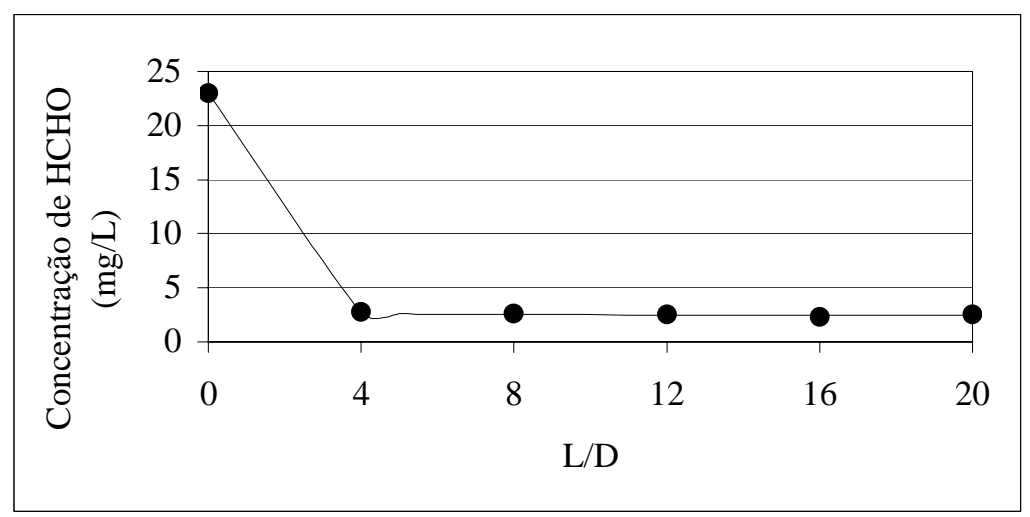

Figura 5.12: Variação espacial da concentração de formaldeído para o experimento com 26,2 mg/l de formaldeído afluente.

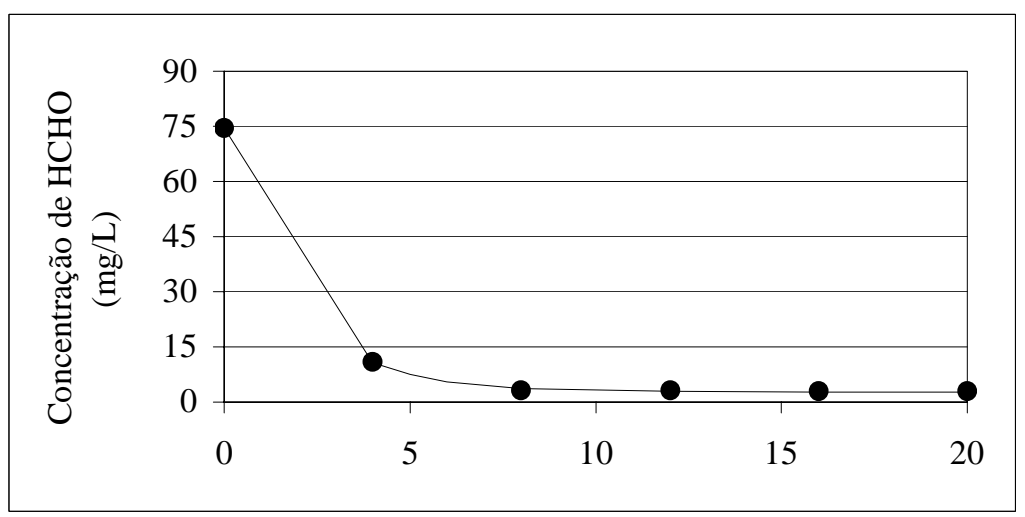

Figura 5.13: Variação espacial da concentração de formaldeído para o experimento com 85,3 mg/l de formaldeído afluente.

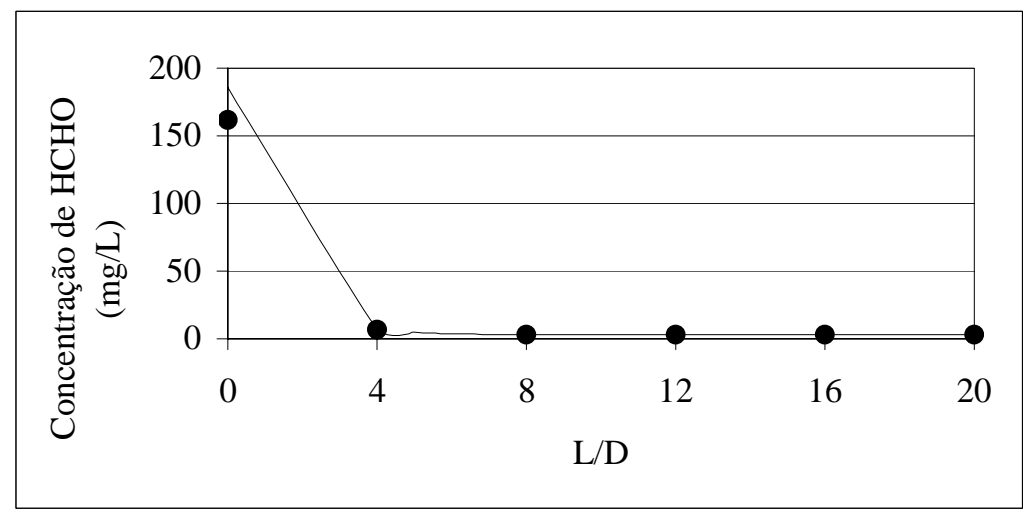

Figura 5.14: Variação espacial da concentração de formaldeído para o experimento com 175,9 mg/l de formaldeído afluente. 


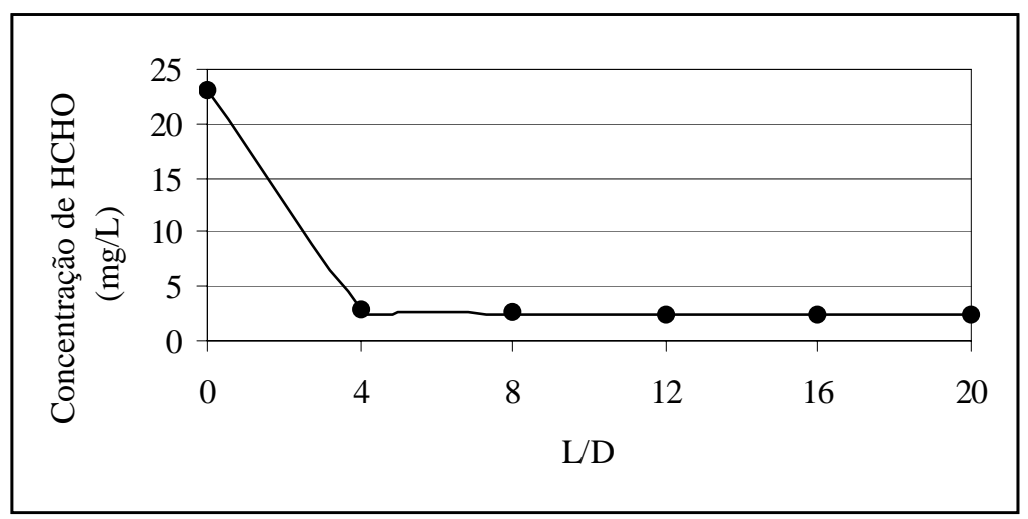

Figura 5.15: Variação espacial da concentração de formaldeído para o experimento com 394,0 mg/l de formaldeído afluente.

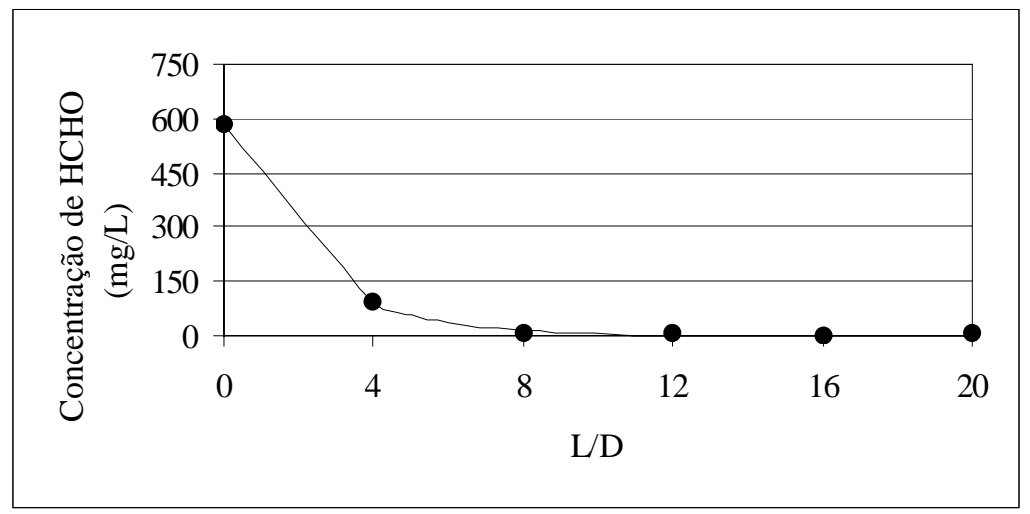

Figura 5.16: Variação espacial da concentração de formaldeído para o experimento com 597,7 mg/l de formaldeído afluente.

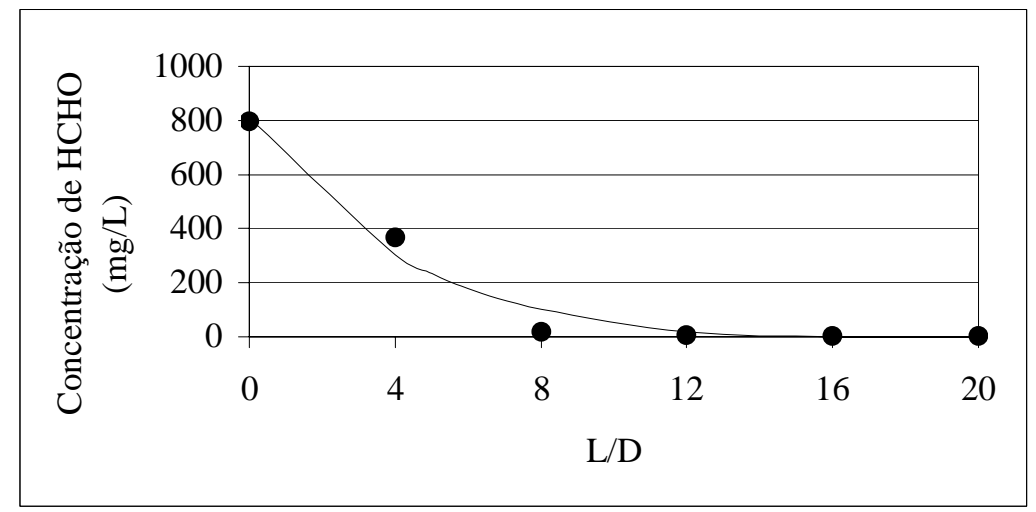

Figura 5.17: Variação espacial da concentração de formaldeído para o experimento com 808,0 mg/l de formaldeído afluente. 


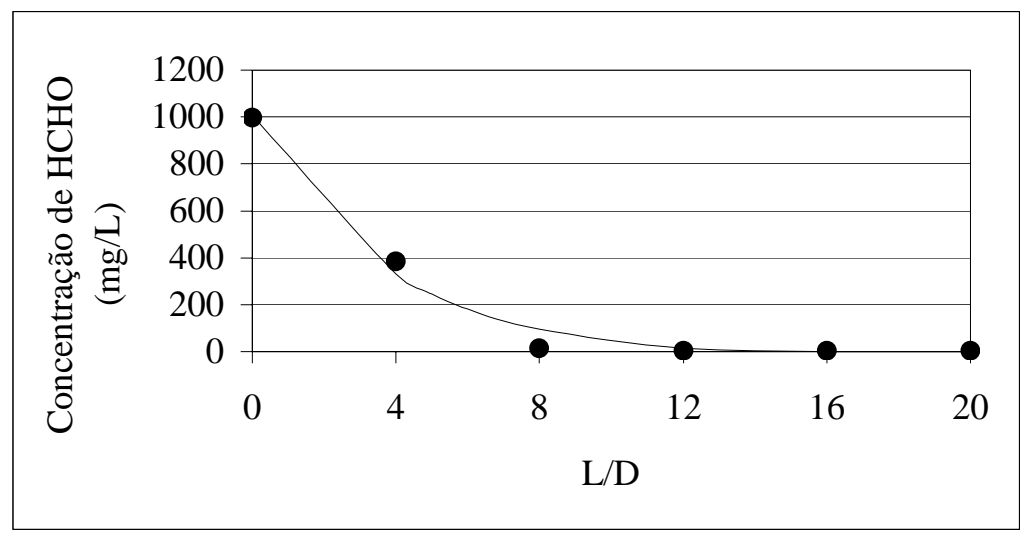

Figura 5.18: Variação espacial da concentração de formaldeído para o experimento com 989,2 mg/l de formaldeído afluente.

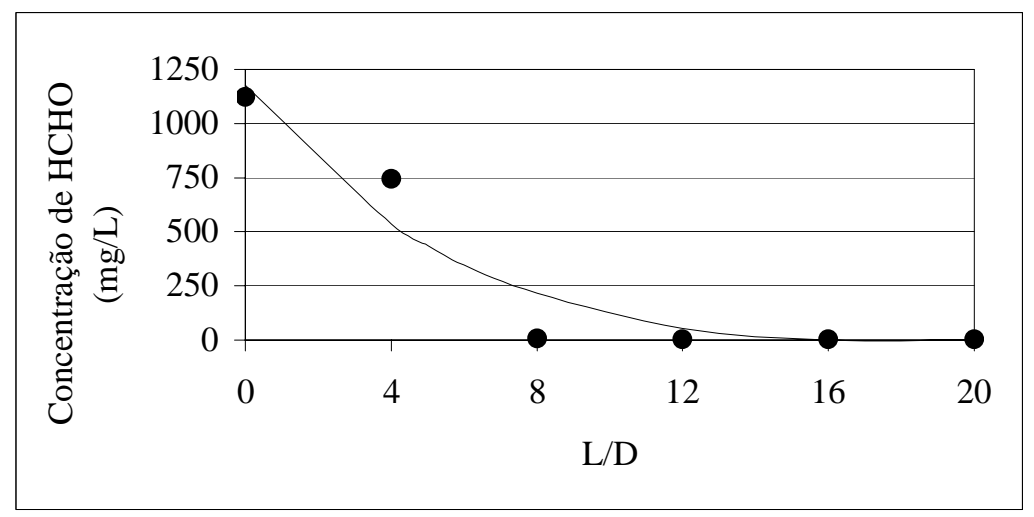

Figura 5.19: Variação espacial da concentração de formaldeído para o experimento com 1158,6 mg/l de formaldeído afluente.

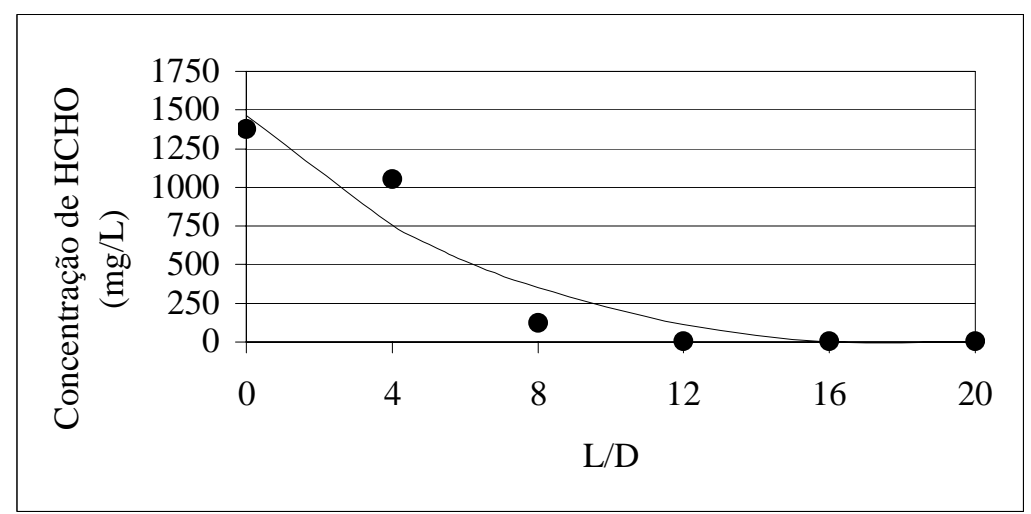

Figura 5.20: Variação espacial da concentração de formaldeído para o experimento com 1416,8 mg/l de formaldeído afluente. 
Dessa forma, para concentrações afluentes variando de 26,2 a 175,9 mg/L, a aplicação de tempo de detenção hidráulica de até 4,8 horas seria suficiente para se atingir a eficiência máxima de remoção. Para concentrações afluentes variando de 394,0 a 1416,8 mg HCHO/L, o tempo de detenção hidráulica aplicado poderia ser de, aproximadamente, 7 horas com segurança.

Comparando-se esses tempos de detenção hidráulica com os relatados na literatura para sistemas contínuos, verifica-se que o obtido no RAHLF para concentrações afluentes de 394,0 a 1416,8 mg HCHO/L (7 horas) é cerca de 50\% menor que o menor tempo para concentrações de 380 e $1000 \mathrm{mg}$ HCHO/L (14,88 horas), nos estudos de VIDAL et al. (1999) em UASB. A Tabela 5.4 apresenta os demais tempos de detenção hidráulica aplicados em outros estudos, variando de 14,88 horas a 14 dias para concentrações de 380 a 1110 mg/L de formaldeído. Para as concentrações afluentes de 26,2 a 175,9 mg HCHO/L (TDH=4,8 h) não há dados na literatura para comparações em sistemas contínuos. Esses pequenos tempos de detenção ótimos encontrados para o RAHLF são resultado de grande concentração de biomassa no reator, devido ao alto TRC alcançado, como já foi descrito anteriormente para esse tipo de reator.

De qualquer forma, tratamento eficiente poderia ser obtido com tempos de detenção hidráulica iguais ou menores que 4,8 horas ( $\mathrm{L} / \mathrm{D}=8$ ) para todas as concentrações, com eficiências de remoção variando de 88 \% a 99 \% e concentrações efluentes de 2,7 a 125,9 mg HCHO/L. Trata-se de tempo de detenção baixo em sistemas anaeróbios, mesmo para águas residuárias consideradas comuns, sem qualquer efeito tóxico.

Este resultado extremamente positivo pode estar associado à característica de escoamento no reator. O escoamento próximo ao pistonado poderia favorecer a degradação de tóxicos por permitir a adaptação de biomassa específica em trechos bem determinados do reator (ZAIAT et al., 1997). Neste tipo de escoamento nem todos os organismos estarão submetidos ao tóxico ou a subprodutos tóxicos do metabolismo, os quais são removidos continuamente do sistema ou removidos em regiões bem definidas por culturas adaptadas.

A imobilização da biomassa pode ser outro fator a contribuir para o resultado positivo na remoção do tóxico. A alta concentração celular favorecida pela imobilização e a conformação espacial dos organismos na matriz de imobilização podem ser fatores determinantes para o sucesso do tratamento. Além disso, a "proteção” oferecida pelo suporte aos microrganismos pode contribuir para os bons resultados obtidos. As resistências à transferência de massa na fase líquida e sólida podem constituir, em alguns casos, barreiras protetoras aos organismos imobilizados, impedindo que sejam submetidos a eventuais altas concentrações no meio líquido ou a variações bruscas nas cargas ou condições ambientais. 


\subsubsection{Variação espacial de outros compostos}

Como comentado anteriormente, a pequena quantidade de ácido acético encontrada no efluente do reator motivou a análise das concentrações de ácidos ao longo do reator. A presença de ácidos voláteis indica que a rota de degradação anaeróbia do formaldeído proposta por GONZALEZ-GIL et al. (1999) não estaria ocorrendo no sistema. Ademais, a presença de ácidos graxos de cadeia curta (2 ou três carbonos) indica a existência de síntese destes produtos por via biológica, o que parece difícil, ou indica a polimerização do formaldeído, possível na ausência de metanol.

Para a avaliação da variação espacial da concentração de ácidos voláteis foram analisadas as amostras dos perfis, por cromatografia gasosa, dos experimentos com concentração média afluente de formaldeído de 175,9 a 1158,6 mg/L. Foram coletadas amostras nos pontos correspondentes a L/D de 4 e 8 , por ser mais provável a obtenção de concentrações maiores de compostos intermediários nesses pontos. A Tabela 5.7 apresenta os resultados encontrados.

Tabela 5.7: Variação espacial da concentração de ácidos voláteis no RAHLF para concentrações afluentes de formaldeído variando de 175,9 a 1156,6 mg/L obtidas nas posições L/D iguais a 4 e 8 (N.D.=Não detectado).

\begin{tabular}{|c|c|c|c|c|c|c|c|}
\hline $\begin{array}{c}\text { Concentração } \\
\text { afluente de } \\
\mathrm{HCHO} / \mathrm{L} / \mathrm{D}\end{array}$ & $\begin{array}{l}\text { Acético } \\
\text { (mg/L) }\end{array}$ & $\begin{array}{c}\text { Propiônico } \\
\text { (mg/L) }\end{array}$ & $\begin{array}{c}\text { Isobutírico } \\
\text { (mg/L) }\end{array}$ & $\begin{array}{c}\text { Butírico } \\
\text { (mg/L) }\end{array}$ & $\begin{array}{c}\text { Isovalérico } \\
\text { (mg/L) }\end{array}$ & Valérico & Capróico \\
\hline $175,9 / 4$ & N.D. & & & \multirow{11}{*}{ 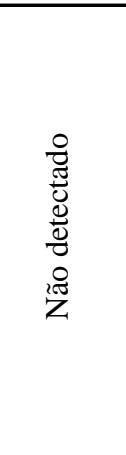 } & \multirow{3}{*}{ N.D. } & \multirow{14}{*}{ 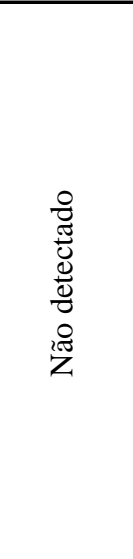 } & \multirow{14}{*}{ 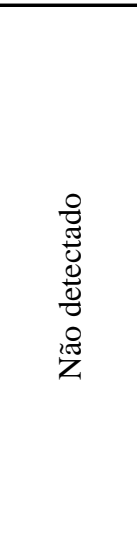 } \\
\hline $175,9 / 8$ & 18,3 & N.D. & ND & & & & \\
\hline $394,0 / 4$ & 82,4 & & N.D. & & & & \\
\hline $394,0 / 8$ & 34,2 & 1,2 & & & & & \\
\hline $597,7 / 4$ & 193,2 & 3,8 & 5,9 & & 2,0 & & \\
\hline $597,7 / 8$ & 63,9 & 1,4 & 1,0 & & N.D. & & \\
\hline $808,0 / 4$ & 123,5 & 3,2 & 3,1 & & 1,7 & & \\
\hline $808,0 / 8$ & 121,8 & 3,6 & 3,0 & & N.D. & & \\
\hline $989,2 / 4$ & 218,2 & 4,6 & 5,2 & & 1,5 & & \\
\hline $989,2 / 8$ & 179,6 & 7,1 & 7,0 & & 2,3 & & \\
\hline 1158,6 / 4 & 114,0 & 1,1 & 3,3 & & N.D. & & \\
\hline 1156,6 / 8 & 231,4 & 7,9 & 12,1 & 2,4 & 5,2 & & \\
\hline 1156,6 / 12 & $\begin{array}{l}3,0 \\
92\end{array}$ & N.D. & N.D. & N.D. & N.D. & & \\
\hline 1156,6 / 16 & 9,2 & & & & & & \\
\hline
\end{tabular}


As concentrações de ácido acético foram relativamente altas nos dois pontos amostrados, indicando que realmente houve uma rota diferente da relatada na literatura, segundo a qual o formaldeído seria convertido a metanol e a ácido fórmico, para posterior conversão a metano. As concentrações de ácidos propiônico e isobutírico encontradas foram sempre baixas nas duas posições analisadas. Mesmo assim, a presença destes ácidos indica uma rota diferente de conversão, com possível polimerização do formaldeído já que dificilmente se justificaria síntese de ácidos graxos com cinco carbonos por via biológica. Os outros ácidos praticamente não foram detectados nas amostras analisadas.

A variação da concentração de ácidos acético, propiônico e isobutírico no ponto L/D = 4 em função da concentração de formaldeído afluente (Figuras 5.21, 5.22 e 5.23) não seguiu o mesmo comportamento que o encontrado para L/D = 8 (Figuras 5.24, 5.25, 5.26). Em L/D igual a 4, os ácidos aumentam à medida que a concentração de formaldeído afluente é elevada para 597,7 mg/L. A partir daí, há tendência de estabilização das concentrações dos ácidos. Para a posição L/D igual a 8, entretanto, as concentrações dos ácidos acético, propiônico e isobutírico aumentam exponencialmente com o aumento da concentração de formaldeído afluente (Figuras 5.24 a 5.26).

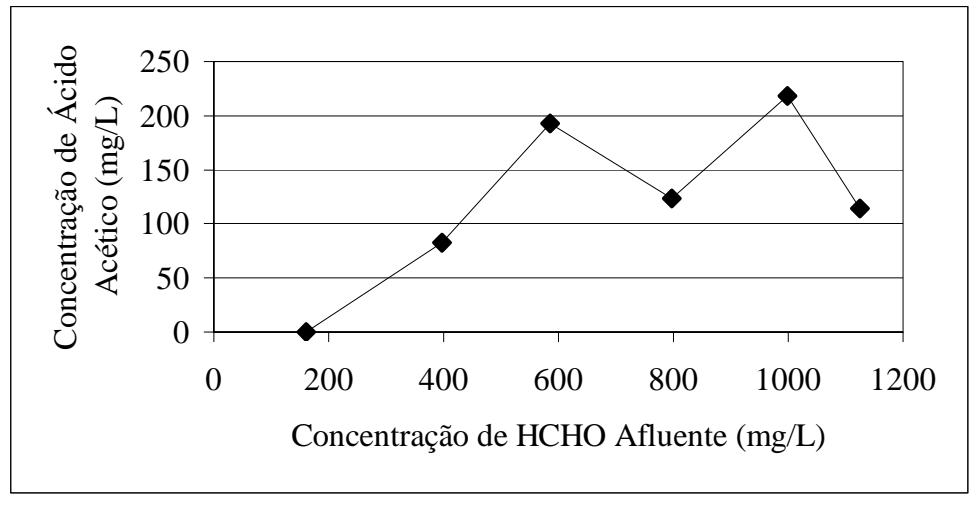

Figura 5.21: Variação da concentração de ácido acético em L/D=4 para experimentos com concentração afluente de formaldeído de 175,9 a 1158,6 mg/L. 


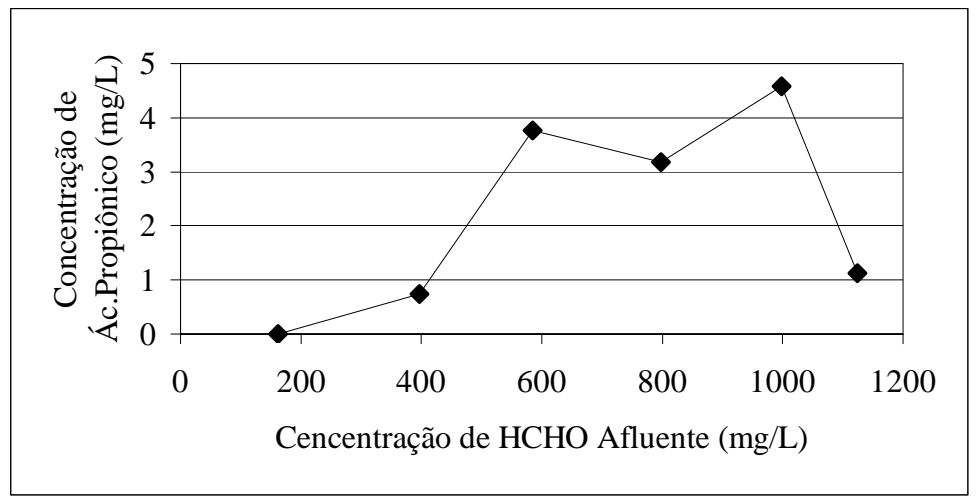

Figura 5.22: Variação da concentração de ácido propiônico em L/D=4 para experimentos com concentração afluente de formaldeído de 175,9 a 1158,6 mg/L.

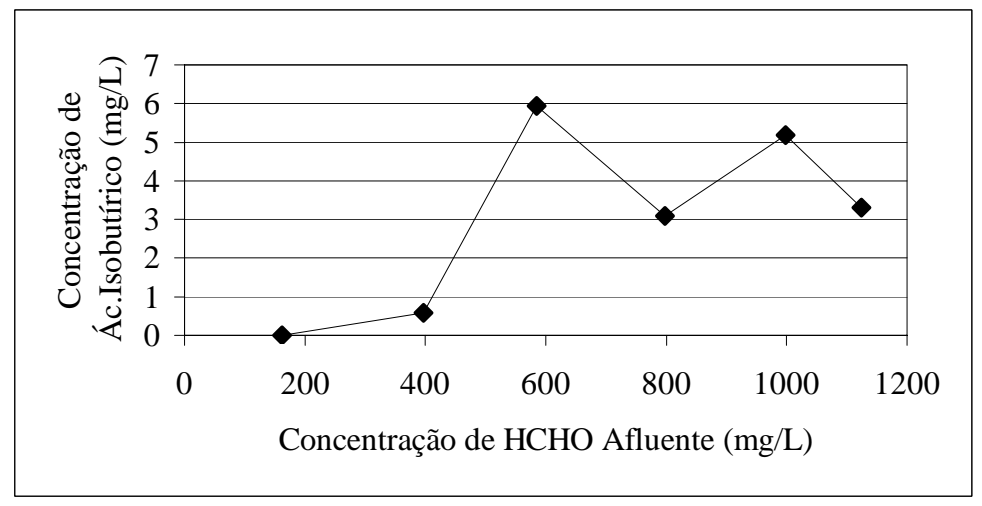

Figura 5.23: Variação da concentração de ácido isobutírico em $\mathrm{L} / \mathrm{D}=4$ para experimentos com concentração afluente de formaldeído de 175,9 a 1158,6 mg/L.

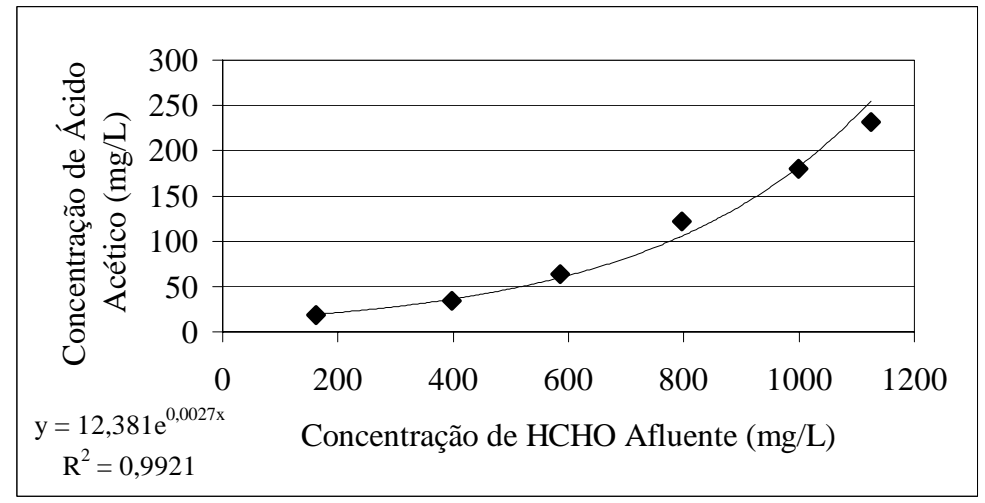

Figura 5.24: Variação da concentração de ácido acético em L/D=8 para experimentos com concentração afluente de formaldeído de 175,9 a 1158,6 mg/L. 


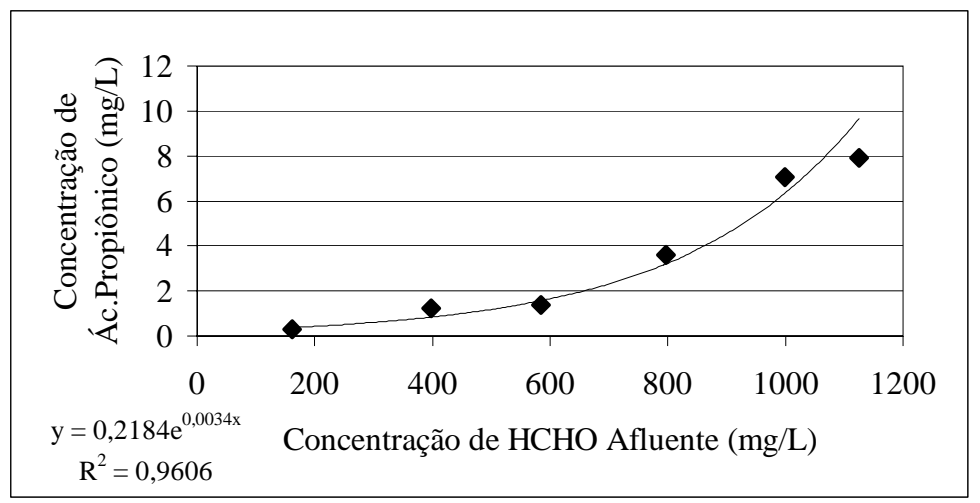

Figura 5.25: Variação da concentração de ácido propiônico em L/D=8 para experimentos com concentração afluente de formaldeído de 175,9 a 1158,6 mg/L.

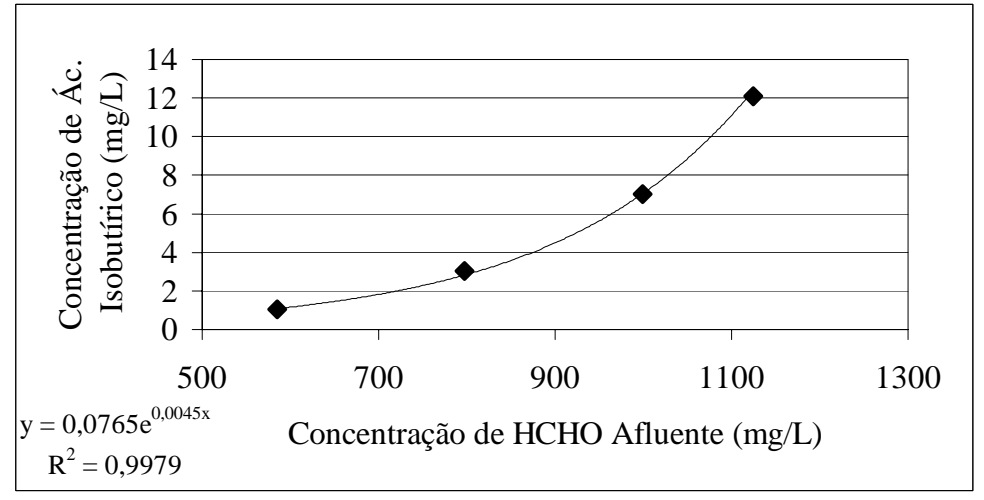

Figura 5.26: Variação da concentração de ácido isobutírico em $\mathrm{L} / \mathrm{D}=8$ para experimentos com concentração afluente de formaldeído de 597,7 a 1158,6 mg/L.

Para confirmação da rota de conversão do formaldeído, foi investigada a presença de ácido fórmico e metanol em algumas amostras de pontos intermediários do reator. Infelizmente, os métodos utilizados para detecção do metanol não foram satisfatórios, impedindo que se conclua sobre a presença ou ausência deste composto.

Para ensaios com concentrações iniciais de formaldeído de 1158,6 a 1416,8 mg/L foi detectada a presença do ácido fórmico, além do ácido lático (Tabela 5.8) utilizando-se cromatografia líquida de alta pressão (HPLC). Como se trata de outras amostras, há uma pequena divergência das concentrações em relação às encontradas por cromatografia gasosa.

Nos dois experimentos houve consumo do ácido fórmico de $\mathrm{L} / \mathrm{D}=4$ para $\mathrm{L} / \mathrm{D}=8$, ao contrário do ácido acético, que foi produzido entre esses dois pontos. Nas análises por cromatografia gasosa, também se confirmou a produção de ácido acético de $\mathrm{L} / \mathrm{D}=4$ para $\mathrm{L} / \mathrm{D}=8$, para o experimento com concentração inicial de formaldeído de 1158,6 mg/L. 
Tabela 5.8: Variação espacial da concentração de ácidos lático, fórmico e acético para os experimentos com 1158,6 e 1416,8 mg/L de HCHO afluente.

\begin{tabular}{cccc}
\hline $\begin{array}{c}\text { Concentração Afluente de } \\
\text { HCHO (mg/L) / L/D }\end{array}$ & Lático (mg/L) & Fórmico (mg/L) & Acético (mg/L) \\
\hline 1158,6 / 4 & - & 95,83 & 52,19 \\
1158,6 / 8 & 0,78 & 0,35 & 152,88 \\
1158,6 / 12 & - & 0,19 & - \\
1158,6 / 16 & - & - & - \\
1416,8 / 4 & 1,85 & 158,19 & 137,61 \\
1416,8 / 8 & 3,02 & 30,53 & 349,79 \\
\hline
\end{tabular}

A provável rota de degradação do formaldeído proposta por GONZALEZ-GIL et al. (1999), conforme expressão 5.1, é semelhante à “reação de Cannizzaro”, publicada em 1853, cujo nome homenageia o pesquisador que a descobriu, Stanislao Cannizzaro (1826-1910) (PAVLOV \& TÉRENTIEV, 1967; WALDEN, 1972). Nessa reação, uma molécula de formaldeído se oxida e a outra se reduz, sendo necessário um meio alcalino.

$2 \mathrm{HCHO}+\mathrm{H}_{2} \mathrm{O} \rightarrow \mathrm{CH}_{3} \mathrm{OH}+\mathrm{HCOOH}$

OMIL et al. (1999) relatam que a degradação anaeróbia do formaldeído envolve as reações descritas nas expressões 5.2 e 5.3, com a formação de metanol e hidrogênio. GONZALEZ-GIL et al. (1999) também citam a formação de hidrogênio como via intermediária da degradação de formaldeído, além do ácido fórmico e metanol.

$\mathrm{HCOH}+\mathrm{H}_{2} \mathrm{O} \rightarrow 2 \mathrm{H}_{2}+\mathrm{CO}_{2}$

$\mathrm{HCOH}+\mathrm{H}_{2} \rightarrow \mathrm{CH}_{3} \mathrm{OH}$

Neste trabalho, embora tenha sido encontrado ácido fórmico nas análises dos pontos $\mathrm{L} / \mathrm{D}=4$ e 8 (Tabela 5.8), em concentrações afluentes altas (1158,6 e 1416,8 mg/L de formaldeído), não foi possível a detecção do metanol. No entanto, a presença de ácidos com até 5 átomos de carbono significa que a degradação não obedeceu somente a essas rotas. A 
síntese de ácidos graxos com cinco carbonos por via biológica é uma hipótese pouco provável.

A presença de ácidos em outros trabalhos com co-substratos é explicável devido à presença inicial de compostos orgânicos com muitos átomos de carbono, como a glicose. Porém, nesse trabalho, o formaldeído foi utilizado como fonte única de carbono (com 10 \% de metanol como conservante no formol) e contém apenas um átomo de carbono por molécula.

Analisando-se uma das características químicas básicas do formaldeído, sua polimerização, é possível justificar a presença desses ácidos com até cinco carbonos, como o isovalérico $\left(\mathrm{C}_{5} \mathrm{H}_{10} \mathrm{O}_{2}\right)$.

MINGOIA (1967) cita o formol como sendo uma solução de 37\% de HCHO e seus polímeros, com quantidade variável de metanol. VOGEL (1971) adverte que o formaldeído se polimeriza rapidamente. Ao descrever a polimerização do formaldeído em presença de água, ALLINGER et al. (1978) citam a formação de um polioximetileno linear de fórmula $\mathrm{HO}-\left(\mathrm{CH}_{2} \mathrm{O}\right)_{\mathrm{n}}-\mathrm{CH}_{2} \mathrm{OH}$, com n de até 6000. Como já foi comentado, o metanol é adicionado à solução de formol para impedir que haja essa polimerização. MINGOIA (1967) ainda reporta que uma solução de formol mantida em longo repouso pode turvar-se devido à separação de polímeros.

O metanol presente no substrato do RAHLF, proveniente da solução de formol, pode ter sido degradado rapidamente, tornando o meio propício para a formação de polímeros do formaldeído. Essa hipótese é viável, uma vez que o metanol é um composto de fácil degradação pelos microorganismos e não é tóxico como o formaldeído. Embora não se tenha obtido bons resultados nas análises quanto à presença de metanol, também há a hipótese de que realmente havia uma quantidade muito pequena dessa substância e por isso não foi detectada. Nesse caso, poderia ter ocorrido a formação de polímeros que, pela degradação, transformaram-se em ácidos de 1 a 5 átomos de carbono.

O tamponamento exercido pela concentração de $2 \mathrm{~g} / \mathrm{L}$ de bicarbonato de sódio provavelmente conferiu estabilidade ao meio quanto à sua acidificação, permitindo que esses ácidos fossem consumidos. Apenas ácido acético, com concentrações abaixo de $21 \mathrm{mg} / \mathrm{L}$, foi detectado no efluente, nos experimentos com concentrações afluentes de 989,2 e 1158,6 mg/l de formaldeído.

A avaliação microbiológica da biomassa foi realizada como ferramenta para se tentar elucidar alguns aspectos da presença desses ácidos, principalmente o ácido acético, confirmando a provável formação de polímeros como justificativa. 


\subsection{Microbiologia}

Para se analisar a microbiologia do lodo através dos experimentos foi feita a microscopia ótica da biomassa aderida à espuma de poliuretano do inóculo (tratando fenol) e das concentrações afluentes médias de formaldeído de 175,9 a 1156,6 mg/L.

As amostras de espuma foram retiradas do RAHLF após o término do experimento para cada concentração, sempre da porção inicial do reator.

As Figuras 5.27 a 5.33 apresentam as observações morfológicas sob microscopia de contraste de fase para as amostras do inóculo e das concentrações já descritas de formaldeído afluente.

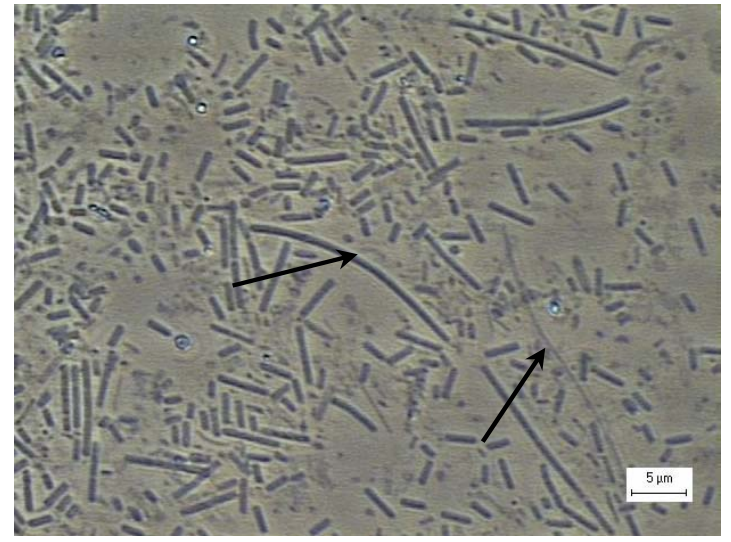

(a)

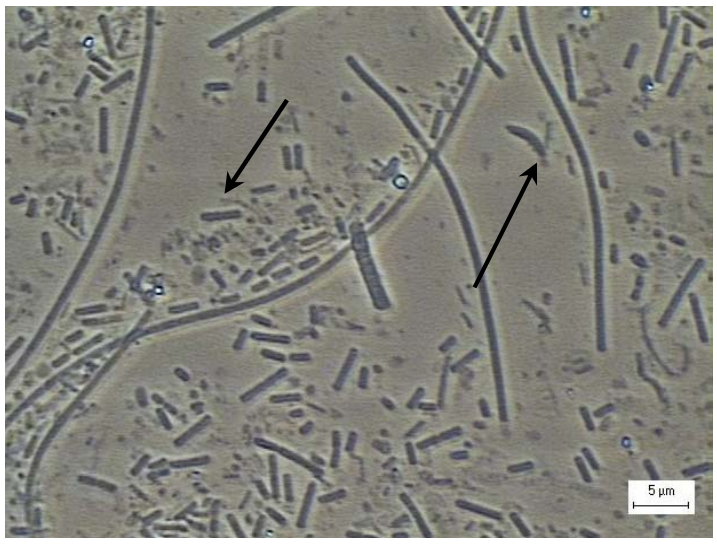

(b)

Figura 5.27: Observações morfológicas sob microscopia de contraste de fase referentes à amostra do inóculo: Methanosaeta sp.e filamento fino (a); bacilo com extremidade arredondada e bacilo curvo (b).

A Tabela 5.9 apresenta o resumo das morfologias dos microorganismos presentes na espuma de poliuretano do inóculo e das amostras ao longo dos experimentos com diferentes concentrações de formaldeído afluente. 


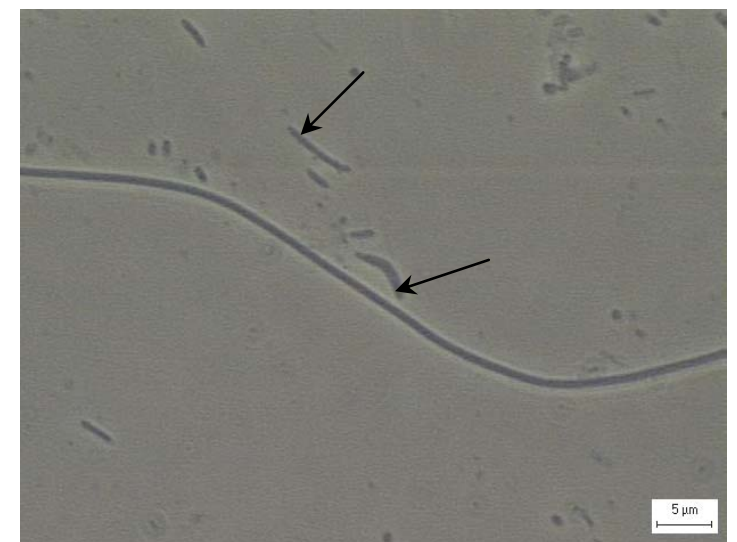

(a)

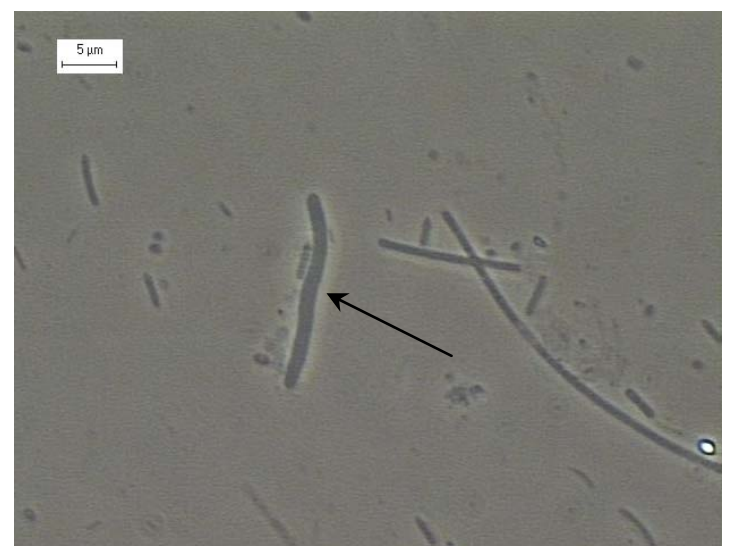

(c)

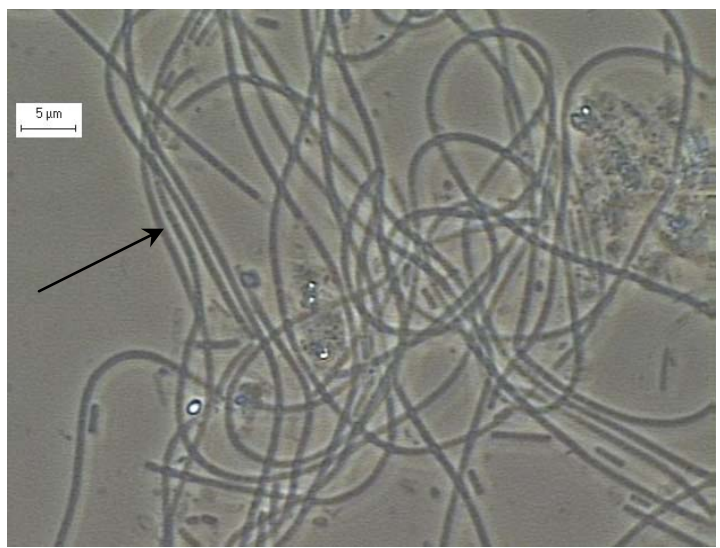

(b)

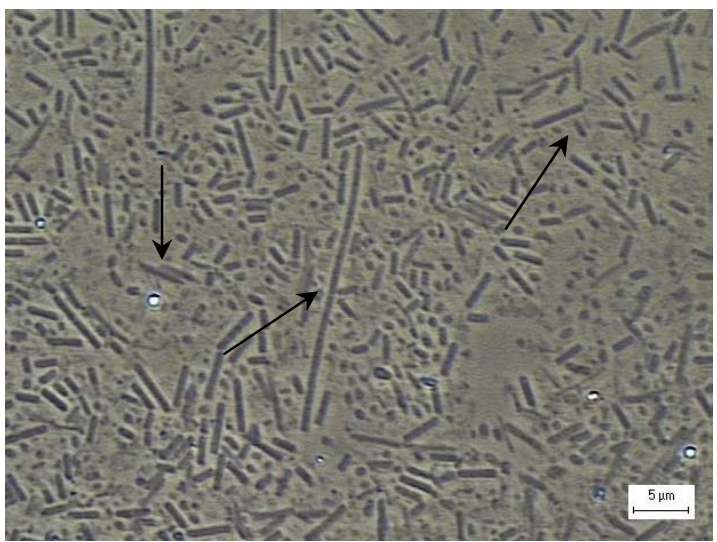

(d)

Figura 5.28: Observações morfológicas sob microscopia de contraste de fase referentes à amostra de 175,9 mg/L de formaldeído afluente médio: bacilo reto e bacilo curvo (a); Methanosaeta sp (b); filamento septado (c); bacilo com extremidades afiladas, Methanosaeta sp e bacilo com extremidades arredondadas (d). 


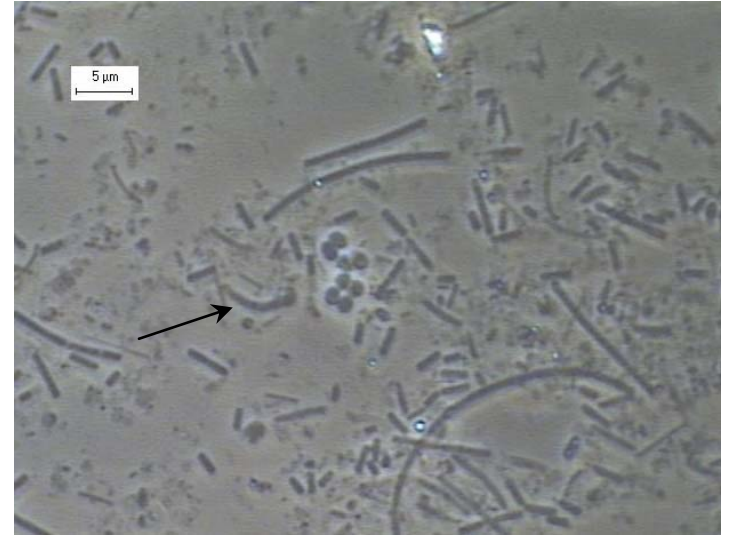

(a)

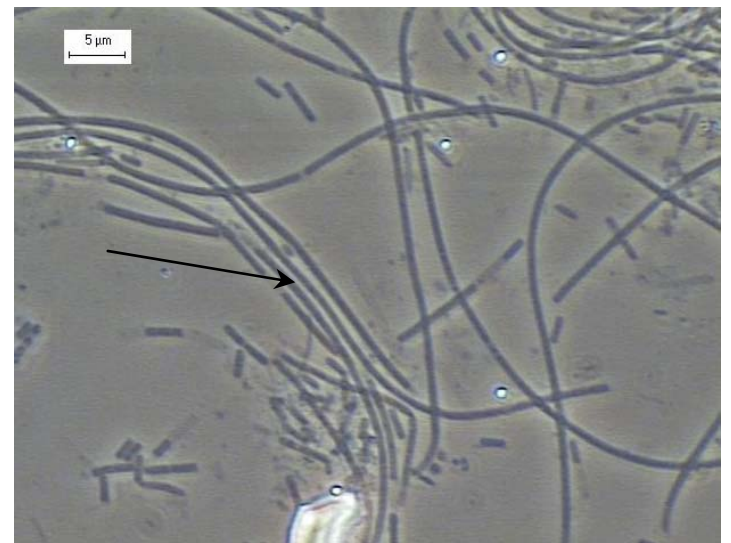

(c)

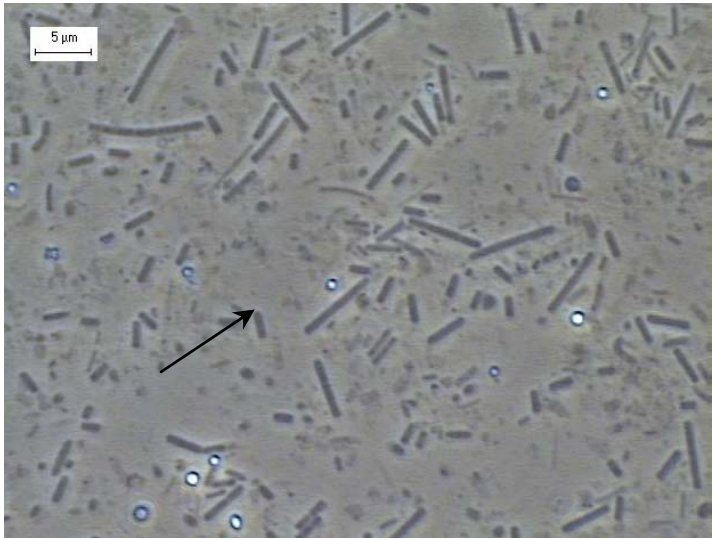

(b)

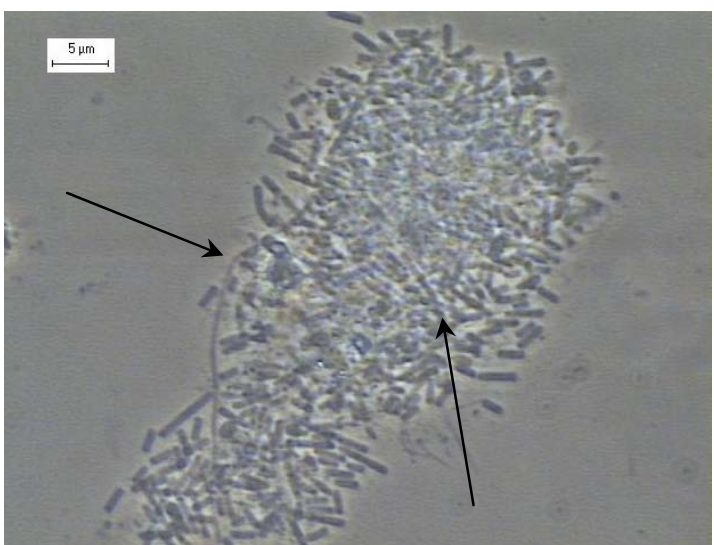

(d)

Figura 5.29: Observações morfológicas sob microscopia de contraste de fase referentes à amostra de 394,0 mg/L de formaldeído afluente médio: bacilo curvo e Methanosarcina sp. (a); bacilos com extremidades arredondadas e Methanosaeta sp (b); Methanosaeta sp (c); filamento fino e bacilos (d). 


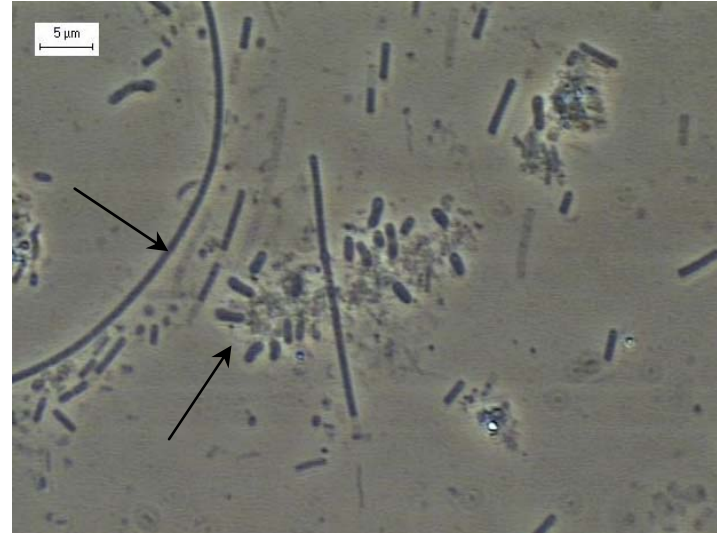

(a)

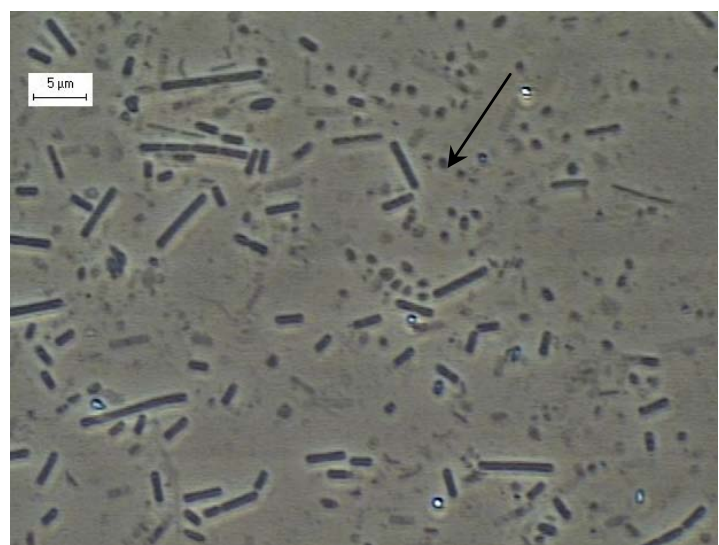

(c)

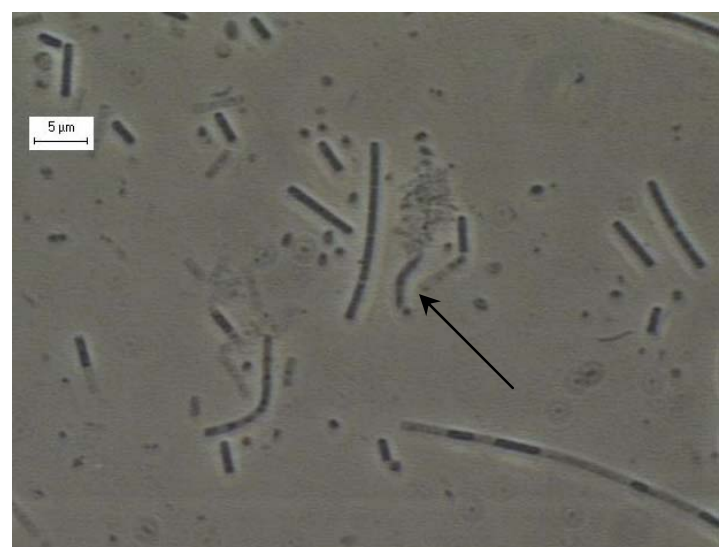

(e)

Figura 5.30: Observações morfológicas sob microscopia de contraste de fase referentes à amostra de 597,7 mg/L de formaldeído afluente médio: Methanosaeta sp. e bacilos com extremidades arredondadas (a); esporos de fungos (b); cocos (c); Methanosaeta sp. e bacilos com extremidades arredondadas (d); bacilo curvo (e); Methanosarcina sp. (f). 


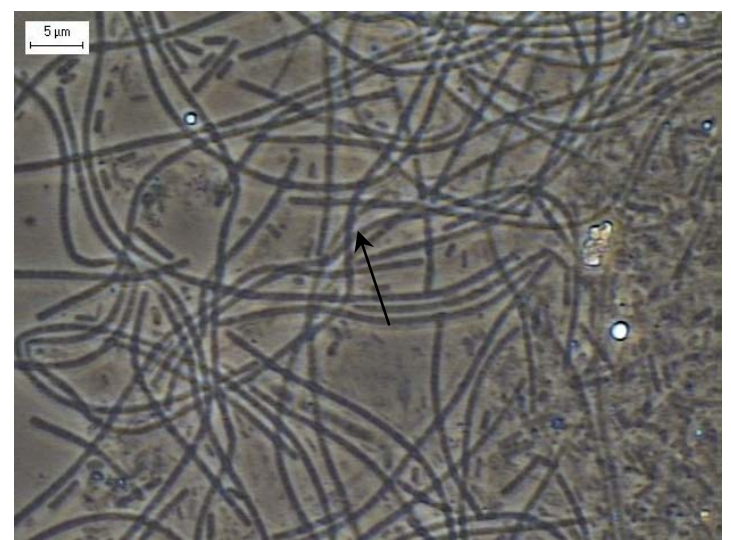

(a)

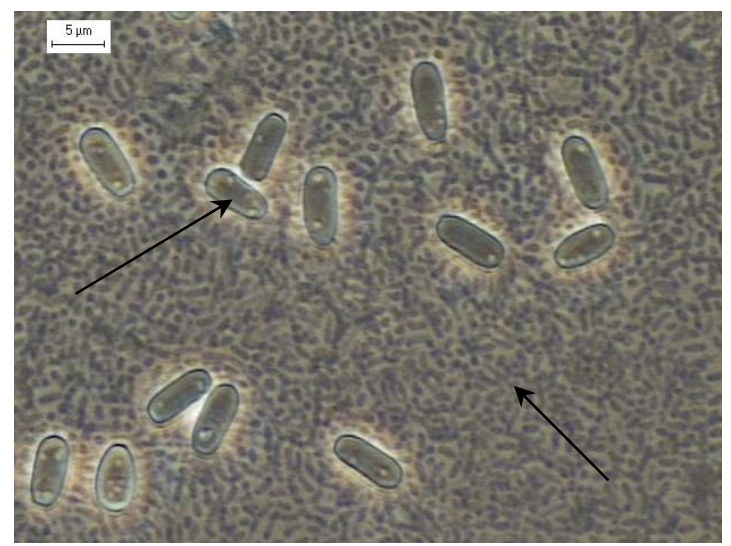

(c)

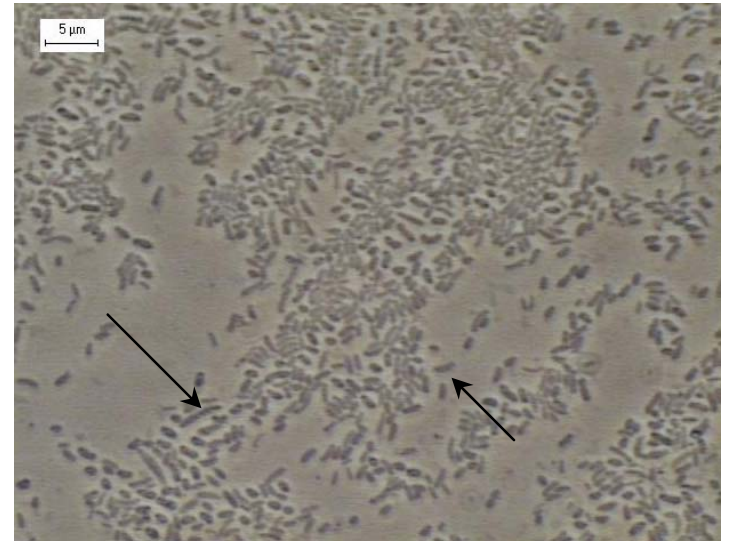

(e)

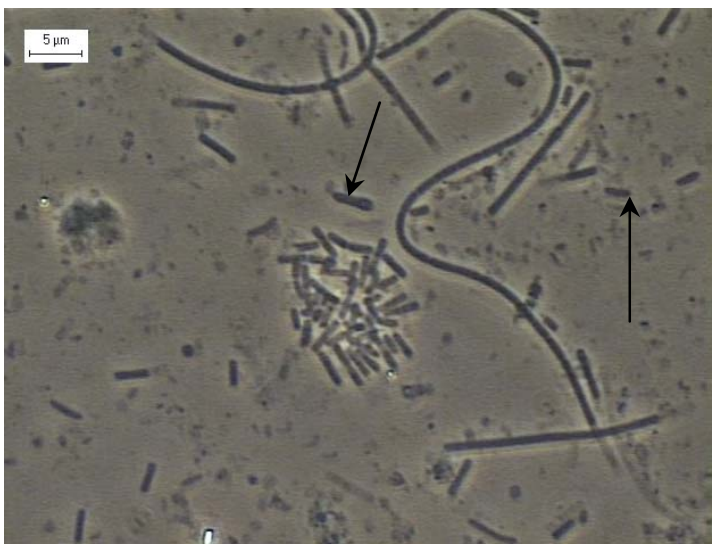

(b)

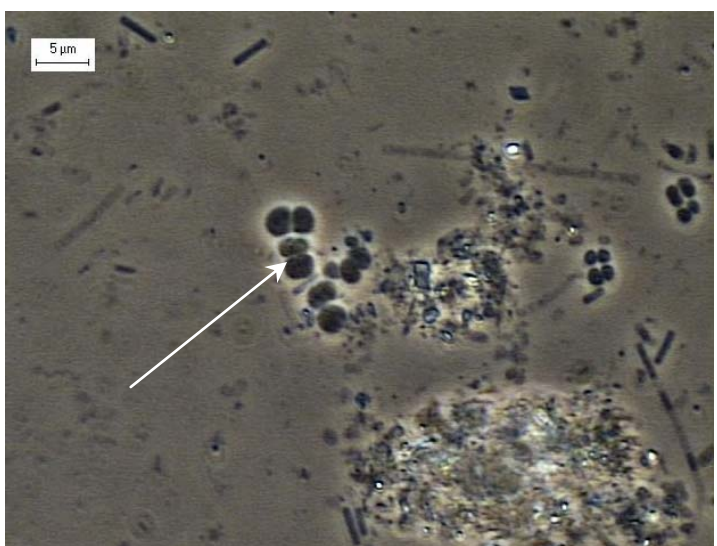

(d)

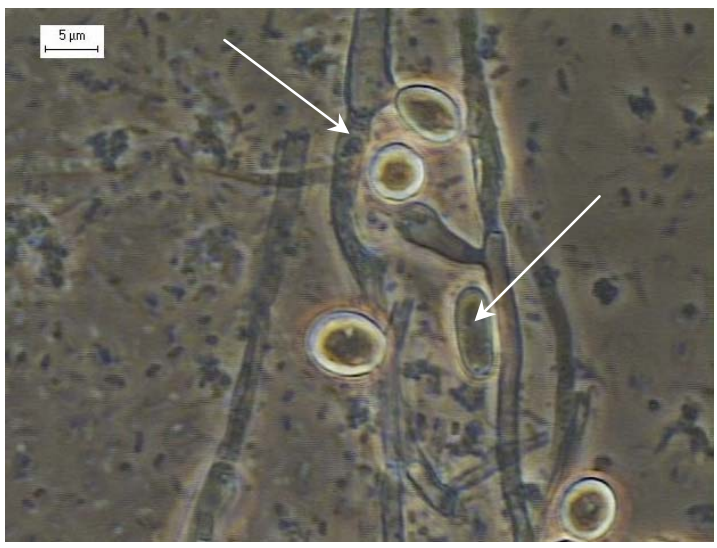

(f)

Figura 5.31: Observações morfológicas sob microscopia de contraste de fase referentes à amostra de 808,0 mg/L de formaldeído afluente médio: Methanosaeta sp.(a); bacilo esporulado e bacilo com extremidades arredondadas (b); esporos de fungos e bacilos (c); Methanosarcina sp.(d); bacilo com extremidade afilada e bacilo curvo 2 (e); fungos e esporos de fungos (f). 


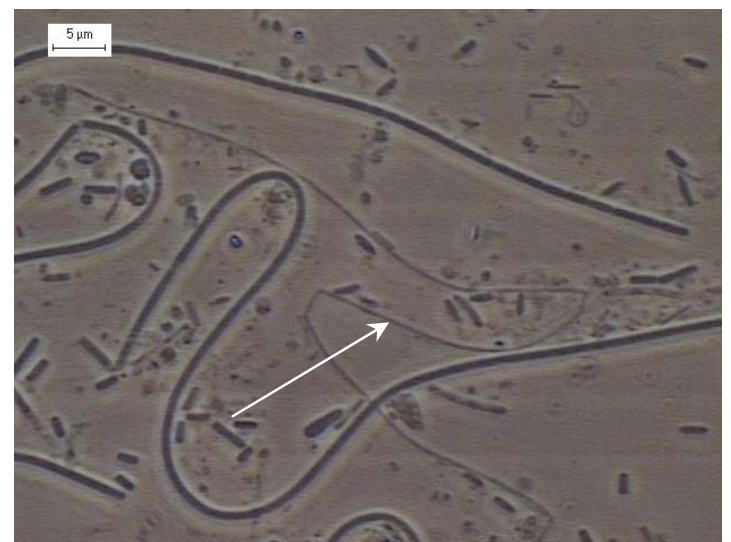

(a)

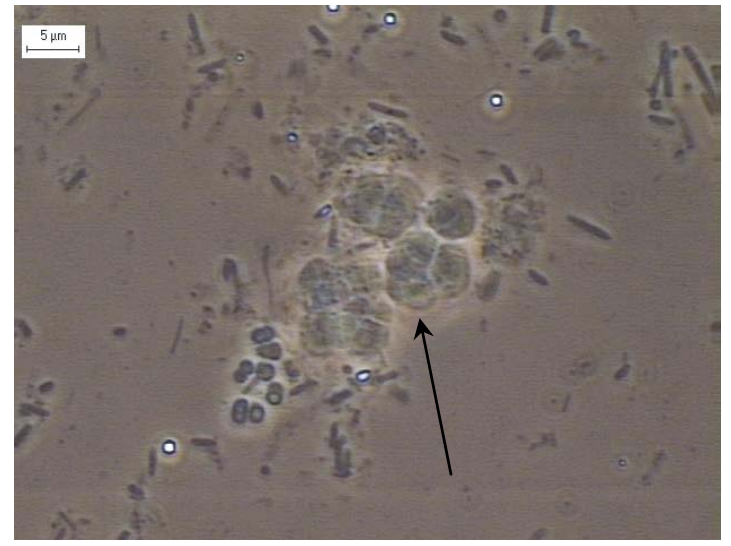

(c)

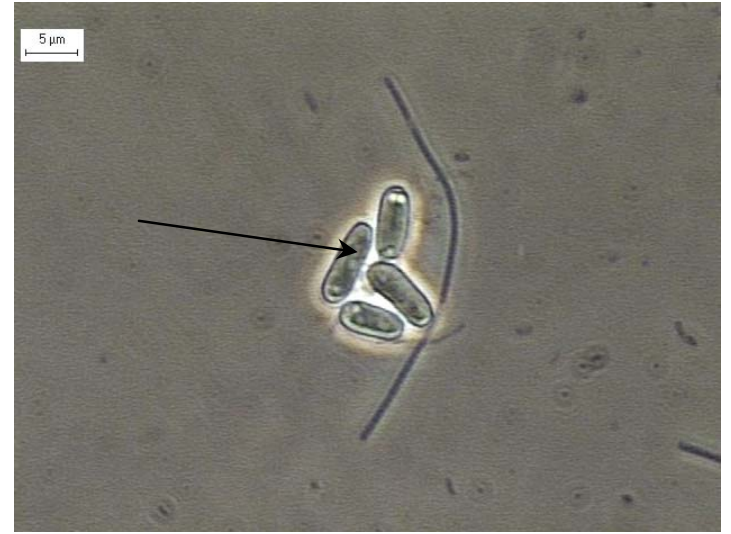

(e)

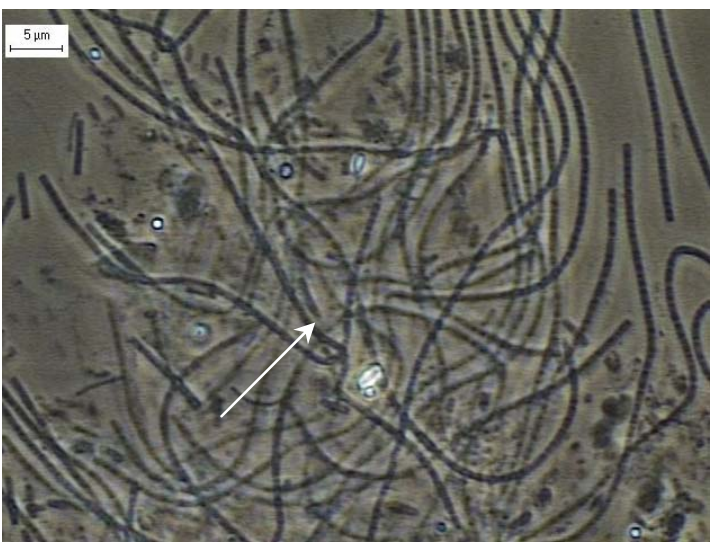

(b)

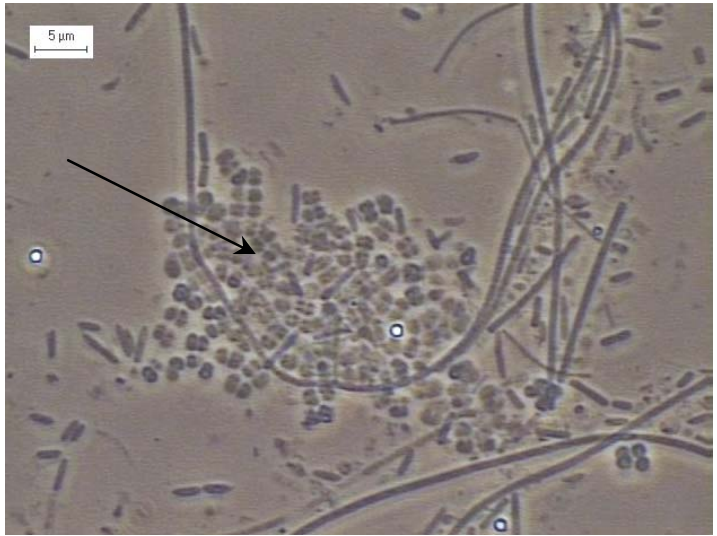

(d)

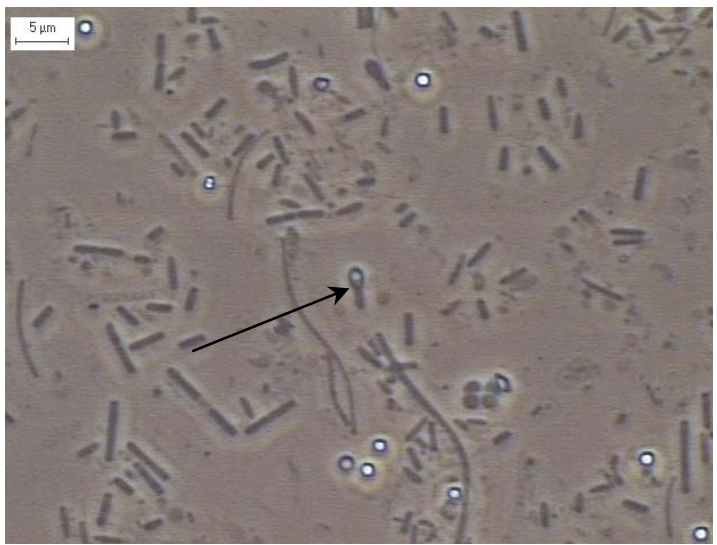

(f)

Figura 5.32: Observações morfológicas sob microscopia de contraste de fase referentes à amostra de 989,2 mg/L de formaldeído afluente médio:.filamento fino (a); Methanosaeta sp.

(b); Methanosarcina sp. (c); Methanosarcina sp.(d); esporos de fungos (e); bacilo esporulado (f). 


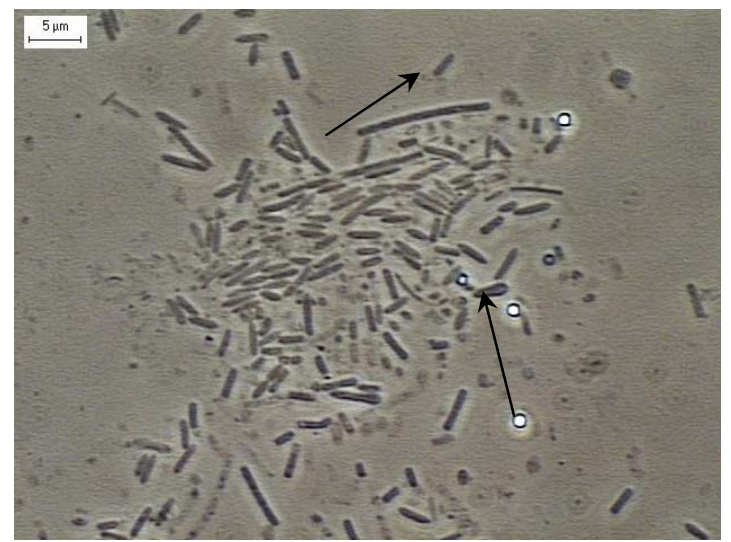

(a)

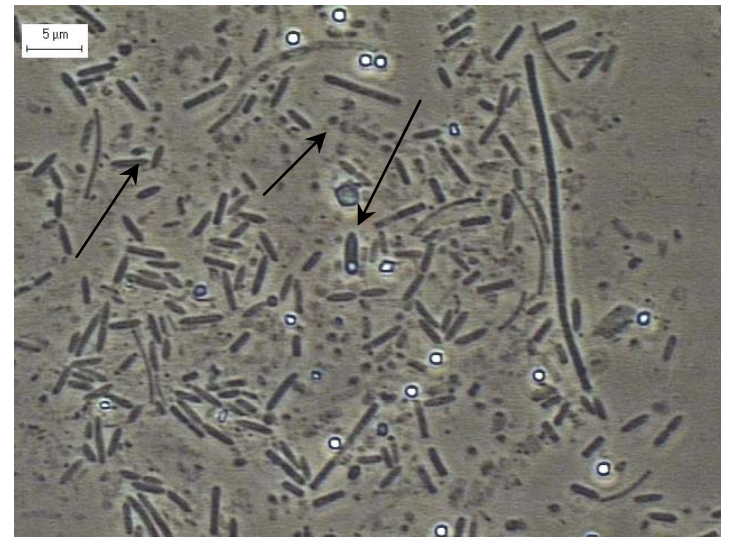

(c)

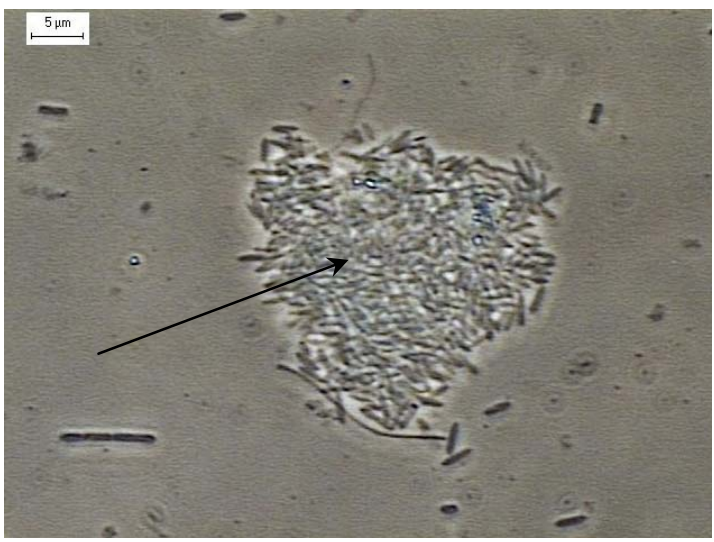

(b)

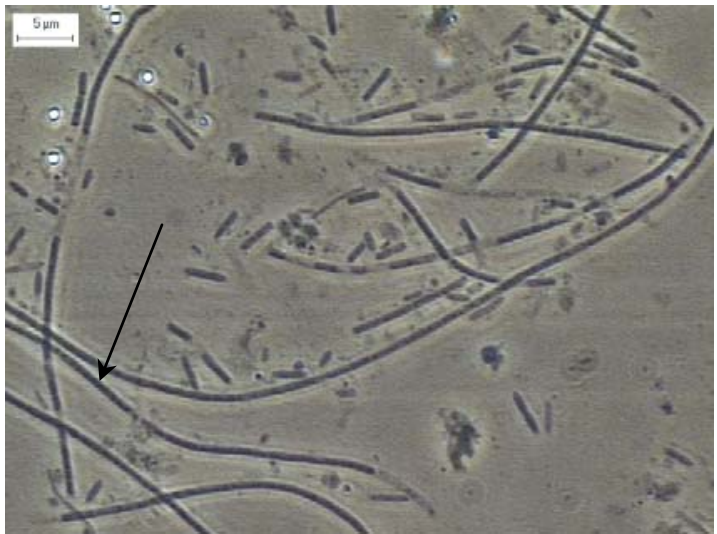

(d)

Figura 5.33: Observações morfológicas sob microscopia de contraste de fase referentes à amostra de 1158,6 mg/L de formaldeído afluente médio:.bacilo com extremidades afiladas e bacilo esporulado (a); bacilos (b); bacilo com extremidades afiladas, cocos e bacilo esporulado (c) e Methanosaeta sp.(d). 
Tabela 5.9: Morfologias dos microorganismos presentes na espuma de poliuretano do inóculo e ao longo dos experimentos com diferentes concentrações de formaldeído (++++ predominantes, +++ freqüentes, ++ pouco freqüentes, + raros, - não foram encontrados).

\begin{tabular}{|c|c|c|c|c|c|c|c|}
\hline \multirow{2}{*}{ Morfologias } & \multirow{2}{*}{ Inóculo } & \multicolumn{6}{|c|}{ Concentrações Afluentes de Formaldeído (mg/L) } \\
\hline & & 175,9 & 394,0 & 597,7 & 808,0 & 989,2 & 1156,6 \\
\hline $\begin{array}{l}\text { Bacilos com extremidades } \\
\text { afiladas }\end{array}$ & +++ & +++ & +++ & +++ & +++ & ++++ & ++++ \\
\hline $\begin{array}{l}\text { Bacilos com extremidades } \\
\text { aredondadas }\end{array}$ & +++ & +++ & +++ & +++ & ++++ & +++ & +++ \\
\hline Bacilos curvos 1 & ++ & + & + & + & + & + & + \\
\hline Bacilos curvos 2 & - & - & - & - & ++++ & ++++ & +++ \\
\hline Bacilos esporulados & - & - & + & + & + & ++ & +++ \\
\hline Bacilos fluorescentes & +++ & + & + & + & + & + & + \\
\hline Bacilos retos & +++ & +++ & +++ & +++ & +++ & +++ & +++ \\
\hline Cistos & - & - & - & ++ & - & - & - \\
\hline Cocos & ++ & + & + & ++ & ++ & ++ & ++ \\
\hline Esporos de fungos & - & - & - & + & +++ & + & - \\
\hline Filamentos finos & + & + & + & + & + & + & + \\
\hline Filamentos septados & + & + & - & - & - & - & - \\
\hline Fungos & - & - & - & - & ++ & ++ & - \\
\hline Methanosaeta sp. & ++++ & ++++ & ++++ & ++++ & ++++ & ++++ & ++++ \\
\hline Methanosarcina sp. & - & + & ++ & ++++ & ++++ & ++++ & ++++ \\
\hline
\end{tabular}

Como apresentado na Tabela 5.9, no inóculo proveniente do RAHLF tratando fenol (BOLAÑOS, 2001), observou-se o predomínio de organismos semelhantes à Methanosaeta, bacilos com extremidade afilada, bacilos com extremidade arredondada, bacilos retos e bacilos fluorescentes.

Após o período de 65 dias de alimentação do RAHLF com formaldeído, as morfologias mostraram tendências predominantes em função do aumento gradativo da concentração de formaldeído.

Entre as arqueas metanogênicas, predominaram para todas as concentrações estudadas, os organismos semelhantes à Methanosaeta. Os organismos semelhantes à Methanosarcina apareceram predominantemente após as concentrações médias afluentes de 394,0-597,7 mg/L de formaldeído. Em relação aos bacilos fluorescentes, foram visualizados raros organismos para todas as concentrações estudadas.

Nos estudos realizados no RAHLF por ZAIAT (1996) e BOLAÑOS (2001), tratando glicose e fenol, respectivamente, verificou-se o predomínio de organismos semelhantes à Methanosaeta nas espumas de poliuretano. 
GONZALEZ-GIL et al (1999) verificaram em reator EGSB tratando formaldeído, o predomínio de Methanosarcinas. O lodo utilizado pelos pesquisadores era adaptado a metanol e verificaram que parte do formaldeído era prontamente transformada em metanol. Provavelmente, a presença dessa substância no sistema favoreceu o crescimento de Methanosarcinas (BOONE \& MAH, 1984).

Nesse trabalho, provavelmente os organismos semelhantes à Methanosaeta prevaleceram sobre os semelhantes à Methanosarcina na utilização preferencial do acetato (ZEHNDER, 1984). Esse resultado foi constatado pelos valores obtidos na Tabela 5.7 para a concentração de 1156,6 mg/L de formaldeído afluente, onde houve a concentração de 231 $\mathrm{mg} / \mathrm{L}$ de ácido acético em $\mathrm{L} / \mathrm{D}=8$, e pouco mais de $9 \mathrm{mg} / \mathrm{L}$ em $\mathrm{L} / \mathrm{D}=16$, demonstrando o seu decaimento.

A presença de esporos de fungos e fungos foi observada no período em que o reator teve uma leve alteração no seu volume, durante a tentativa de medição da produção de gás, com um sistema de vasos comunicantes. Com essa alteração, a porção superior do reator recebeu menos substrato, tornando a biomassa mais seca. Nesse momento houve o aparecimento de fungos, conforme a Figura 5.34. A partir da retirada desse sistema, o reator voltou ao seu volume original e os fungos não foram mais observados.

Para as concentrações afluentes médias de 175,9 a 1156,6 mg/L de formaldeído, houve predomínio constante dos organismos semelhantes à Methanosaeta e à Methanosarcina. Os demais microrganismos anaeróbios (bacilos retos, bacilos curvos, bacilos com extremidades afiladas, bacilos com extremidades arredondadas, bacilos fluorescentes, cocos, filamentos finos e cistos) participaram da degradação do formaldeído, de seus polímeros e utilização dos outros ácidos orgânicos.

A hipótese de ter havido a polimerização do formaldeído no RAHLF e, por conseqüência, o aparecimento de ácidos orgânicos voláteis, pode explicar o aparecimento de organismos semelhantes à Methanosaeta. Nos estudos de GONZALEZ-GIL (1999) et al, a presença do metanol provavelmente impediu a polimerização, havendo predomínio de organismos semelhantes à Methanosarcina. 


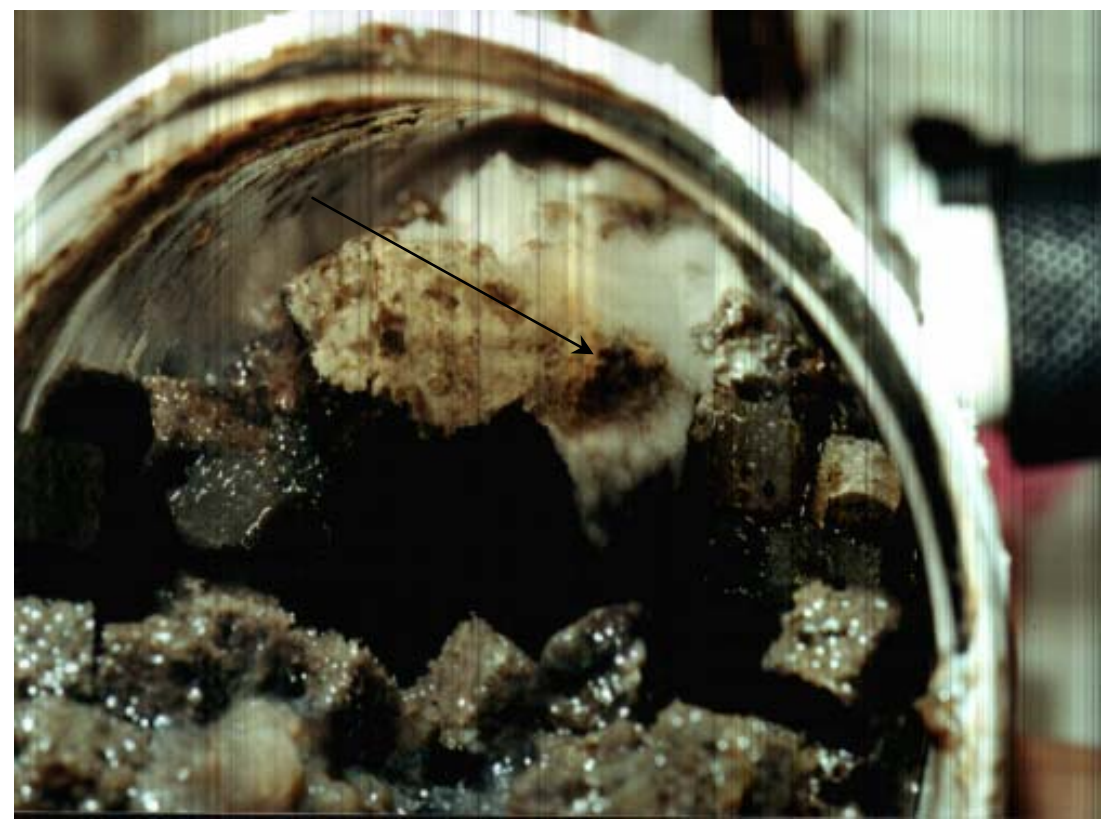

Figura 5.34: Fungo observado na porção inicial do RAHLF durante os experimentos com concentrações médias de 597,7 a 808,0 mg/L de formaldeído afluente.

\subsection{Estudo comparativo dos resultados do RAHLF com os da literatura}

A Tabela 5.10 apresenta um resumo dos trabalhos desenvolvidos com degradação anaeróbia de formaldeído com sistemas em batelada e a Tabela 5.11 resume os trabalhos em sistemas contínuos, incluindo os resultados alcançados pelo RAHLF.

A comparação entre os trabalhos deve ser feita com extremo cuidado, uma vez que nem todas as variáveis operacionais são equivalentes.

Nos sistemas em batelada, embora os reatores sejam semelhantes, a maioria em frascos de soro, foram utilizados inóculos, co-substratos, concentrações de biomassa e tempos de reação diferentes, conferindo resultados distintos e comparáveis com cautela. Além das diferentes procedências dos inóculos, em alguns trabalhos houve adaptação do lodo antes do experimento, podendo conferir resultados divergentes. 
Nos estudos com sistemas contínuos, também houve variação do tipo de reator. Foram empregados sistemas com mistura, sistemas sem agitação, com ou sem partículas de suporte. Houve uma grande variedade de inóculos, aclimatados ou não, co-substratos e TDH. A comparação dos resultados também deve ser feita com ressalvas.

No entanto, a comparação entre os dois conjuntos, batelada e contínuo, sugere que o segundo é mais adequado ao tratamento de formaldeído, pois foi possível a aplicação de concentrações mais altas de formaldeído com boas eficiências de degradação tanto de DQO, quanto de formaldeído. Deve ser ressaltado que a concentração de biomassa atingida pelos reatores contínuos foi muito superior às reportadas para os sistemas em batelada. Nos sistemas em batelada, essa concentração foi no máximo de 1,5 g SSV/L, enquanto que nos sistemas contínuos foram alcançadas concentrações de 23 g SSV/L (GONZALEZ-GIL et al., 1999) e 26,88 g SSV/L nesse trabalho. Isso provavelmente conferiu uma segurança maior aos sistemas quanto às propriedades tóxicas do formaldeído.

Como já foi mencionado por PARKIN \& SPEECE (1983), os sistemas com suporte alcançam um TRC maior que os reatores com crescimento suspenso, fato muito importante para o tratamento de tóxicos como o formaldeído. Nesse sentido, o RAHLF pode ser considerado muito adequado para esse tratamento, pois soma muitos fatores que o favorecem. 
Tabela 5.10: Resumo dos trabalhos com degradação anaeróbia de formaldeído com sistemas em batelada

\begin{tabular}{|c|c|c|c|c|c|c|c|c|c|}
\hline Sistema & Inóculo & Sustrato & $\begin{array}{l}\text { HCHO } \\
\text { testado } \\
\text { mg/L }\end{array}$ & $\begin{array}{l}\text { HCHO } \\
\text { efluente } \\
\mathrm{mg} / \mathrm{L}\end{array}$ & $\begin{array}{l}\text { Remoção de } \\
\text { HCHO (\%) }\end{array}$ & $\begin{array}{l}\text { Dose } \\
\text { limite } \\
\text { mg/L }\end{array}$ & $\begin{array}{l}\text { Tempe- } \\
\text { ratura } \\
\text { (oC) }\end{array}$ & Informações & Autor (es) \\
\hline $\begin{array}{l}\text { Frascos de soro em } \\
\text { batelada }\end{array}$ & Estação de tratamento municipal & HCHO e acetato & $100-500$ & & & $<100$ & 35 & & PARKIN et al. (1983) \\
\hline $\begin{array}{l}\text { Frascos de soro em } \\
\text { batelada }\end{array}$ & Lodo de digestor anaeróbio & НСHO & $10-100$ & & & $<100$ & 35 & & HICKEY et al. (1987) \\
\hline $\begin{array}{c}\text { Frascos de soro em } \\
\text { batelada }\end{array}$ & $\begin{array}{l}\text { Lodo de UASB de indústria } \\
\text { petroquímica }\end{array}$ & HCHO e sacarose & & & & 254 & & $1 \mathrm{~g} \mathrm{SSV/L}$ & $\begin{array}{l}\text { TODINI \& HOLSHOFF } \\
\text { POL (1992) }\end{array}$ \\
\hline & & HCHO e ácido acético & 10-96 & & & 62 & 35 & $220-360 \mathrm{mg}$ SSV/L & \\
\hline $\begin{array}{l}\text { Frascos de soro em } \\
\text { batelada }\end{array}$ & Cultura acetoclástica não aclimatada & НСHO & & & & & 35 & 1000 mg SSV/L & $\begin{array}{c}\text { QU \& } \\
\text { BHATTACHARYA } \\
\text { (1997) }\end{array}$ \\
\hline \multirow{3}{*}{$\begin{array}{l}\text { Frascos de soro em } \\
\text { batelada }\end{array}$} & \multirow{3}{*}{$\begin{array}{l}\text { Lodo ativado de estação tratando } \\
\text { formaldeído e lodo de digestor } \\
\text { anaeróbio de estação municipal }\end{array}$} & HCHO e glicose & $0-3000$ & 30 & 90 & 300 & 35 & & \multirow{3}{*}{$\begin{array}{l}\text { LU \& HEGEMANN } \\
\text { (1998) }\end{array}$} \\
\hline & & & & & & & & & \\
\hline & & Real: uréia-formaldeído & $100-600$ & 3 & 98 & 150 & 35 & & \\
\hline \multirow{2}{*}{$\begin{array}{l}\text { Frascos de soro em } \\
\text { batelada }\end{array}$} & \multirow{2}{*}{$\begin{array}{l}\text { Lodo metanogênico tratando efluente } \\
\text { de processamento de frutos do mar }\end{array}$} & $\begin{array}{l}\text { M1:AV com > proporção de } \\
\text { acetato e HCHO }\end{array}$ & $0-200$ & & & 125 & - & $1-1,5 \mathrm{~g} \mathrm{SSV} / \mathrm{L}$ & \multirow{2}{*}{ OMIL et al. (1999) } \\
\hline & & $\begin{array}{l}\text { M1:AV com > proporção de } \\
\text { butirato e propionato e } \\
\text { HCHO }\end{array}$ & & & & 100 & - & & \\
\hline $\begin{array}{l}\text { Reatores em batelada } \\
\text { com agitação } \\
\text { contínua }\end{array}$ & $\begin{array}{l}\text { Lodo de reator EGSB tratando } \\
\text { efluente de produção de HCHO } \\
\text { através de metanol }\end{array}$ & HCHO e metanol & $10-600$ & & & $600^{*}$ & & $\begin{array}{c}1,4 \mathrm{~g} \text { SSV/L / * *onversão } \\
\text { imediata do HCHO, porém } \\
\text { crescimento celular só após } 100 \\
\mathrm{~h}\end{array}$ & $\begin{array}{l}\text { GONZALEZ-GIL et al. } \\
\text { (1999) }\end{array}$ \\
\hline Reatores em batelada & $\begin{array}{l}\text { Lodo de EGSB tratanto efluente de } \\
\text { cervejaria }\end{array}$ & $\mathrm{HCHO}$ e acetato & $100-1000$ & & & $45^{*}$ & & $\begin{array}{l}\text { 1,5-3,0 } 0 \mathrm{~g} \mathrm{SSV} / \mathrm{L} / * \text { *Concentração } \\
\text { máxima para recuperação total }\end{array}$ & GONZALEZ-GIL (2000) \\
\hline
\end{tabular}


Tabela 5.11: Resumo dos trabalhos com degradação anaeróbia de formaldeído em sistemas contínuos.

\begin{tabular}{|c|c|c|c|c|c|c|c|c|c|}
\hline Sistema & Inóculo & Substrato & $\begin{array}{l}\text { HCHO testado } \\
\text { mg/L }\end{array}$ & $\begin{array}{l}\text { HCHO } \\
\text { efluente } \\
\text { mg/L }\end{array}$ & $\begin{array}{l}\text { Remoção de } \\
\text { HCHO (\%) }\end{array}$ & $\begin{array}{l}\text { Dose limite } \\
\text { mg/L }\end{array}$ & $\begin{array}{l}\text { Tempe- } \\
\text { ratura (oC) }\end{array}$ & Informações & Autor (es) \\
\hline Tanque com agitação contínua & Cultura acetoclástica & $\mathrm{HCHO}$ e acetato & $300 / 600 / 1800$ & & & & 35 & *Máximo tolerado & $\begin{array}{c}\text { PARKIN \& SPEECE } \\
\text { (1983) }\end{array}$ \\
\hline Filtro anaeróbio & & & & & & $400^{*}$ & 35 & & \\
\hline Filtros anaeróbios & Estação de tratamento municipal & HCHO e acetato & $100-400$ & & & $400^{*}$ & 35 & *Máximo tolerado & PARKIN et al. (1983) \\
\hline UASB & Não cita & $\begin{array}{l}\text { Efluente de indústria química } \\
\text { contendo } 900 \mathrm{mg} / \text { Lde formaldeído }\end{array}$ & $\begin{array}{l}\text { diluição não } \\
\text { definida }\end{array}$ & & $99^{*}$ & - & - & $\begin{array}{l}\text { *Não cita qual a } \\
\text { concentração afluente }\end{array}$ & $\begin{array}{l}\text { BORGHANS \& VAN } \\
\text { DRIEL (1988) }\end{array}$ \\
\hline $\begin{array}{l}\text { Tanque com agitação contínua } \\
\text { Tanque com agitação contínua } \\
\text { com partículas de suporte p/ } \\
\text { biomassa }\end{array}$ & Lodo de digestor anaeróbio & $\begin{array}{l}\text { Água residuária contendo acetato de } \\
\text { metila, ácido fórmico, formaldeído, } \\
\text { metanol e ácido acético }\end{array}$ & & & $\begin{array}{l}85-88 \\
95-98\end{array}$ & $\begin{array}{l}125^{*} \\
375^{*}\end{array}$ & 35 & *Máximo tolerado & $\begin{array}{l}\text { SHARMA et al. } \\
\text { (1994) }\end{array}$ \\
\hline Quimiostato & Cultura acetoclástica não aclimatada & HCHO e ácido acético & 100-1110 & $<1,0$ & 99,9 & $1110^{*}$ & 35 & $\begin{array}{l}\text { *444mg SSV/L e TRC/TDH } \\
14 \text { dias } \\
\end{array}$ & $\begin{array}{c}\text { QU \& } \\
\text { BHATTACHARYA } \\
\text { (1997) } \\
\end{array}$ \\
\hline EGSB escala real & Lodo granular de UASB & $\begin{array}{l}\text { Efluente de indústria de produção de } \\
\text { formaldeído a partir de metanol }\end{array}$ & $\begin{array}{l}\text { 333* (já } \\
\text { diluído) }\end{array}$ & $<20$ & $>93$ & - & - & $\begin{array}{l}\text { * concentrações do afluente } \\
\text { bruto: } 10 \mathrm{~g} / \mathrm{L} \mathrm{de} \\
\text { formaldeído e } 20 \mathrm{~g} / \mathrm{L} \text { de } \\
\text { metanol }\end{array}$ & $\begin{array}{l}\text { ZOUTBERG \& DE } \\
\text { BEEN (1997) }\end{array}$ \\
\hline EGSB de $4 \mathrm{~L}$ & $\begin{array}{l}\text { Lodo de reator EGSB tratando efluente } \\
\text { de produção de HCHO através de } \\
\text { metanol }\end{array}$ & $\mathrm{HCHO}$ e metanol & $\begin{array}{l}200 / 400 / 600^{*} \\
* * \\
200 / 400^{*} \\
* *\end{array}$ & & & $\begin{array}{l}\text { **Alta degra- } \\
\text { dação de } \\
\text { HCHO, } \\
\text { porém baixa } \\
\text { produção de } \\
\mathrm{CH}_{4}\end{array}$ & & $\begin{array}{l}23 \mathrm{~g} \mathrm{SSV} / \mathrm{L} \\
\text { *modo intermitente } \\
\\
23 \mathrm{~g} \mathrm{SSV} / \mathrm{L} \\
\text { *modo contínuo }\end{array}$ & $\begin{array}{l}\text { GONZALEZ-GIL et } \\
\text { al. (1999) }\end{array}$ \\
\hline \multirow[b]{2}{*}{ UASB de $0,1 \mathrm{~L}$} & \multirow[b]{2}{*}{$\begin{array}{l}\text { Lodo metanogênico tratando efluente } \\
\text { de processamento de frutos do mar }\end{array}$} & R1: HCHO e glicose & $50-2000$ & & 98 (de DQO) & $1000^{*}$ & 37 & $\begin{array}{l}\text { *Concentração com melhor } \\
\text { eficiência de remoção de } \\
\text { DQO }\end{array}$ & \multirow[b]{2}{*}{ VIDAL et al. (1999) } \\
\hline & & R2: Ureia-formaldeído e glicose & 95-950 & $<50$ & 95 (de DQO) & $380^{*}$ & 37 & $\begin{array}{c}\text { *Concentração com melhor } \\
\text { eficiência de remoção de } \\
\text { DQO }\end{array}$ & \\
\hline RAHLF de $2 \mathrm{~L}$ & Lodo metanogênico tratando fenol & HCHO e metanol & $30-1500$ & $<4,4$ & $\begin{array}{l}92 \text { (de DQO) } \\
99,7 \text { (de } \\
\text { HCHO) }\end{array}$ & $1500^{*}$ & 35 & $\begin{array}{l}\text { *Máxima concentração } \\
\text { estudada. Não houve } \\
\text { inibiçãao }\end{array}$ & Este trabalho \\
\hline
\end{tabular}




\subsection{Estimativa dos Parâmetros Cinéticos de Degradação do Formaldeído}

A estimativa dos parâmetros cinéticos foi feita considerando-se o escoamento do reator como tubular ideal, resultando na expressão de balanço:

$\mathrm{R}_{\mathrm{obs}}=\frac{-\varepsilon \cdot \mathrm{V}_{\mathrm{s}}}{\mathrm{D}} \cdot \frac{\mathrm{dC}_{\mathrm{F}}}{\mathrm{d}(\mathrm{L} / \mathrm{D})}$

Nessa expressão, $\mathrm{R}_{\mathrm{obs}}$ é a velocidade global de reação, $\varepsilon$ é a porosidade do leito, $\mathrm{V}_{\mathrm{s}}$ é a velocidade superficial de líquido, $\mathrm{D}$ é o diâmetro do RAHLF e $\mathrm{C}_{\mathrm{F}}$ é a concentração de formaldeído na fase líquida numa determinada posição longitudinal L/D.

A velocidade superficial do líquido no leito de espuma de poliuretano $\left(\mathrm{v}_{\mathrm{s}}\right)$ foi mantida constante durante toda a operação em $8,36 \mathrm{~cm} / \mathrm{h}$, calculada como:

$\mathrm{v}_{\mathrm{s}}=\frac{\mathrm{Q}}{\varepsilon \cdot \mathrm{A}}$

A área seccional do reator tem valor de $19,95 \mathrm{~cm}^{2}$ e a porosidade do leito é estimada em 0,4 através de trabalhos anteriores com leito de espuma (ZAIAT et al., 2000).

Dessa forma, a expressão (5.4) pode ser escrita como:

$R_{\text {obs }}=-0,663 \cdot \frac{\mathrm{dC}_{\mathrm{F}}}{\mathrm{d}(\mathrm{L} / \mathrm{D})}$

O primeiro passo para estimativa da velocidade global de reação é a obtenção de valores da derivada da concentração de formaldeído em função da posição longitudinal do reator. Como apresentado no capítulo Material e Métodos, obteve-se um valor de $\mathrm{R}_{\mathrm{obs}}$ para cada concentração ensaiada. Este valor foi estimado no ponto inicial do reator ( $\mathrm{L} / \mathrm{D}=0$ ) através do ajuste de função ao perfil obtido (Figuras 5.12 a 5.20) e obtenção da derivada no ponto L/D igual a zero. Este é o "método das velocidades iniciais”.

As velocidades específicas de utilização de substrato observadas ( $\mathrm{r}_{\mathrm{obs}}$ ) foram posteriormente calculadas pela relação:

$\mathrm{robs}_{\mathrm{s}}=\frac{\mathrm{R}_{\mathrm{obs}}}{\mathrm{X}}$ 
Nessa expressão, X é a concentração celular em relação ao volume líquido do sistema. No caso estudado, o valor de $\mathrm{X}$ foi considerado constante ao longo de todo experimento, conforme discussão anterior. Baseado no volume líquido do sistema, a concentração média de biomassa foi de 67.200 mg SSV/L.

O procedimento de ajuste e derivação foi realizado com auxílio do software Microcal Origin $5.0^{\circledR}$ e as velocidades iniciais de reação obtidas em função da concentração de formaldeído são apresentadas na Tabela 5.12.

Tabela 5.12: Velocidades de reação em função da concentração de formaldeído aplicada ao reator anaeróbio horizontal.

\begin{tabular}{cccc}
\hline $\begin{array}{c}\mathrm{C}_{\mathrm{F}} \\
(\mathrm{mg} \mathrm{HCHO} / \mathrm{L})\end{array}$ & $\begin{array}{c}\mathrm{dC}_{\mathrm{F}} / \mathrm{d}(\mathrm{L} / \mathrm{D}) \\
(\mathrm{mg} \mathrm{HCHO} / \mathrm{L})\end{array}$ & $\begin{array}{c}\mathrm{R}_{\mathrm{obs}} \\
(\mathrm{mg} \mathrm{HCHO} / \mathrm{L} . \mathrm{h})\end{array}$ & $\begin{array}{c}\mathrm{r}_{\mathrm{obs}} \mathrm{x} 10^{3} \\
(\mathrm{mg} \mathrm{HCHO} / \mathrm{mg} \\
\text { SSV.h) }\end{array}$ \\
\hline 23 & 18,3 & 12,3 & 0,18 \\
75 & 36,0 & 23,9 & 0,36 \\
186 & 144,8 & 96,1 & 1,43 \\
397 & 154,0 & 102.2 & 1,52 \\
585 & 249,7 & 165,6 & 2,46 \\
797 & 186,6 & 123,8 & 1,84 \\
999 & 262,7 & 174,3 & 2,59 \\
1124 & 214,6 & 142,4 & 2,12 \\
1378 & 224,5 & 148,9 & 2,22 \\
\hline
\end{tabular}

* Obtida no ponto $\mathrm{L} / \mathrm{D}=0$

Os dados de $r_{\text {obs }}$ foram correlacionados com os dados de concentração de formaldeído para obtenção do modelo cinético que melhor representasse tal comportamento. O modelo cinético clássico de Monod (BAILEY \& OLLIS, 1986) foi o que melhor representou os dados experimentais como:

$$
\text { robs }=r_{\max }^{\text {app }} \frac{C_{F}}{K_{S}^{a p p}+C_{F}}
$$


Nessa expressão, $\mathrm{r}_{\mathrm{obs}}$ é a velocidade específica de utilização de substrato observada, $\mathrm{C}_{\mathrm{F}}$ é a concentração de formaldeído na fase líquida, $\mathrm{r}_{\max }^{\text {app }}$ é a velocidade específica máxima de consumo de substrato (aparente) e $\mathrm{K}_{\mathrm{S}}^{\mathrm{app}}$ é a constante de saturação de substrato (aparente).

Os parâmetros cinéticos $\mathrm{r}_{\max }^{\text {app }}$ e $\mathrm{K}_{\mathrm{S}}^{\mathrm{app}}$ são aparentes, pois englobam a influência dos fenômenos de transferência de massa, isto é, não são parâmetros que expressam diretamente o consumo do substrato. Dessa forma, a expressão (5.8) é adequada para representação cinética do sistema, nas condições operacionais específicas a que estava submetido o reator.

O ajuste da expressão cinética de Monod aos pontos experimentais, com coeficiente de correlação de 0,88542, é apresentado na Figura 5.34. O ajuste foi feito utilizando-se método de regressão não linear de Levenberg-Marquardt (Microcal Origin 5.0 ${ }^{\circledR}$ ).

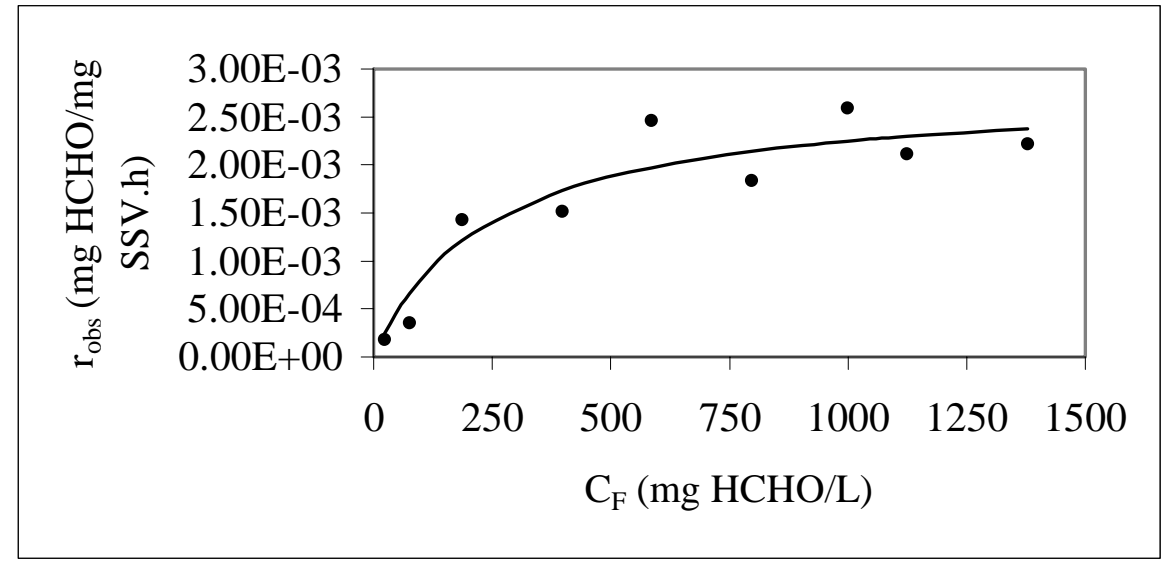

Figura 5.35: Ajuste de expressão cinética de Monod (-) aos pontos experimentais (•).

Os parâmetros cinéticos aparentes da expressão cinética de Monod, obtidos a $35^{\circ} \mathrm{C}$, para degradação anaeróbia de formaldeído no reator horizontal de leito fixo foram:

$\mathrm{r}_{\max }^{\text {app }}=2,79 \times 10^{-3}\left( \pm 3,7 \times 10^{-4}\right) \mathrm{mg} \mathrm{HCHO} / \mathrm{mg} \mathrm{SSV} . \mathrm{h}$

$\mathrm{K}_{\mathrm{S}}^{\mathrm{app}}=242,8( \pm 114,1) \mathrm{mg} \mathrm{HCHO} / \mathrm{L}$

Infelizmente, há poucos dados na literatura para comparação desses valores. QU \& BHATTACHARYA (1997) reportaram que a degradação do formaldeído seguiu o modelo de Monod, em seus experimentos com concentração inicial menor que $30 \mathrm{mg} / \mathrm{L}$ de formaldeído (item 3.2.1). No entanto, seus parâmetros cinéticos foram muito diferentes dos encontrados nesse trabalho. 
O que é importante ser ressaltado é a ausência de inibição da velocidade de consumo de formaldeído na faixa de concentração estudada. Ao contrário de vários trabalhos que observaram inibição do processo biológico de conversão do formaldeído, este comportamento cinético não prevê qualquer inibição da velocidade global de reação. No entanto, a expressão cinética obtida tem uso restrito para a faixa de concentração aplicada, para a configuração de reator utilizada e para as condições operacionais e ambientais empregadas.

Vários fatores podem ter contribuído para esse resultado positivo em termos de conversão global do formaldeído:

- Por ser um sistema contínuo, acompanhando os demais estudos nesse tipo de sistema, apresentou melhores resultados que os em batelada (ver Tabelas 5.10 e 5.11) quanto à toxicidade na degradação de formaldeído.

- O fato de o RAHLF ser um reator com hidrodinâmica próxima ao modelo de escoamento pistonado pode caracterizar zonas de concentração de biomassa adaptadas às diferentes substâncias presentes ao longo do reator: tóxico, subprodutos de degradação ou ácidos voláteis.

- A espuma de poliuretano utilizada como suporte, além de criar condições de alta retenção de biomassa, pode servir como proteção de toxicidade provocada pelo formaldeído no meio líquido. Devido às resistências à transferência de massa nas fases líquida e sólida, as concentrações que realmente chegam à biomassa imobilizada são menores que as concentrações do tóxico no meio líquido (“bulk”).

- A possibilidade de ter havido a polimerização do formaldeído, com uma rota distinta das apresentadas nos outros trabalhos, pode ter levado a uma toxicidade menor, facilitando a geração de ácidos graxos mais assimiláveis pela biomassa.

- Outro fator importante que pode ter contribuído para o bom desempenho do RAHLF foi a condição inicial do lodo, já adaptado por cerca de um ano à degradação de tóxico, em experimento com fenol.

Utilizando-se a expressão cinética ajustada, somada às características descritas acima e obedecendo-se a faixa de concentração de formaldeído afluente dos estudos cinéticos, é possível se projetar um sistema eficiente para a degradação de formaldeído. Deve-se, também, prover o sistema com os micro e macro nutrientes necessários, além do controlar o pH e a alcalinidade. No Anexo é apresentado um estudo de caso onde se tem um efluente contendo formaldeído, como ilustração da aplicabilidade desses conceitos. 


\section{CONCLUSÕES}

Os resultados obtidos no estudo da degradação de formaldeído em reator anaeróbio horizontal de leito fixo (RAHLF) permitiram as seguintes conclusões:

- O RAHLF é adequado ao tratamento de água residuária contendo formaldeído como única fonte de carbono, apresentando estabilidade ao longo de todo o experimento, até a concentração máxima estudada de 1417 mg HCHO/L, sem efeitos de inibição. As eficiências médias de remoção de formaldeído e DQO foram muito satisfatórias, variando de 92 a 95 \%, respectivamente.

- Embora não tenha sido feito ensaio específico quanto à adsorção de formaldeído pela espuma de poliuretano ou pela biomassa nesse trabalho, a degradação biológica certamente foi a principal forma de remoção de formaldeído, sendo confirmada pelas altas concentrações de metano no biogás e manutenção da concentração de biomassa no reator.

- A espuma de poliuretano favoreceu a retenção de biomassa no reator, alcançando a concentração média de 26,88 g SSV/L, o que possibilitou a obtenção de carga orgânica específica da ordem de 0,086 g HCHO/ g SSV.dia para uma CO aplicada de 2,316 g HCHO/L.dia.

- Constatou-se a presença de ácidos graxos com até cinco átomos de carbono, que pode estar associada à polimerização do formaldeído, muito propícia na ausência de metanol. Por ser um substrato de fácil degradação, o metanol pode ter sido consumido no início do processo, facilitando a polimerização do formaldeído. A presença de muitos organismos semelhantes à Methanosarcina, a partir de concentrações afluentes maiores que $600 \mathrm{mg} / \mathrm{L}$, poderia estar colaborando para o consumo do metanol do substrato. Esta pode ter sido uma das rotas de degradação, divergindo das rotas apresentadas na literatura.

- As análises microbiológicas apresentaram uma biomassa contendo muitas morfologias. Essa diversificação provavelmente contribuiu para a assimilação do formaldeído e seus produtos intermediários de degradação. 
- A rápida adaptação da biomassa ao formaldeído e o seu bom desempenho podem estar associados à sua aclimatação a tóxico, em experimento anterior com fenol.

- O modelo cinético de Monod foi o que melhor representou os dados experimentais, com $r_{\max }^{\text {app }}=2,79 \times 10^{-3}\left( \pm 3,7 \times 10^{-4}\right) \mathrm{mg} \mathrm{HCHO} / \mathrm{mg}$ SSV.h e $\mathrm{K}_{\mathrm{S}}^{\mathrm{app}}=242,8( \pm 114,1) \mathrm{mg} \mathrm{HCHO} / \mathrm{L}$.

- É possível projetar um sistema eficiente para a degradação de formaldeído, utilizando os parâmetros cinéticos encontrados, obedecendo a faixa de concentração afluente de formaldeído dos estudos cinéticos e fornecendo os nutrientes e tamponamento necessário. 


\section{SUGESTÕES}

Com o objetivo de dar continuidade à investigação da degradação de formaldeído em trabalhos futuros, seguem as sugestões:

- Estudar o comportamento da degradação de formaldeído com e sem cosubstrato, em sistemas iguais, para a avaliação e identificação de ácidos e intermediários.

- Analisar a polimerização do formaldeído, identificando a concentração de metanol necessária para que ela não ocorra, levando esses resultados ao processo biológico para avaliação da possível rota através de polímeros.

- Efetuar ensaios com culturas puras, objetivando investigar os microorganismos responsáveis pela degradação de formaldeído a metano.

- Possibilitar a medição do volume de biogás produzido a fim de se estimar a quantidade de formaldeído sendo degradado a metano, dióxido de carbono, hidrogênio e outros intermediários. 


\section{APÊNDICE A}

Estudo de Caso: Utilização de formaldeído no Campus da USP de Ribeirão Preto 


\section{O Campus da USP de Ribeirão Preto}

Muitos problemas ambientais são encontrados em atividades não necessariamente industriais, como é o caso da Universidade de São Paulo. O Campus da USP de Ribeirão Preto, com sua grande produção científica e atividades relacionadas à saúde, acaba sendo também um grande gerador de resíduos.

CAMPOS \& DANIEL (1993) elaboraram um projeto de estação de tratamento de esgoto para o Campus de Ribeirão Preto, que ainda não pôde ser construída. Porém, o município está em vias de implantar a sua estação, cuja cobrança de taxas acarretará num valor razoável a ser cobrado do Campus da USP.

Como subsídio aos levantamentos de dados para esta futura estação, o presente trabalho procurou determinar a influência que os efluentes de laboratórios de anatomia contendo formaldeído poderão ter num processo anaeróbio de tratamento. Optou-se por este efluente tendo em vista o escasso desenvolvimento de pesquisas sobre o assunto, ao contrário da maior parte dos demais efluentes do Campus, como o próprio esgoto sanitário ou outros contaminados por produtos tóxicos e patológicos.

O Campus da USP de Ribeirão Preto possui uma área total de 240 alqueires com $122.000 \mathrm{~m}^{2}$ de área construída (PCARP, 1992). Sua população consiste num somatório de usuários dos serviços prestados à comunidade, dos residentes das 124 casas para funcionários e docentes (cerca de 528 pessoas) e dos alojamentos para estudantes (247 alunos) e dos funcionários, docentes e alunos diretamente ligados à USP (cerca de 6.168).

Tanto o Campus como o Hospital das Clínicas (H.C.) são abastecidos por poços artesianos. Não se tem ainda uma estimativa precisa do volume de água consumido no Campus, apenas a vazão total retirada do poço. Essa vazão não pode ser considerada como vazão de consumo, uma vez que há um grande número de vazamentos na rede. A partir de fins de 1998 iniciou-se a instalação de hidrômetros, o que subsidiará o dimensionamento do futuro sistema de tratamento de esgotos.

A rede de esgotos é razoavelmente simples, descendo por gravidade até o interceptor, unindo-se à rede independente do H.C e posteriormente ao emissário do sistema municipal. Todos os prédios estão ligados a esta rede através de ramais secundários. As águas pluviais têm rede própria ou correm pela superfície.

No Campus estão instaladas seis faculdades, um centro de informática, a prefeitura e suas repartições. O Campus ainda abriga o Centro de Medicina Legal - CEMEL, o Hospital das Clínicas, o Hemocentro, a Biblioteca Central, agências bancárias, correio, casas de apoio 
a pacientes em recuperação, Creche da Carochinha, Escolinha de Artes, além do Restaurante Central e oito cantinas.

Devido à predominância da área biológica, o Campus possui muitos laboratórios onde há o manuseio diário de peças fixadas em formol. Também são utilizados inúmeros produtos químicos, patológicos, tóxicos ou até radioativos que acabam tendo destino final nos esgotos do Campus. São resíduos gerados em laboratórios de pesquisa, biotérios, áreas de saúde, áreas técnicas e operacionais.

\section{Utilização de formaldeído na fixação de peças anatômicas}

O formaldeído é de grande importância para a fixação de tecidos, tanto para trabalhos e aulas de anatomia e patologia, quanto para estudos tanatológicos. Ele impede a proliferação de microorganismos e, portanto, a putrefação, além de impedir o rompimento das paredes dos lisossomos, o que provocaria a autólise da célula pelas enzimas ali contidas (JUNQUEIRA \& CARNEIRO, 1995). A solução mais utilizada para a conservação de cadáveres e peças de anatomia constitui-se de formaldeído em água de torneira, diluído de 8 a $10 \%$. A solução a $10 \%$ resulta numa concentração de aproximadamente 41 g/L de formaldeído e uma DQO de cerca de $62 \mathrm{~g} / \mathrm{L}$.

A Sala de Cubas (Figura A1) do Laboratório Multidisciplinar da FMRP, projetada em 1990, possui 14 cubas medindo 2,00 x 1,10 com 0,65 de profundidade, sendo 12 para depósito e 2 para lavagem das peças. Nas regiões centrais da sala estão as prateleiras de alvenaria para guarda das peças menores em caixas de vidro (Figura A2). O Departamento de Patologia guarda suas peças em caixas de fibro-cimento pintadas com tinta epóxi além de caixas e frascos de vidro (Figura A3). Na Faculdade de Odontologia (FORP), as peças são menores, geralmente referentes à face, e estão armazenadas em caixas e frascos de vidro. No CEMEL, algumas peças de ensino da medicina legal também se encontram fixadas em formol, em tanques plásticos.

O procedimento para preservação de um corpo, de preferência sem lesões e de morte recente, inicia-se com a injeção de solução de formol em água, de $15 \%$ a $25 \%$, nas artérias femurais e nas carótidas, por meio de uma cânula em $\mathrm{T}$ e, posteriormente, nas grandes cavidades, na cavidade craniana e nas massas musculares (CARVALHO, 1950). Desta forma todo o sistema de irrigação sangüínea do corpo receberá a solução, não sendo necessário a retirada de sangue nem de material interior do aparelho digestivo. Com uma sutura no corte 
da injeção, o corpo será armazenado em um dos tanques com a solução de $8 \%$ a 10\%, onde deverá permanecer por um ano antes de ser utilizado nas aulas.

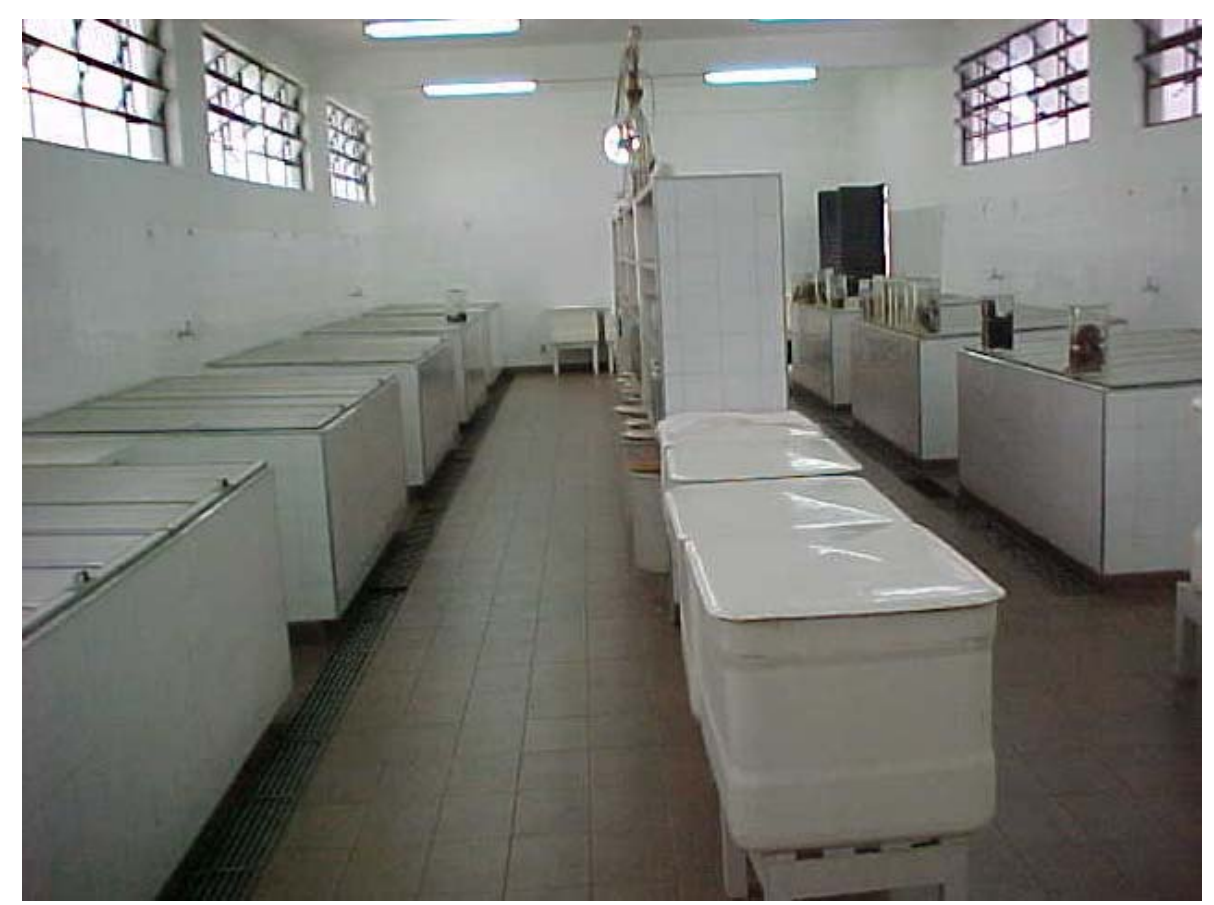

Figura A1 : Vista geral da sala da cubas de cadáveres da FMRP.

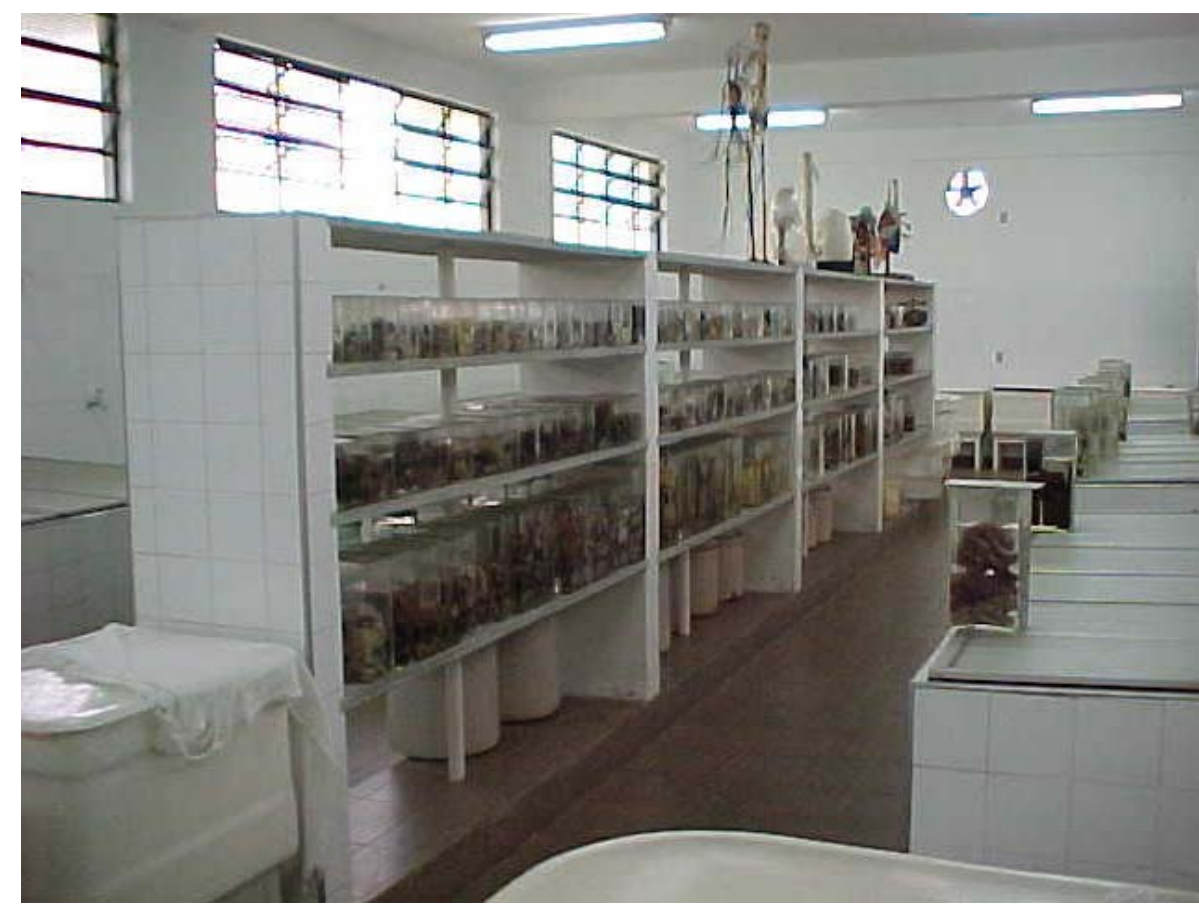

Figura A2: Peças fixadas em formol em caixas de vidro - sala de cubas da FMRP. 


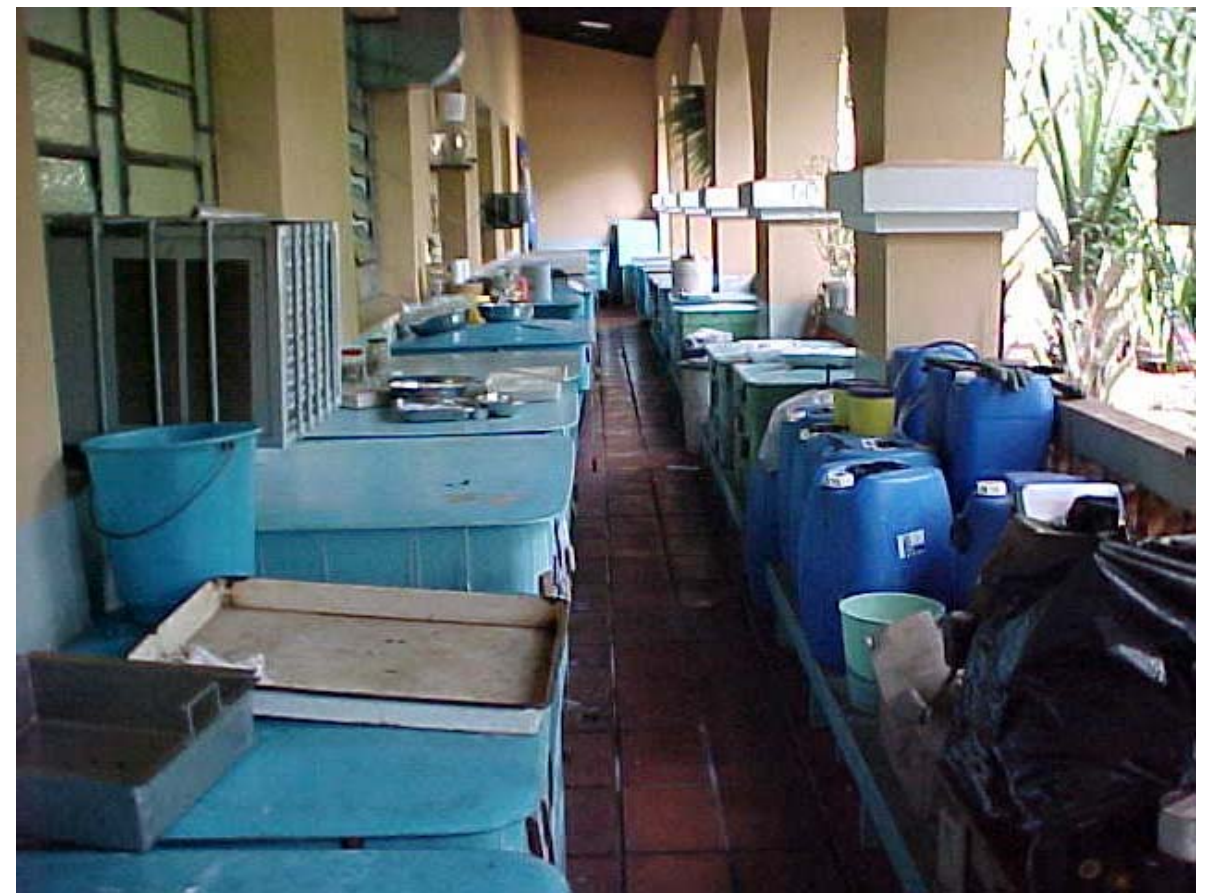

Figura A3: Tanques com peças fixadas em formol - Departamento de Patologia-FMRP.

Para o preparo das peças para as aulas há o constante descarte de formaldeído no esgoto. É preciso que as peças sejam lavadas durante horas para que o excesso de formaldeído seja retirado, minimizando o odor para o seu manuseio. Para se restaurar a cor das peças, para fotografias ou demonstração, deve-se banhá-las em álcool (BAKER, 1969).

O escoamento total das cubas da FMRP é feito somente a cada 2 anos, e dificilmente é escoada mais de uma cuba na mesma época. Para escoá-las, foram instalados registros de fecho rápido, de PVC para não haver corrosão. Durante o escoamento, deve-se abrir os registros de água limpa instalados para provocar a diluição do efluente das cubas, único dispositivo para minimizar a sua toxicidade. Nos demais departamentos não há diluição programada durante o descarte de recipientes ou tanques.

Embora haja muito rigor no preparo e manuseio das peças, não há monitoramento da qualidade da solução de formaldeído através do tempo. Com a abertura das tampas e retirada dos corpos, o formaldeído se volatiliza. Também há diluição do líquido quando são devolvidas as peças lavadas com água. Até que a cuba seja totalmente escoada, ela vai apenas sendo completada com a quantidade necessária de solução. Segundo os técnicos do laboratório multidisciplinar, a indicação de que a solução não está mais com a concentração ideal de formaldeído é o aparecimento de fungos na superfície do líquido. Embora seja uma maneira indireta de indicação, é o único meio usado nos laboratórios para se concluir que a 
solução não está adequada. As peças atacadas por fungos devem ser descartadas por perderem a qualidade.

Como se pode ver, o efluente destes laboratórios não tem uma vazão constante e tampouco é possível se saber com precisão a quantidade de formaldeído presente ao longo de um dado período de tempo.

\section{Caracterização de solução de fixação de peças anatômicas}

Devido aos danos que o formaldeído pode causar ao meio ambiente e a um processo biológico de tratamento de águas residuárias, é importante a caracterização da solução utilizada nos laboratórios para a previsão da diluição necessária.

Para a caracterização do efluente de cubas de cadáveres foi utilizada uma amostra de um tanque contendo corações humanos em solução de formol e água, preparado há cerca de 8 meses, do Departamento de Patologia. Segundo o técnico do laboratório, a concentração inicial foi de $10 \%$ em volume de formol em água de torneira, obtendo-se assim uma concentração de formaldeído de aproximadamente $41 \mathrm{~g} / \mathrm{L}$.

A Tabela A1 apresenta os resultados das análises efetuadas nesse efluente, após cerca de $24 \mathrm{~h}$ da coleta, mantendo-se o recipiente em geladeira de isopor com gelo. A amostra foi coletada do líquido em repouso, cerca de $20 \mathrm{~cm}$ abaixo da superfície, para que não se coletar resíduos do fundo.

A relação DQO/formaldeído foi de 1,56, próximo ao encontrado nos estudos com o RAHLF para soluções de formaldeído em água.

Pode-se observar que houve volatilização e/ou diluição da solução durante os 8 meses de preparo, uma vez que a concentração de formaldeído encontrada foi da ordem de 32,4 g/L, ou seja, em torno de $8 \%$.

Tabela A1: Caracterização do líquido de preservação de cadáveres da FMRP.

\begin{tabular}{lcc}
\hline \multicolumn{1}{c}{ Parâmetro } & Unidade & Valor \\
\hline Formaldeído & $\mathrm{mg} / \mathrm{L}$ & 32362,6 \\
DQO Bruta & $\mathrm{mg} / \mathrm{L}$ & 50783 \\
DQO Filtrada & $\mathrm{mg} / \mathrm{L}$ & 48400 \\
$\mathrm{pH}$ & $\mathrm{mg} / \mathrm{L}$ & 5,1 \\
Sólidos Totais & $\mathrm{mg} / \mathrm{L}$ & 11220 \\
Sólidos Voláteis Totais & $\mathrm{mg} / \mathrm{L}$ & 7840 \\
Sólidos Suspensos Totais & $\mathrm{mg} / \mathrm{L}$ & 57,2 \\
Sólidos Suspensos Voláteis & $\mathrm{mg} / \mathrm{L}$ & 45,2 \\
\hline
\end{tabular}


Segundo BAKER (1969), a solução não poderá ser ácida para não deixar um precipitado pardo nos tecidos, especialmente quando são armazenados por longo tempo. No caso estudado, o pH da solução foi de 5,1, o que indica que seria necessário um tamponamento para se atingir a neutralidade. BAKER (1969) sugere que seja utilizada uma solução tampão com 4 g de monohidrato ácido de fosfato sódico e 6,5 g de fosfato dissódico anidro por litro.

\section{Minimização dos impactos causados pelo descarte de soluções de formaldeído}

O formaldeído é utilizado para fixação de peças nos laboratórios do Campus, tanto por ser uma técnica já tradicional quanto por ter um resultado satisfatório. Sendo assim, a sua substituição provavelmente será difícil, sendo mais viável repensar toda a problemática de seu uso e descarte.

Aplicando-se as três metas básicas da gestão de resíduos em geral, "redução, reutilização e reciclagem”, deveria ser melhor avaliado o processo de controle da qualidade e concentração mínima de formaldeído nos tanques e recipientes. Essa medida poderia reduzir o descarte antecipado ou desnecessário da solução. Deveriam ser desenvolvidas técnicas de filtração ou clarificação das soluções consideradas impróprias, para haver a sua reutilização. O descarte deveria ser restrito a soluções realmente inservíveis. Sendo assim, o volume de formaldeído lançado seria praticamente o das águas de lavagem de peças utilizadas em aulas.

O descarte de formaldeído no meio ambiente deverá ser feito em concentrações muito baixas, como já foi citado. No caso dessa substância atingir um sistema de tratamento biológico de águas residuárias, poderá comprometer a biomassa pelo seu poder bactericida. Embora ainda não se tenha um consenso sobre a concentração de formaldeído ideal para sistemas de tratamento aeróbios e anaeróbios, em nenhum dos estudos publicados foi obtido sucesso com concentrações superiores a $3 \mathrm{~g} / \mathrm{L}$. Na maioria dos casos, os sistemas toleraram concentrações inferiores a $1 \mathrm{~g} / \mathrm{L}$. Pode-se concluir que será necessária uma diluição de cerca de 50 vezes, no caso de escoamento de tanques com concentração em torno de 10 \%.

No sistema atual de diluição, durante o escoamento das cubas do Laboratório Multidisciplinar, é utilizada água potável, com diluição de 1:1. Em quase todos os laboratórios do Campus há destiladores que também utilizam água potável para resfriamento. O aproveitamento dessa água de resfriamento para a diluição dos efluentes com formaldeído poderia minimizar esse desperdício. Para isso, seria necessária a instalação de uma rede 
especial de captação dessa água e de tanques para ser feita a diluição dos efluentes com formaldeído.

\section{Instalação de RAHLF para tratamento de solução de formaldeído}

Como já foi comentado, o descarte de efluentes contendo formaldeído no Campus, não obedece a nenhum critério específico, causando concentrações variáveis ao longo do dia, da semana e do ano. No período de férias escolares, não são lavadas peças para o preparo de aulas, e muitos laboratórios diminuem a sua rotina de trabalho. Esses fatores influenciam muito a caracterização das vazões desse efluente.

Nos estudos com o RAHLF, onde se empregou o formaldeído como fonte única de carbono, a concentração média máxima de formaldeído aplicada foi de 1416,8 mg/L, não havendo queda na produção de metano, nem na eficiência de remoção de formaldeído e de DQO.

A princípio, algumas vantagens podem ser vistas em se tratar os efluentes com formaldeído do Campus numa estação central: a diluição será feita pelo restante do esgoto do Campus, muitos nutrientes serão fornecidos por esse esgoto e o trabalho de monitoramento será reduzido a uma única estação. No entanto, devido à instabilidade da concentração de formaldeído lançada, o sistema corre o risco de receber uma sobrecarga que poderá prejudicar o tratamento de toda a rede. Ao mesmo tempo, os estudos sugerem que águas residuárias complexas diminuem a concentração máxima de formaldeído assimilável pelo sistema.

Sendo assim, a instalação de um sistema de tratamento específico para os efluentes contendo formaldeído torna-se uma alternativa justificável. Com os resultados bastante satisfatórios de degradação de formaldeído no RAHLF, esse reator poderia ser utilizado após um tanque de diluição com água de resfriamento de destiladores, dos próprios laboratórios da faculdade. Os nutrientes necessários e a solução tampão deverão ser fornecidos por um dispositivo automático. Por se tratar de substrato tóxico, o sistema poderá estar sujeito a instabilidades. Porém, com uma fonte única de carbono e controle dos demais parâmetros, a identificação e a solução dos problemas poderá ser menos complexa.

A Figura A4 simboliza esquematicamente um sistema para tratamento de efluente de cuba de cadáveres fixados em formol. O objetivo é analisar uma situação crítica do escoamento de uma cuba com $2 \mathrm{~m}^{3}$ de fluido, com concentração aproximada de $41 \mathrm{~g} / \mathrm{L}$ de formaldeído (solução a 10 \% de HCHO). Devido ao dispositivo de diluição 1:1 com água de 
torneira, instalado ao lado das cubas, a concentração que será lançada ao tanque de equalização será de aproximadamente 20,5 g/L de formaldeído.

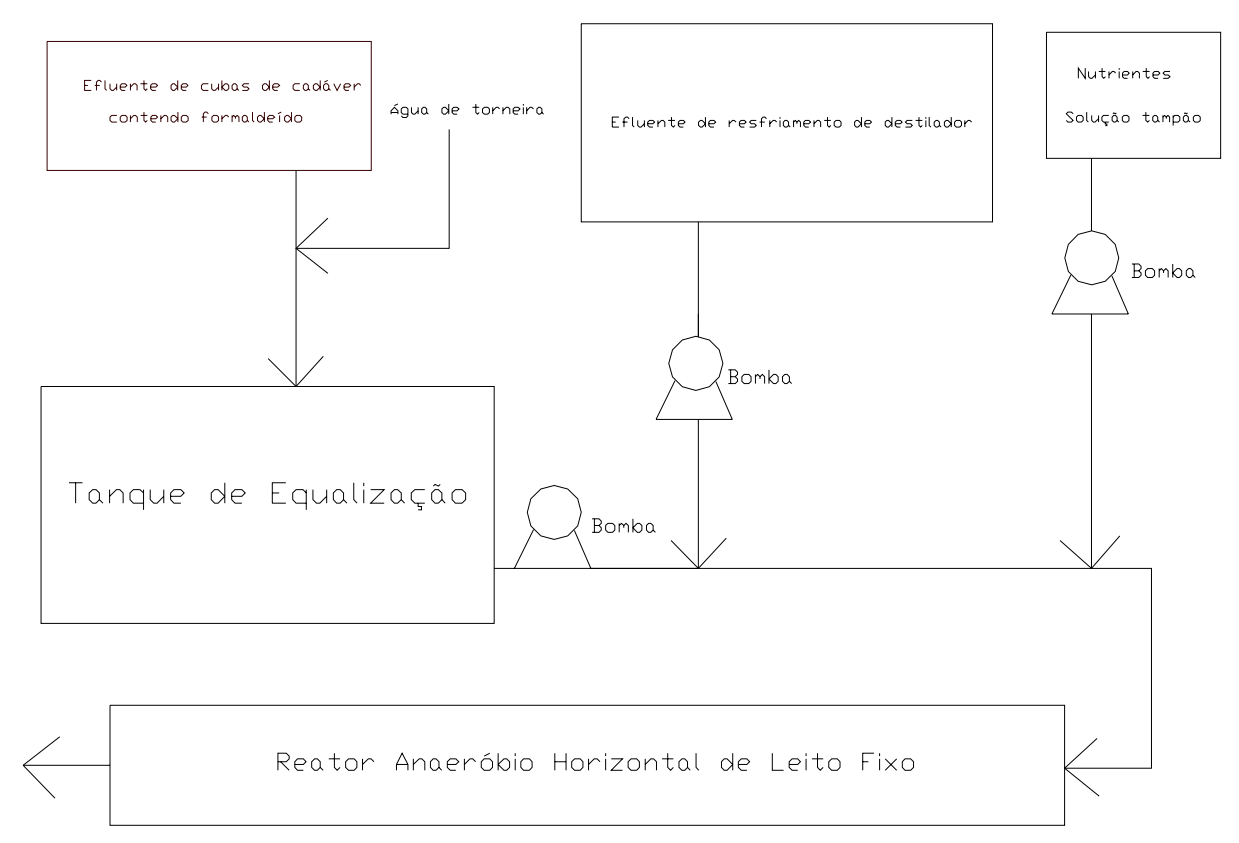

Figura A4: Representação esquemática de sistema de tratamento de efluente de fixação de cadáveres, à base de formaldeído, com RAHLF.

A diluição final do efluente do tanque de equalização será feita empregando-se água de resfriamento de destiladores (diluição 1:20), para se atingir a concentração de aproximadamente $1025 \mathrm{mg} / \mathrm{L}$ de formaldeído. Esse efluente previamente diluído, somado aos nutrientes e à solução tampão, será o afluente do RAHLF. Considerando-se que o conteúdo de uma cuba despejada deva ser tratado em um mês, a vazão será de $80 \mathrm{~m}^{3} / \mathrm{mês}$ (diluição 1:20) ou 2,7 m²/dia, ou ainda, 111,1 L/h. Deve ser considerado também que, além do volume da cuba haverá também o volume diário de água de lavagem do chão da sala, a ser tratado. Essa situação pode ser considerada como condição de pico. O reator operará o ano todo continuamente, tratando efluente dos tanques de cadáveres, bem como a água de lavagem da sala de cubas.

Dois critérios foram utilizados para se projetar o RAHLF para tratamento das águas contendo formaldeído.

- Critério I: Fixando TDH de acordo com o ótimo nos experimentos em bancada.

Fixando-se o TDH em 8 horas, com base no volume líquido do sistema, o reator deverá ter um volume líquido de escoamento de, aproximadamente, 900 litros. Isso implica 
num volume total de reator de 2250 litros, considerando porosidade do leito de espuma de $40 \%$.

Estipulando a mesma velocidade superficial de líquido de $0,1 \mathrm{~cm} / \mathrm{s}(360 \mathrm{~cm} / \mathrm{h})$, conforme adotado por Zaiat et al. (2000) no projeto de unidade de RAHLF piloto, a área seccional total do tubo deverá ser $771,5 \mathrm{~cm} 2$ e, conseqüentemente, o diâmetro do tubo deverá ser de, aproximadamente, $30 \mathrm{~cm}$.

Dessa forma, o reator deveria ter comprimento total de, aproximadamente, 32 metros, podendo ser construído em dez módulos de, aproximadamente, 3 metros para facilitar a operação e manutenção.

A eficiência esperada neste sistema é a mesma obtida nos ensaios em laboratório, para a concentração de projeto.

A adoção de velocidade superficial maior que a avaliada em laboratório provavelmente superdimensiona a unidade, pois se espera menor resistência à transferência de massa na fase líquida à medida que se aumenta a velocidade superficial. Em conseqüência, a velocidade global de conversão seria maior quanto maior a velocidade superficial. Nesse caso, a adoção de velocidade superficial de líquido alta representa critério de segurança para o projeto.

\section{- Critério II: Utilizando os parâmetros cinéticos}

O reator também pode ser projetado utilizando-se o modelo cinético ajustado com as constantes determinadas, considerando o reator como tubular ideal (Nardi et al., 1999). Como já foi ressaltado, os parâmetros cinéticos são aparentes e valem apenas para as condições operacionais e ambientais do experimento em bancada. No entanto, como exercício de aplicação, o modelo cinético obtido pode servir como uma primeira aproximação ao projeto do reator.

O balanço de massa em reator tubular ideal resulta em:

$\mathrm{TDH}=-\int_{\mathrm{C}_{\mathrm{Fo}}}^{\mathrm{C}_{\mathrm{F}}} \frac{\mathrm{dC}_{\mathrm{F}}}{\left(\mathrm{R}_{\mathrm{obs}}\right)}$

$\mathrm{C}_{\mathrm{Fo}}$ é a concentração afluente de formaldeído.

Sendo:

$$
\mathrm{R}_{\text {obs }}=\mathrm{R}_{\max }^{\mathrm{app}} \frac{\mathrm{C}_{\mathrm{F}}}{\mathrm{K}_{\mathrm{S}}^{\mathrm{app}}+\mathrm{C}_{\mathrm{F}}}
$$


Para o caso estudado:

$\mathrm{R}_{\max }^{\mathrm{app}}=187,5 \mathrm{mg} \mathrm{HCHO} /$.L.h (velocidade máxima de consumo de formaldeído)

$\mathrm{K}_{\mathrm{S}}^{\mathrm{app}}=242,8 \mathrm{mg} \mathrm{HCHO} / \mathrm{L}$

Integrando a expressão de balanço de massa no reator, chega-se a:

$\mathrm{TDH}=\frac{\mathrm{K}_{\mathrm{S}}^{\text {app }}}{\mathrm{R}_{\text {max }}^{\text {app }}} \ln \left(\frac{\mathrm{C}_{\mathrm{Fo}}}{\mathrm{C}_{\mathrm{F}}}\right)+\frac{1}{\mathrm{R}_{\text {max }}^{\text {app }}}\left(\mathrm{C}_{\mathrm{Fo}}-\mathrm{C}_{\mathrm{F}}\right)$

Considerando a concentração afluente de formaldeído (CFo igual a 1025 mg/L após diluição e estipulando uma eficiência de $99 \%$ ao tratamento, isto é, CF igual a $5 \mathrm{mg} / \mathrm{L}$, aproximadamente, o TDH obtido que deve ser aplicado ao reator deverá ser de 12,3 horas. Considerando a vazão de 111, 1 L/h, o volume do reator total deveria ser de 3424,7 litros para porosidade de leito de $40 \%$.

Dessa forma, o reator projetado pelo critério cinético é cerca de $50 \%$ maior que o reator projetado utilizando como critério o TDH experimental em escala de bancada. 


\section{REFERÊNCIAS BIBLIOGRÁFICAS}

ADROER, N.; CASAS, C.; DE MAS, C.; SOLÁ, C. (1990). Mechanisms of formaldehyde biodegradation by Pseudomonas putida. Applied Microbiology Biotechnology, v.33, p.217-20.

ALLINGER, N.L.; CAVA, M.P.; DE JONGH, D.C.; STEVENS, C.L. (1978). Química orgânica. 2.ed. Rio de Janeiro, Editora Guanabara Dois S.A.

ANGELIDAKI, I.; PETERSEN, S.P.; AHRING, B. K. (1990). Effects of lipids on thermophilic anaerobic digestion and reduction of lipid inhibition upon addition of bentonite. Applied Microbiology Biotechnology, v. 33, p. 469 - 72.

APHA, AWWA, WPCF (1998). Standard Methods for the Examination of Water and Wastewater. 20th ed. American Public Health Association / American Water Works Association / Water Environment Federation, Washington, DC, USA.

ASSUMPÇÃO, R.M.V., MORITA, T. (1968). Manual de soluções, reagentes e solventes. São Paulo, Ed.Edgard Blücher Ltda.

BAILEY, B.W.; RANKIN, J.M. (1971). New Spectrophotometric Method for Determination of Formaldehyde. Analytical Chemistry, v. 43, n.6, p. 782-84, May.

BAILEY, J.E.; OLLIS, D.F. (1986). Biochemical Engineering Fundamentals. 2 ed. New York, McGraw-Hill.

BAKER, R.D. (1969). Técnicas de necropsia. México: Editorial Interamericana S.A

BHATTACHARYA, S.K.; PARKIN, G.F. (1988). Fate and effect of methylene chloride and formaldehyde in methane fermentation systems. Journal WPCF., v. 60, n. 4, p. 531-36, Apr.

BOLAÑOS, R.M.L. (2001). Tratamento de fenol em reator anaeróbio horizontal de leito fixo (RAHLF) sob condições mesofílicas. São Carlos. Tese (Doutorado) - Escola de Engenharia de São Carlos, Universidade de São Paulo.

BONASTRE, N.; DE MAS, C.; SOLÁ, C. (1985). Vavilin equation in kinetic modeling of formaldehyde biodegradation. Biotechnology and Bioengineering, v. 28, p.616-19.

BOONE, D.R.; MAH, R.A. (1984). Family II. Methanosarcinaceae. In: Bergeys’s Manual of Systematic Bacteriology.

BORGHANS, A.J.M.L.; VAN DRIEL, A. (1988). Application of the biothane ${ }^{\circledR}$ UASB reactor to a chemical wastewater, containing phenol and formaldehyde. In: 
INTERNATIONAL SYMPOSIUM ON ANAEROBIC DIGESTION, 5., Bologna, IT, 1988. Atas. Bologna Advances in Water Pollution Control, Pergamon Press.

CAMPOS, J.R.; DANIEL, L.A. (1993). Projeto Hidráulico do Sistema de Tratamento de Águas Residuárias do Campus da Universidade de São Paulo em Ribeirão Preto. São Carlos. Cópias heliográficas e memorial descritivo.

CARVALHO, H.V. (1950). Manual de técnica tanatológica. São Paulo: Typ. Rossolillo.

CASTEEL, S.W.; VERNON, R.J., BAILEY E.M. (1987). Formaldehyde: Toxicology and Hazards. Veterinary and Human Toxicology, v. 29, p. 31-3, Febr.

COLEMAN, R.; KOGAN, I. (1998). An improved low-formaldehyde embalming fluid to preserve cadavers for anatomy teaching. Journal of Anatomy, v. 192, p. 443-46.

CONAWAY, C.C.; WHYSNER, J.; VERNA, L.K.; WILLIAMS, G.M. (1996). Formaldehyde mechanistic data and risk assessment: endogenous protection from DNA adduct formation. Pharmacol.Ther., v.71, n.1/2, p.29-55.

DAMIANOVIC, M.H.R.Z. (1997). Degradação de pentaclorofenol (PCP) em reatores anaeróbios horizontais de leito fixo (RAHLF). São Carlos. Tese (Doutorado) - Escola de Engenharia de São Carlos, Universidade de São Paulo.

EDWARDS, F.G.; EGEMEN, E.; BRENNAN, R.; NIRMALAKHANDAN, N. (1999). Ranking of toxics release inventory chemicals using a level III fugacity model and toxicity. Water Science and technology, v. 39, n.10-11, p. 83-90.

ESCALANTE-SEMERENA, J.C.; WOLFE, R.S. (1984). Formaldehyde oxidation and methanogenesis. Journal of Bacteriology, v.158, n.2, p.721-6, May.

FELTRE, R.; YOSHINAGA, T. (1977). Química orgânica. São Paulo: Editora Moderna.

FORESTI, E.; ZAIAT,M.; CABRAL, A.K.A.; DEL NERY, V. (1995). Horizontal-flow anaerobic immobilized sludge (HAIS) reactor for paper industry wastewater treatment. Brazilian Journal of Chemical Engineering, v.12, p. 235-9.

GONZALEZ-GIL, G.; KLEEREBEZEM, R.; VAN AELST, A.; ZOUTBERG, G.R.; VERSPRILLE, A.I.; LETTINGA, G. (1999). Toxicity Effects of Formaldehyde on Methanol Degrading Sludge and its Anaerobic Conversion in Biobed Expanded Granular Sludge Bed (EGSB) Reactors. Water Science and Technology, v. 40, n.8, p. 195-202.

GONZALEZ-GIL, G. (2000). Conversion of Methanotrophic Substrates in Anaerobic Reactors, Metals, Mass Transfer and Toxicity. Wageningen, 157p. Tese (Doutorado) Wageningen University, The Netherlands.

GOTVAJN, A.Z.; ZAGORC-KONCAN, J. (1998). Whole effluent and single substances approach: a tool for hazardous wastewater management. Water Science and Technology, v.37, n.8, p.219-27.

GRAFSTROM, R.C.; CURREN, R.D.; HARRIS, C.C. (1985). Genotoxicity of Formaldehyde in Cultured Human Bronchial Fibroblasts. Science, v. 228, p. 89-91, Apr. 
HICKEY, R.F.; VANDERWIELEN, J.; SWITZENBAUM, M.S. (1987). The effects of organic toxicants on methane production and hydrogen gas levels during the anaerobic digestion of waste activated sludge. Water Research, v. 21, n.11, p. 1417-27.

JUNQUEIRA, L.C.; CARNEIRO, J. (1995). Histologia básica. 8. ed. Rio de Janeiro, Editora Guanabara Koogan S.A.

LEONOVA, V.E.; ABRAMOV, A.V.; KARPUKHIN, V.F. (1985). Kinetics of formaldehyde biodegradation. Microbiology, v. 54, p.124-28.

LU, Z.; HEGEMANN, W. (1998). Anaerobic toxicity and biodegradation of formaldehyde in batch cultures. Water Research, v. 32, n. 1, p. 209-15, Apr.

MSDS - Material Safety Data Sheet (2000). F5522 (Formaldehyde), Mallinckrodt/J.T. Baker, Phillipsburg, NJ, USA.

MSDS - Material Safety Data Sheet (2000-a). p-phenylenediamine dihydrochloride, Mallinckrodt/J.T. Baker, Phillipsburg, NJ, USA.

MINGOIA, Q. (1967). Química farmacêutica. São Paulo: Ed.Universidade de São Paulo.

NARDI, I. R.; ZAIAT, M.; FORESTI, E. (1999). Influence of the Tracer Characteristics on Hydrodynamic Models of Packed-Bed Bioreactors. Bioprocess Engineering, v.21, n. 5, p. 469-76.

NARDI, I. R.; ZAIAT, M.; FORESTI, E. (2000). Degradação de BTEX em reator anaeróbio horizontal de leito fixo na presença de diferentes aceptores de elétrons. In: Oficina e Seminário Latino-Americano de Digestão Anaeróbia, 6, Recife - PE, 2000. Anais. Recife, Editora Universitária da UFPE. v.2, p.151-4.

NOGUEIRA, M.I.; BARBIERI, C.; VIEIRA, R.; MARQUES, E.R.; MORENO, J.E.H. (1997). A Practical Device for Histological Fixative Procedures that Limits Formaldehyde Deleterious Effects in Laboratory Environments. Journal of Neuroscience Methods, v. 72, p. 65-70.

OMIL, F.; MÉNDEZ, D.; VIDAL, G.; MÉNDEZ, R.; LEMA, J.M. (1999). Biodegradation of formaldehyde under anaerobic conditions. Enzyme and Microbial Technology, v. 24, p. 255-62.

PARKIN, G.F; SPEECE, R.E.; YANG, C.H.J.; KOCHER, W.M. (1983). Response of methane fermentation systems to industrial toxicants. Journal WPCF, v.55, n.1, p.44-53, Jan.

PARKIN, G.F.; SPEECE, R.E. (1983). Attached versus suspended growth anaerobic reactors: response to toxic substrates. Water Science and Technology, v. 15, p. 261-89.

PAVLOV, B.; TÉRENTIEV, A. (1967). Chimie organique. Moscou, Éditions Mir.

PCARP (Assessoria de Comunicação Social e Imprensa) (1992). PCARP. São Paulo: Coordenadoria de Comunicação Social da USP. 
PERUZZO, T.M.; CANTO, E.L. (1998). Química: na abordagem do cotidiano. São Paulo: Editora Moderna.

QU, M.; BHATTACHARYA, S.K. (1997). Toxicity and biodegradation of formaldehyde in anaerobic methanogenic culture. Biotechnology and Bioengineering, v. 55, n.5, p. 727-36, Sept.

RIPLEY, L.E; BOYLE, W.C.; CONVERSE, J.C. (1986) Improved Alkalimetric Monitoring for Anaerobic Digestion of High-Strength Wastes. Journal WPCF, v. 58, p. 406-11.

SARTI, A.; VIEIRA, L.G.T.; FORESTI, E.; ZAIAT, M. (2001). Influence of the liquidphase mass transfer on the performance of a packed-bed bioreactor for wastewater treatment. Bioresource Technology, v.78, n.3, p.231-8.

SHARMA, S.; RAMAKRISHNA, C.; DESAI, J.D., BHATT, N.M. (1994). Anaerobic biodegradation of a petrochemical waste-water using biomass support particles. Applied Microbiology and Biotechnology, v. 40, p. 768-71.

SILVEIRA, B.I. DA (1996) Cinética química das reações homogêneas. Editora Edgard Blücher, São Paulo.

SPEECE, R.E. (1996). Anaerobic Biotechnology for Industrial Wastewaters. Nashville, Tennessee: Archae Press.

TAKESUE, S.; ISHIBASHI, K.; WATANABE, K.; YAMASHITA, M.; KOJIMA, M. (1983). Decomposition of formaldehyde in hospital wastewater with slaked lime. Journal of Agricultural Chemical Society of Japan, v. 57, p. 659-61.

TODINI, O.; HULSHOFF POL, L. (1992). Anaerobic degradation of benzaldehyde in methanogenic granular sludge: the influence of additional substrates. Applied Microbiology and Biotechnology, v.38, p.417-20.

VIDAL, G.; JIANG, Z.P.; OMIL, F.; THALASSO, F.; MÉNDEZ, R.; LEMA, J.M. (1999). Continuous anaerobic treatment of wastewaters containing formaldehyde and urea. Bioresource Technology, v. 70, p. 283-91, Dec.

VOGEL, A.I. (1971). Química orgânica. 3.ed. Rio de Janeiro: Ao Livro Técnico S.A.

WALDEN, P.(1972). Geschichte der organichen Chemie seit 1880. Reprint 1972. Berlin, Springer.

ZAIAT, M; CABRAL, A.K.A.; FORESTI, E. (1994). Reator anaeróbio de leito fixo para tratamento de águas residuárias: concepção e avaliação preliminar de desempenho. Revista Brasileira de Engenharia - Caderno de Engenharia Química, v.11, p.33-42.

ZAIAT, M. (1996). Desenvolvimento de Reator Anaeróbio Horizontal de Leito Fixo (RAHLF) para tratamento de águas residuárias. São Carlos, SP. Tese (Doutorado)- Escola de Engenharia de São Carlos, Universidade de São Paulo.

ZAIAT, M.; FORESTI, E. (1997). Method for Estimating the Kinetics of Substrate Degradation in Horizontal-Flow Anaerobic Immobilized Sludge (HAIS) Reactor. Biotechnology Techniques, v.5, n.11, p.315-8. 
ZAIAT, M.; VIEIRA, L.G.T.; CABRAL, A.K.A.; DE NARDI, I.R.; VELA, F.J.; FORESTI, E. (1997). Rational basis for designing horizontal-flow anaerobic immobilized sludge (HAIS) reactor for wastewater treatment. Brazilian Journal of Chemical Engineering, v. 14, n.1, p. 01-08, Mar.

ZAIAT, M.; PASSIG, F.H.; FORESTI, E. (2000). A mathematical model and criteria for designing horizontal-flow anaerobic immobilized biomass reactors for wastewater treatment. Bioresource Technology, v.71, p.235-43.

ZEHNDER, A.J.B. (1984). Genus III. Methanotrix. In: Bergeys's Manual of Systematic Bacteriology.

ZOUTBERG, G.R; DE BEEN, P. (1997). The Biobed ${ }^{\circledR}$ EGSB (Expanded Granular Sludge Bed) system covers shortcomings of the up flow anaerobic sludge blanket reactor in the chemical industry. Water Science and Technology, v. 35, n. 10, p. 183-88. 